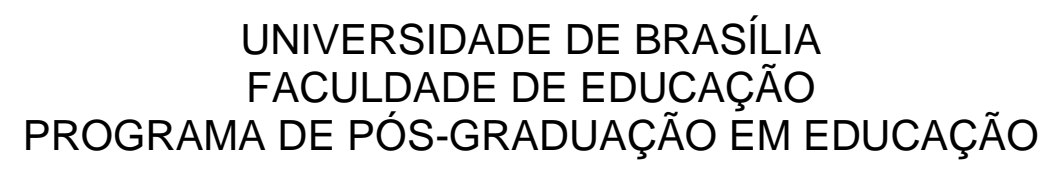

LUCAS LOPES DE SANTANA

SUBPROJETO PIBID DE FÍSICA NA UnB: IMPLEMENTAÇÃO DE UMA POLÍTICA PÚBLICA DE FORMAÇÃO DE PROFESSORES 


\section{LUCAS LOPES DE SANTANA}

SUBPROJETO PIBID DE FÍSICA NA UnB: IMPLEMENTAÇÃO DE UMA POLÍTICA PÚBLICA DE FORMAÇÃO DE PROFESSORES

Dissertação apresentada ao Programa de Pós-Graduação em Educação - PPGE da Faculdade de Educação da Universidade de Brasília - FE/UnB como requisito para a obtenção do título de Mestre em Educação pela linha de pesquisa "Profissão Docente, Currículo e Avaliação", eixo de interesse "Profissão e Desenvolvimento Profissional Docente".

Orientadora: Prof. ${ }^{\text {a }}$ Dr. a Kátia Augusta Curado Pinheiro Cordeiro da Silva 


\title{
SUBPROJETO PIBID DE FÍSICA NA UnB: IMPLEMENTAÇÃO DE UMA POLÍTICA PÚBLICA DE FORMAÇÃO DE PROFESSORES
}

Dissertação apresentada ao Programa de Pós-Graduação em Educação - PPGE da Faculdade de Educação da Universidade de Brasília - FE/UnB como requisito para a obtenção do título de Mestre em Educação.

\section{COMISSÃO EXAMINADORA:}

Prof. ${ }^{\text {D }}$. ${ }^{\text {a }}$ Kátia Augusta Curado Pinheiro Cordeiro da Silva

Faculdade de Educação da Universidade de Brasília Presidente

\author{
Prof. Dr. Ricardo Gauche \\ Instituto de Química da Universidade de Brasília \\ Examinador externo
}

Prof. ${ }^{\text {a }}$ Dr. ${ }^{\text {a }}$ Cleide Maria Quevedo Quixadá Viana

Faculdade de Educação da Universidade de Brasília

Examinadora interna

Prof. ${ }^{\text {a }}$ Dr.. - Shirleide Pereira da Silva Cruz

Faculdade de Educação da Universidade de Brasília

Examinadora suplente 
A Cleide Vilela e Lila Lopes. Sem vocês, nada disto seria possível. 


\section{AGRADECIMENTOS}

Nesse período introdutório ao fazer científico chamado mestrado, escutei muitas vezes que a academia é um caminho para a solidão. Isso só se torna verdade se eu desconsiderar a fundamental influência de tantas ilustres personalidades sobre mim durante esses 30 meses. Digo 30 meses porque não comecei essa trajetória no primeiro dia de aulas, mas no período de preparação para a seleção.

Em primeiro lugar, agradeço à prof. a Mônica Molina, cujo incentivo foi fundamental para que eu me interessasse pelos estudos de Educação.

Minha orientadora, Kátia Augusta Curado Pinheiro Cordeiro da Silva foi a grande responsável pela condução deste trabalho. Com ela, aprendi a seguir a trilha da pesquisa. Seu incentivo à produtividade levou a mim e aos demais colegas a tomar contato com a comunidade acadêmica e a trocar experiências. O resultado foi um crescimento - para além de acadêmico - pessoal. Levo estes dois anos de aprendizado sobre método para toda minha vida.

Os amigos Diogo Torres Osvaldo Assis, Daniel Nunes foram companheiros de estrada e de vivência acadêmica na UnB. Sem estes parceiros, eu não sairia do lugar!

À prof. ${ }^{\text {a }}$ Cleide Quixadá e ao prof. Ricardo Gauche, apresento minha profunda gratidão. O que escapou aos olhos de todos, foi captado e apontado com argúcia pela dupla na defesa do projeto.

Tive a alegria de contar com a coordenação de área do subprojeto Pibid Física UnB, cuja prestatividade foi nada menos que fundamental.

Nossos familiares devotaram pedaços de suas vidas para garantir minutos preciosos de leitura e escrita. Ana Cleide e Julieta do Carmo oram essenciais para a escrita de algumas dessas páginas. Já Francinete e Marivaldo de Santana, meus pais, conseguiram me pôr no lugar quando escorregava. Muita experiência.

Neste percurso, pude contar com o incentivo de meus colegas de trabalho, os quais reconhecem a importância da produção de saber a respeito de programas públicos. Enildo Arnaud, Ítalo Henrique Alves e Weder Matias merecem mais do que esta nota de retribuição.

Tanta força recebida me fez maior. 


\section{RESUMO}

O tema deste trabalho é a política pública de educação conhecida como Programa Institucional de Bolsa de Iniciação à Docência (Pibid). Usando o método do estudo de caso, esta pesquisa de natureza qualitativa discute se o subprojeto Pibid da licenciatura em Física, implementado pela Universidade de Brasília (UnB), implementa os objetivos da política pública em questão. A seguinte pergunta norteia esta investigação: no ano de 2014, o subprojeto Pibid Física UnB realizou com sucesso a proposta de formação docente do Programa Institucional de Bolsa de Iniciação à Docência? O objetivo geral da pesquisa é analisar objetivos, metodologias, ações, forma de relação entre universidade e escola e resultados esperados, presentes no relatório de atividades do subprojeto Pibid Física UnB relativo ao ano de 2014, para revelar convergências e divergências em relação à proposta de formação de professores do Programa Institucional de Bolsa de Iniciação à Docência. A conclusão aponta elementos para defender que o subprojeto implementa com sucesso a proposta do Pibid; contudo, a metodologia do subprojeto demanda definição mais precisa com relação à aprendizagem colaborativa; e suas ações devem ser refletir o planejamento. A reflexão sugere que o Pibid reveja seus objetivos, uma vez que a valorização docente não pode ser alcançada pelos projetos, pois envolve principalmente uma política salarial digna para a carreira.

Palavras-chave: Capes. Educação Básica. Formação de Professores. Licenciatura. Pibid. Política pública.

\section{ABSTRACT}

The theme of this work is the educational public policy known as Institutional Scholarship Program for Introduction to Teaching (Pibid, in Portuguese). This is a case study on the adhesion of the subproject Pibid of Physics implemented by the University of Brasília (UnB) to the objectives of the public policy in question. This research seeks to answer the following question: what are the convergent and divergent points between the actions taken by the subproject Pibid Physics UnB in the year 2014 and Pibid expectations expressed in its regulations? The objective of this research is to analyze the activities report of the subproject Pibid Physics UnB on 2014 in order to reveal whether the subproject has adherence to the public program in the following aspects: objectives, methodology, actions, nature of relationship between University and school and expected results. The conclusion presents elements to affirm that the subproject has adherence to the program, and successfully implements the Pibid proposal; however, methodology and actions need some improvement by the subproject. The reflection herein suggests that Pibid itself needs to review its objectives as well, because teacher appreciation cannot be achieved by the funded projects, since it mainly demands a dignified wage policy.

Keywords: Capes. Elementary education. Teacher education. Pibid. Public policy. 


\section{LISTA DE FIGURAS}

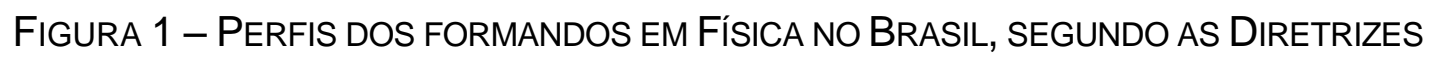

CURRICULARES NACIONAIS

FIGURA 2 - NÚMERO DE INGRESSOS EM CURSOS DE LICENCIATURA E BACHARELADO E TAXA DE CRESCIMENTO ANUAL NO NÚMERO DE INGRESSOS NO PERÍODO DE 2002-2007 (ANO DE

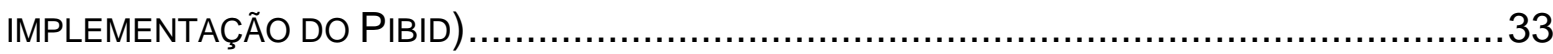

FIGURA 3 - NÚMERO DE CONCLUINTES EM CURSOS DE LICENCIATURA E BACHARELADO E TAXA DE CRESCIMENTO ANUAL NO NÚMERO DE CONCLUINTES NO PERÍODO DE 2002-2007 (ANO DE IMPLEMENTAÇÃO DO PIBID) 33

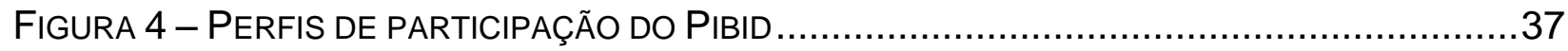

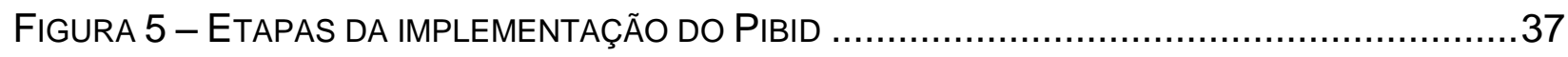

FIGURA 6 - ORGANIZAÇÃO HIERÁRQUICA DOS STAKEHOLDERS DO PIBID ..............................40

FIGURA 7 - QUANTIDADE DE ARTIGOS SOBRE O PIBID, POR CATEGORIA, POR PERIÓDICO, PUBLICADOS DE 2009 A 2013 EM PERIÓDICOS DE CONCEITOS QUALIS A1 A B2

FIGURA 8 - QUANTIDADE DE ARTIGOS SOBRE O PIBID, POR CATEGORIA, POR ANO, PUBLICADOS DE 2009 A 2013 EM PERIÓDICOS DE CONCEITOS QUALIS A1 A B2

FIGURA 9 - QUANTIDADE DE DISSERTAÇÕES E TESES SOBRE O PIBID, POR CATEGORIA, POR ANO, DEFENDIDAS DE 2009 A 2013

FIGURA 10 - LOCALIZAÇÃO DAS ESCOLAS PARTICIPANTES DO SUBPROJETO PIBID FíSICA UNB83

FiguRA 11 - RELAÇÃo dE ESCOLAS PARTICIPANTES do SUBPROJETO PIBID FÍSICA UNB .......97

FIGURA 12 - RESULTADOS DO IDEB - OBSERVADO E METAS .........................................97 


\section{LISTA DE SIGLAS}

AC Aprendizagem colaborativa

Anped Associação Nacional de Pesquisa e Pós-Graduação em Educação

CA Coordenador de área do Pibid

Capes Coordenação de Aperfeiçoamento de Pessoal de Nível Superior

CED Centro de Educação

Cefet Centros Federais de Educação Tecnológica

CEM Centro de Ensino Médio

Cemab Centro de Ensino Médio Asa Branca

CG Coordenador de área de gestão de processos educacionais do Pibid

$\mathrm{Cl} \quad$ Coordenador institucional do Pibid

CNE Conselho Nacional de Educação

Conae Conferência Nacional de Educação

Coneb Conferência Nacional de Educação Básica

DF Distrito Federal

Enem Exame Nacional do Ensino Médio

Fonalifes Fórum Nacional das Licenciaturas dos Institutos Federais

FURG Universidade Federal do Rio Grande

Ibict Instituto Brasileiro de Informação em Ciência e Tecnologia

ID Bolsista de iniciação à docência

Ideb Índice de Desenvolvimento da Educação Básica

IES Instituição de educação superior

Inep Instituto Nacional de Estudos e Pesquisas Educacionais Anísio Teixeira

Parfor Plano Nacional de Formação de Professores da Educação Básica

Pibid Programa Institucional de Bolsa de Iniciação à Docência

PNE Plano Nacional de Educação

Prodocência Programa de Consolidação das Licenciaturas

Prouni Programa Universidade para Todos

PUC-RIO Pontifícia Universidade Católica do Rio de Janeiro

PUC-RS Pontifícia Universidade Católica do Rio Grande do Sul 


$\begin{array}{ll}\text { RA } & \text { Região Administrativa do Distrito Federal } \\ \text { Senalif } & \text { Seminário Nacional das Licenciaturas dos Institutos Federais } \\ \text { SK } & \text { Stakeholder } \\ \text { SM } & \text { Salário mínimo } \\ \text { SUP } & \text { Supervisor do Pibid } \\ \text { UECE } & \text { Universidade Estadual do Ceará } \\ \text { UEL } & \text { Universidade Estadual de Londrina } \\ \text { UFC } & \text { Universidade Federal do Ceará } \\ \text { UNB } & \text { Universidade de Brasília } \\ \text { UNIFAL } & \text { Universidade Federal de Alfenas } \\ \text { UNIRIO } & \text { Universidade Federal do Estado do Rio de Janeiro } \\ \text { UTFPR } & \text { Universidade Tecnológica Federal do Paraná }\end{array}$




\section{SUMÁRIO}

INTRODUÇÃO

1 SOBRE FORMAÇÃO DE PROFESSORES NO BRASIL - QUESTÕES HISTÓRICAS, FORMAÇÃO INICIAL EM LICENCIATURA, ESTÁGIO, ASPECTOS POLÍTICOS ……...............................................15

1.1 QUESTÕES HISTÓRICAS SOBRE A FORMAÇÃO DE PROFESSORES................................................15

1.2 FORMAÇÃO INICIAL DOCENTE EM CURSOS DE LICENCIATURA ....................................................17

1.3 O ESTÁGIO SUPERVISIONADO NA ATUALIDADE BRASILEIRA: ENCONTRO ENTRE TEORIA E PRÁTICA? ......22

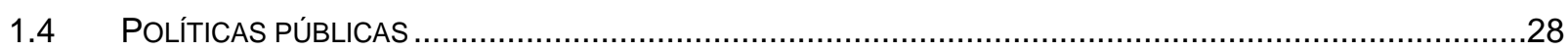

2 DA PESQUISA: OBJETO, PROBLEMA, JUSTIFICATIVA, OBJETIVOS METODOLOGIA...............31

2.1 O PROBLEMA: ESCASSEZ DE PROFESSORES COM FORMAÇÃO ADEQUADA PARA ATUAR NA EDUCAÇÃO

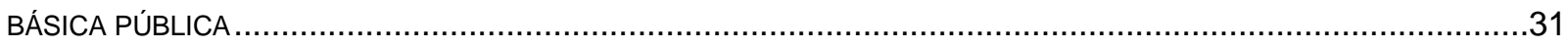

2.2 COMO FUNCIONA O PROGRAMA INSTITUCIONAL DE BOLSA DE INICIAÇÃO À DOCÊNCIA ......................36

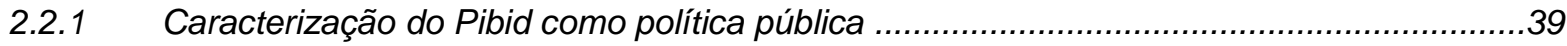

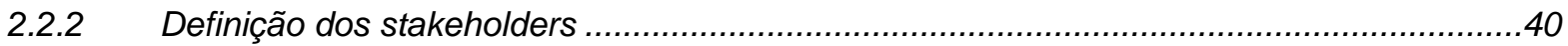

2.2.3 Instituições implementadoras do Pibid .......................................................................41

2.2.4 Público-alvo: a quem se destina o Pibid? .....................................................................41

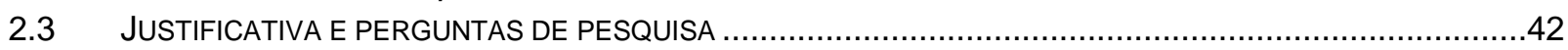

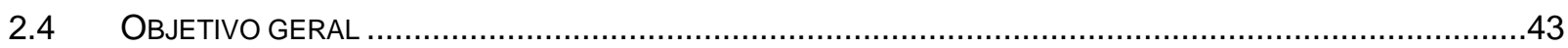

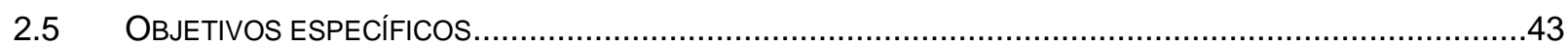

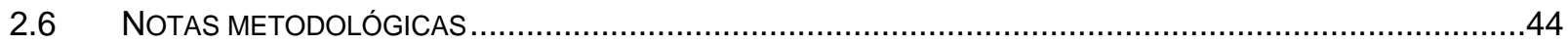

3 ESTADO DO CONHECIMENTO - O QUE JÁ FOI PESQUISADO SOBRE O PIBID ......................48

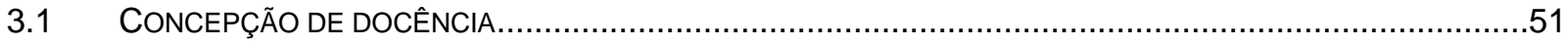

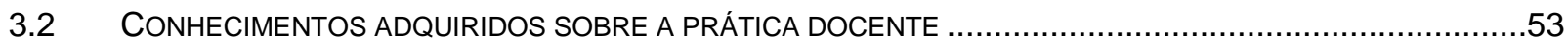

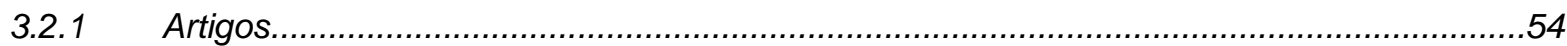

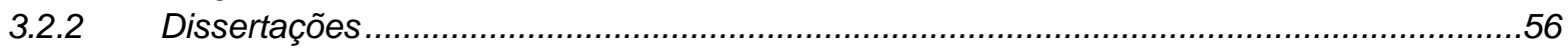

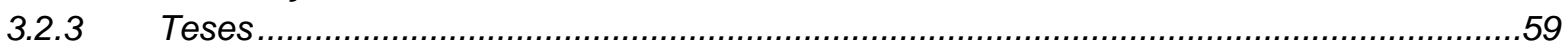

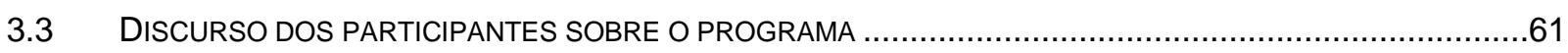

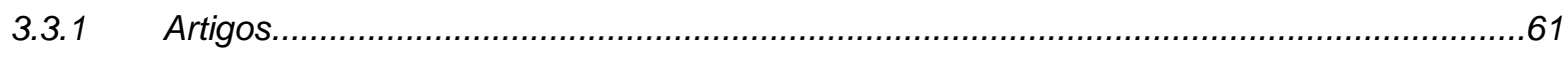

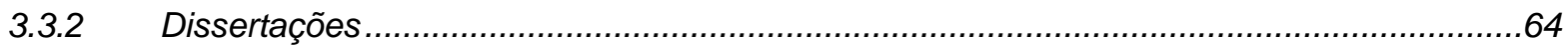

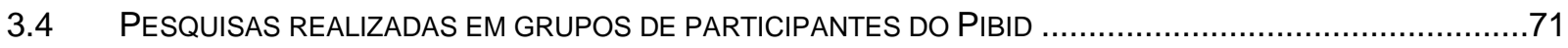

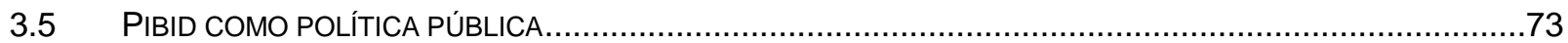

4 SUBPROJETO PIBID FÍSICA NA UNB: CONSTRUÇÃO E DESENVOLVIMENTO DE UM MODO

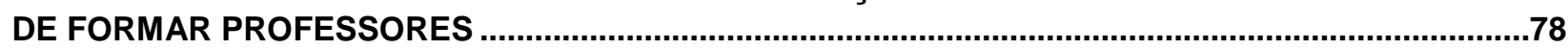

4.1 O SUBPROJETO PIBID FísICA DA UNIVERSIDADE DE BRASÍLIA ........................................................79

4.1.1 Contextos educacional da região onde o projeto será desenvolvido..................................80

4.1.2 Escolas da rede pública de ensino onde se pretende inserir os alunos ............................84

4.1.3 Ações/estratégias para inserção dos bolsistas nas escolas .............................................85

4.1.4 O subprojeto Pibid Física UnB apresentado à seleção da Capes ....................................91

4.1.5 Notas analíticas sobre a proposta do subprojeto Pibid Física UnB .................................93

4.2 A PROPOSTA IMPLEMENTADA: RELATÓRIO DE ATIVIDADES DO SUBPROJETO PIBID FíSICA UNB RELATIVO

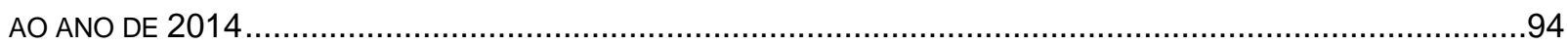

4.2.1 Dados da equipe participante e das escolas parceiras................................................96

4.2.2 Atividades desenvolvidas e resultados alcançados ......................................................98

4.2.3 Produções, impactos dificuldades e considerações finais ............................................101 
4.2.4 Notas analíticas sobre o relatório de atividades do subprojeto Pibid Física UnB relativo ao

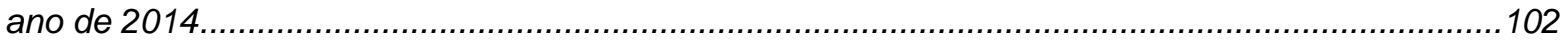

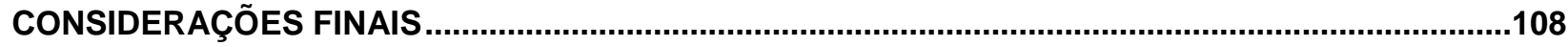

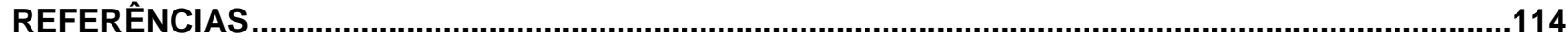




\section{INTRODUÇÃO}

O compromisso social de um cidadão pode se traduzir em sua participação na tomada de decisões sobre aspectos relevantes da vida coletiva. Nesse sentido, a atividade de pesquisa deve ser encarada como a assunção de um compromisso com toda a sociedade, e não somente uma repetição de procedimentos com vistas à obtenção do um título. Trata-se de fazer perguntas por vezes incômodas e prover respostas que contribuam com o permanente desenvolvimento do conhecimento. No caso da pesquisa social, ou em Ciências Humanas, é necessário visar antes de tudo a compreensão das relações entre os seres humanos. O rebatimento das descobertas de uma investigação precisa transbordar o campo de estudo e mirar a própria sociedade, sua constituição, seu funcionamento.

De 2010 a 2014, fizemos parte da equipe técnica gestora do Programa Institucional de Bolsa de Iniciação à Docência (Pibid) na Coordenação de Aperfeiçoamento de Pessoal de Nível Superior (Capes). Durante esse período,

desempenhamos diversas tarefas relacionadas ao planejamento e à execução do programa: escrita de editais; análise de planos de trabalho; pagamento de verbas de custeio e de capital; comunicação social do programa por meio de sua página de internet; trocas de coordenadores institucionais; organização de encontros de coordenadores; e elaboração de manuais que elucidam os procedimentos de gestão. Acompanhamos o crescimento do programa desde quando ele contava com três mil participantes. Atualmente, em 2014, são ofertadas mais de 90 mil cotas de bolsas. Sua proposta de integração entre universidade e escola chegou a ser incluída na Lei de Diretrizes e Bases da Educação Nacional (BRASIL, 1996, art. 62, § 5o). Essa proposta e sua aplicação cotidiana são o objeto deste estudo.

$\mathrm{Na}$ atuação como integrante da equipe técnica gestora do Pibid, sentíamos o incômodo de não conhecer os projetos implementados. Isso porque não era parte da rotina de trabalho o acompanhamento dos projetos nem a análise das prestações de contas. Ou seja, todo o esforço institucional estava concentrado na viabilização dos 
repasses de recursos, com vistas a executar o orçamento de modo a não devolver nenhuma parte do crédito à União.

A equipe que assumira o programa era formada por jovens recém-ingressos na Capes, muitos sem qualquer experiência em gestão pública e que não receberam treinamento para desempenhar sua função. Naturalmente, o resultado era a proliferação de problemas administrativos, por vezes graves.

Conforme a equipe ganhava experiência, o programa se tornava mais organizado, e o objetivo de acompanhar a execução dos projetos e analisar as prestações de contas parecia próximo. Contudo, certamente porque o programa se apresentava um pouco mais estruturado, ordens superiores demandavam a abertura de novas chamadas de projetos, com vistas a expandir o número de participantes. Uma vez mais a equipe se encontrava na situação desagradável de compor quebracabeças administrativos para atender a desejos políticos cuja motivação não parecia se pautar por finalidades educacionais.

Tantas reviravoltas administrativas tornavam o trabalho no Pibid um sem-fim de procedimentos, alheio à realidade em volta; a constante reestruturação do programa absorvia todo o tempo útil, de modo que o conhecimento in loco das atividades desenvolvidas pelos bolsistas era preterido. Percebemos que nossa contribuição com o Pibid seria mais efetiva se nos distanciássemos do cotidiano operacional para observar a outra extremidade, as atividades dos projetos. O Pibid se mostrava um objeto de estudos, cujo conhecimento deveria ser disponibilizado à sociedade.

A investigação proposta aqui busca compreender uma política de incentivo à qualificação da formação inicial de professores, a partir dos resultados apresentados pelos próprios agentes da "ponta": professores universitários, docentes de escolas e alunos de licenciatura. Eis a perspectiva que adotamos para contribuir com a educação brasileira, com o Pibid e com a Capes. Tal preocupação nos aproximou da Faculdade de Educação da Universidade de Brasília e do Grupo de Estudo e Pesquisa sobre Formação e Atuação de Professores/Pedagogos (GEPFAPe), no âmbito dos quais desenvolvemos este trabalho.

Esta dissertação é composta por seis seções. O capítulo 1 traz aspectos históricos da relação entre teoria e prática na formação de professores no Brasil e 
uma discussão sobre as diretrizes curriculares nacionais. Em seguida, no capítulo II, apresentamos objeto, problema e justificativa da pesquisa, bem como seus objetivos. A terceira parte é uma revisão do estado do conhecimento sobre o Pibid. Notas metodológicas sobre a pesquisa compõem o quarto capítulo. O cerne deste trabalho está no capítulo 5 , no qual são analisados proposta e relatório de atividades do subprojeto Pibid Física UnB. Nas considerações finais, pontuamos algumas questões relacionadas às discussões e expomos nosso posicionamento sobre a análise realizada. 


\section{SOBRE FORMAÇÃO DE PROFESSORES NO BRASIL - QUESTÕES HISTÓRICAS, FORMAÇÃO INICIAL EM LICENCIATURA, ESTÁGIO, ASPECTOS POLÍTICOS}

Neste capítulo, apresentamos reflexões de autores sobre a formação de professores no Brasil. As quatro subseções abordam questões históricas da formação docente, formação docente em nível de licenciatura, estágio curricular supervisionado e políticas públicas de formação de professores.

\subsection{Questões históricas sobre a formação de professores}

A seguinte seção traz um apanhado histórico sobre a questão da prática na formação de professores no Brasil, a título de preparação para a compreensão do contexto atual das definições regulatórias, apresentado nas seções 1.2 e 1.3. Essa mirada nos permite perceber o quanto a formação prática profissional para atuação na educação básica carece de atenção do estado, o que resulta em reflexos negativos para a qualidade da educação dos docentes.

A formação de docentes para o nível básico de instrução desenvolveu-se no Ocidente apenas no século XIX, após a Revolução Francesa de 1789 pôr em pauta a educação popular na Europa. Não desconsideramos a clássica experiência do sacerdote Jean-Baptiste de La Salle e seu Séminaire des Maîtres de l'Ecole, de 1685, voltado à instrução do povo, com viés eclesiástico. Ainda no final do século XVIII, a França napoleônica inaugura a Ecole Normal, instituição destinada especificamente à formação de docentes para atuação nas escolas, modelo que se disseminou pelo continente, sendo mimetizado também nos Estados Unidos da América (SAVIANI, 2009).

No Brasil, a independência em relação a Portugal, ocorrida em 1822, iniciou a discussão sobre a necessidade de preparar os docentes, com a intenção de organizar a educação do povo. Disseminar a instrução para as camadas populares, com o objetivo de formar contingente de trabalhadores visando ao desenvolvimento econômico, era uma grande questão entre os países ocidentais no século XIX 
(GAUTHIER, 2010, p. 186). O Brasil demonstrava seguir essa tendência, com um governo influenciado pelos ideais filosóficos do Positivismo. Saviani (2009) enumera seis etapas históricas da formação de professores no Brasil transcorridas após a independência:

1. Ensaios intermitentes de formação de professores (1827-1890). Inicia-se com a Lei das Escolas de Primeiras Letras, que obrigava os professores a se formarem no método do ensino mútuo, com recursos próprios; chega a 1890, com as Escolas Normais. Os currículos das Normais eram os mesmos das escolas de primeiras letras, sem atenção ao preparo didático-pedagógico. Couto Ferraz, presidente da província do Rio de Janeiro, crítico do modelo normalista, chegou a fechar a primeira escola, sediada em Niterói. Em vez de frequentar escolas, os pretendentes ao cargo tornavam-se professores adjuntos, acompanhando regentes de classe para adquirir prática. Essa iniciativa não vingou, e novas Escolas Normais foram abertas.

2. Disseminação das Escolas Normais (1890-1932). Iniciada com a reforma paulista, quando se enfatizou a prática docente por meio da criação de uma escolamodelo anexa ao centro formador.

3. Organização dos Institutos de Educação (1932-1939). Encabeçados pelas reformas de Anísio Teixeira no Distrito Federal (1932) e de Fernando de Azevedo, em São Paulo (1933), os centros de formação estimulavam a pesquisa para além do ensino. As Escolas Normais foram transformadas em Escolas de Professores. $O$ extenso currículo previa matérias como biologia, sociologia e história, além de muitas disciplinas ligadas a práticas e técnicas, desde o primeiro ano.

4. Organização e implantação dos Cursos de Pedagogia e de Licenciatura e estabelecimento do modelo das Escolas Normais (1939-1971). Os Institutos de Educação foram incorporados a universidades, e o modelo " $3+1$ " de formação para licenciaturas e Pedagogia foi universalizado. Nesse esquema, o aluno perfaz três anos de conteúdos disciplinares e um ano de prática. Entraram em desuso as escolas experimentais. Esse movimento parece ter contribuído com a situação dualista na formação de professores, na medida em que os conteúdos ditos cognitivos marcaram a formação, em detrimento dos aspectos didático e pedagógico. 
5. Substituição da Escola Normal pela Habilitação Específica de Magistério (1971-1996). Com a reforma da educação básica e a mudança de nomenclaturas, a formação para atuação até a $6^{\underline{a}}$ série do $1^{\circ}$ grau passou a integrar o ensino médio como Habilitação Específica para o Magistério. Daí em diante, e para a docência no 2o grau, tornou-se necessário possuir formação em nível superior.

6. Institutos Superiores de Educação, Escolas Normais Superiores e o novo perfil do Curso de Pedagogia (1996-2006). A nova regulamentação federal assegurou às duas instituições citadas a possibilidade de formar docentes como alternativa aos cursos universitários de licenciatura. Saviani (2009, p. 148) considera que esse último movimento se trata da insistência do Estado brasileiro em promover uma formação "aligeirada" e de baixa qualidade (p. 148).

Nossa incursão pela história brasileira permite perceber uma dificuldade em estabelecer o componente prático na formação de professores. Salvo experiências esparsas e descontinuadas, o currículo da formação em nível universitário costuma enfatizar o que Saviani (2009, p. 147) chama de modelo dos conteúdos culturaiscognitivos, que privilegiam a transmissão de cultura geral e de matérias da área de conhecimento disciplinar do que se vai ensinar. Nas Escolas Normais, costuma prevalecer o modelo pedagógico-didático, para o qual o preparo do professor não se consolida sem prática de ensino. Esses dois modelos coexistem no Brasil de forma dicotômica, antagonista (ibidem, p. 150). Na seção 1.3, conferimos como o componente prático da formação se encontra definido atualmente nos cursos de licenciatura, após o estabelecimento, em 2002, das Diretrizes Curriculares Nacionais.

\subsection{Formação inicial docente em cursos de licenciatura}

Conforme vimos na seção 1.1, a formação inicial docente no Brasil apresenta distorções derivadas de sua história: regulação insuficiente; currículos que apresentam escassa definição sobre a relação entre teoria e prática e pouca ênfase no ensino de práticas e técnicas docentes. Discutiremos nesta seção a formação de professores nos cursos superiores de licenciatura, considerados pela legislação atual como o nível de escolarização exigido aos docentes da educação básica. 
Gatti (2010) considera quatro aspectos ao abordar a formação de professores no Brasil: legislação, características socioeducacionais dos licenciandos, características dos cursos formadores de professores, currículos e ementas. Quanto à legislação, Gatti observa a prevalência histórica da formação de bacharéis em detrimento da de professores para atuação em níveis de ensino fundamental e médio. Isso ocorre desde a década de 1930, quando as poucas universidades brasileiras introduziram o "modelo 3+1", a fim de acrescentar aos bacharéis um verniz didático. 0 modelo foi adotado também pelos cursos de Pedagogia, regulamentados no ano de 1939 (GATTI, 2010, p. 1356).

Esse ordenamento da formação, consagrado no início do século $X X$, persiste nas licenciaturas mesmo após o estabelecimento das Diretrizes Curriculares Nacionais em 2002, com poucos ajustes no sentido de integrar os saberes disciplinares da prática docente. No Brasil não se encontram centros de formação que ofertem base comum formativa - os centros formadores mantêm uma diferenciação disciplinar que gerou uma hierarquização crônica entre os "especialistas" em suas áreas e os "polivalentes", estes voltados aos primeiros níveis de ensino. Essa diferenciação se manifesta sobretudo nos salários, mas também nas representações sociais sobre cada profissional, a ponto de se tornar um entrave às tentativas de reestruturar as bases da formação docente com vistas a uma maior integração entre os conhecimentos (GATTI, 2010, p.1358).

Ao analisar os cursos de licenciatura, a autora lança mão de dados de sinopses estatísticas do Instituto de Estudos e Pesquisas Educacionais Anísio Teixeira (Inep). De 2001 a 2006, a oferta de vagas em Pedagogia subiu 94\%, enquanto o conjunto de todas as outras áreas teve acréscimo de $52 \%$. Contudo, o número de matrículas efetivadas nesse período não acompanhou o ritmo de expansão da oferta, crescendo apenas 37\% e 40\%, respectivamente.

O maior número de alunos de licenciatura está matriculado em universidades (63\%) e em instituições privadas (64\% de alunos de Pedagogia, e $54 \%$, do conjunto das demais licenciaturas). Segundo dados de 2006, o nível de conclusão de curso em licenciaturas estava situado na taxa média de $24 \%$. 
Entre os alunos, a escolha pela docência assume um caráter de "seguro desemprego", ou de saída para uma situação de vida de poucas alternativas. O alunado está predominantemente na faixa etária dos 18 aos 24 anos, considerada ideal; em Pedagogia, contudo, apenas $35 \%$ dos alunos se encontram no período de vida correto para participar de um curso superior.

Três quartos dos licenciandos são mulheres, número que remonta às Escolas Normais, nas quais ocorreu a própria expansão da escolarização em nível médio das mulheres no Brasil. Metade dos estudantes tem renda familiar de três a dez salários mínimos, com alguma desvantagem para os alunos de Pedagogia, e 39\% dos alunos têm renda de até três salários mínimos.

No que diz respeito ao nível de formação, dentre os pais de licenciandos há $10 \%$ de analfabetos; quase metade tem até o $4^{\circ}$ ano do ensino básico, mas $29 \%$ dos pais têm ensino médio. $O$ curso de Pedagogia apresenta a proporção de pais de alunos com escolaridade mais baixa entre as licenciaturas. Dois terços dos alunos de licenciatura estudaram em escolas públicas e o desempenho dos ingressantes no Enem em 2008 não passou dos 37 pontos de 100 possíveis. Durante sua formação, $63 \%$ dos alunos usam apostilas ou cópias de trechos de livros. Metade dos alunos de Pedagogia completa sua formação sem avaliações individuais.

Ao voltar seu olhar para os currículos, Gatti (2010) elenca quatro cursos para análise - Ciências Biológicas, Língua Portuguesa, Matemática e Pedagogia. Em todos os currículos estudados, foram encontradas as seguintes características: currículo fragmentado em conjuntos disciplinares dispersos; predominância de abordagens descritivas e de pouca integração entre disciplina e prática nas disciplinas de formação específica, além de prioridade na discussão sobre o porquê do ensino, com apresentação vaga e figurativa das técnicas; carga horária reduzida das disciplinas de formação específica para a docência em relação aos conteúdos disciplinares; vagas descrições das atividades de estágio; a prática docente muitas vezes dispersa em várias disciplinas ou em separado, sem ementas claras; falta de articulação entre disciplinas de formação pedagógica e de conteúdos específicos; redundâncias de conteúdos entre disciplinas. 
Para Gatti (2010), essa fragmentação disciplinar e a pouca atenção às técnicas de ensino estão no cerne dos problemas relativos aos cursos de formação de professores. Em sua conclusão, a autora defende que a formação de docentes não pode ser adendo da formação de cientistas, mas deve cumprir a função própria da escolarização na sociedade - transmitir o conhecimento acumulado e consolidar práticas e valores da vida civil do país.

Formar professores para a educação básica deve partir da prática; mas essa ideia encontra resistência na tradição disciplinar predominante nas instituições formadoras de docentes e também nas formadoras de cientistas. Em 2008, mais um tipo de instituição recebeu a designação de formar professores para a educação básica: os Institutos Federais de Educação, Ciência e Tecnologia (IF).

Criados a partir da reorganização do ensino técnico federal pela Lei $n$. $11.892 / 2008$, os IF são a continuidade de iniciativas governamentais de fomento à oferta de mão-de-obra especializada para os setores produtivos do país, iniciadas em 1909, com a instituição das Escolas de Aprendizes e Artífices (BRASIL, 1909). Sua diferença em relação às universidades é a possibilidade de oferta técnica e profissional, além do ensino médio. Os IF ofertam também educação superior incluindo licenciaturas, e mesmo cursos de pós-graduação stricto sensu (BRASIL, 2008b, art. $7^{\circ}$ ).

Atualmente 562 instituições compõem a Rede Federal de Educação Profissional e Tecnológica, das quais apenas 38 são IF. Os demais componentes são Centros Federais de Educação Tecnológica (Cefet), Escolas Técnicas Vinculadas às Universidades Federais e a Universidade Tecnológica Federal do Paraná (UTFPR). Cada uma das instituições possui atribuições distintas, mas muitas finalidades e objetivos se sobrepõem.

Alguns pressupostos orientam os cursos dos IF, como atuação em ensino, pesquisa e extensão; pesquisa baseada em princípios científicos; defesa do uso do conhecimento nas diferentes dimensões da vida humana, integrando ciência, tecnologia, cultura e conhecimentos específicos; e diálogo entre os diferentes cursos da educação profissional e tecnológica (BRASIL, 2008b). Esses também são objetivos 
das universidades e dos Cefet, o que evidencia a sobreposição de atribuições supracitada.

Diante da necessidade legal de os IF destinarem o mínimo de $20 \%$ de suas vagas para cursos de licenciatura (BRASIL, 2008b), Lima e Silva (2011) questionam os pressupostos desses novos cursos: existem atributos que os diferenciam dos cursos ofertados por outras IES? Essa iniciativa de formar professores em escolas de natureza híbrida pretende apenas atender a demandas quantitativas do governo por mais docentes? As autoras usam como corpus do estudo leis e propostas do governo e trabalhos apresentados nos eventos "Seminário Nacional das Licenciaturas dos Institutos Federais" (Senalif) e "Fórum Nacional das Licenciaturas dos Institutos Federais" (Fonalifes).

Para as autoras, na década de 2000, a formação nas escolas técnicas se pautava pelo aligeiramento do ensino, com vistas a formar mais pessoas usando menos recursos - humanos, financeiros, bibliográficos e de infraestrutura. Nesse sentido, acrescentamos que a ideia não se diferenciaria da concepção da educação do século XIX: derivada de demandas econômicas, voltada para a economia (GAUTHIER, 2010, p. 179-180).

Ainda na década 2000, conforme as autoras, houve melhorias estruturais e nos resultados em avaliações de cursos, mas as licenciaturas da rede federal técnica permaneciam sem identidade. Para pensá-la, foram realizados em 2010 os eventos Senalif e Fonalifes, cujos documentos reforçam a intenção de tornar os institutos federais centros de excelência - não apenas na formação de professores para os cursos técnicos, mas também para a educação básica.

Nas apresentações dos inventos notou-se a inclinação pelo desenvolvimento da pesquisa para a promoção da autonomia intelectual dos docentes. Para tanto, o cômputo das horas/aula também deve contabilizar o trabalho realizado fora da sala de aula; deve ser atendida a demanda pela aproximação entre teoria e prática, por abordagens multiculturais e pela inclusão da disciplina de Libras no currículo?; o uso de Tecnologias de Informação e Comunicação (TIC) precisa ser expandido; deve haver entendimento da centralidade do trabalho como princípio educativo; e é 
necessária a superação do modelo " $3+1$ ", que distancia licenciaturas de bacharelados.

As autoras concluem alertando para a possibilidade de os IF, em suas licenciaturas, se tornarem formadores meramente quantitativos, orientados apenas pela demanda crônica de professores do país, descuidando da qualidade da formação, a exemplo de outras iniciativas anteriores. Essa ideia de qualidade, porém, não pode ser sinônimo de "qualidade total", conceito de programa homônimo implantado no país nos anos 1980, que desloca a questão para finalidades competitivas e lucrativas. O potencial dos IF reside na possibilidade da reflexão coletiva para delinear os caminhos, evitando a mera aplicação de normativas governamentais.

Os abrangentes estudos destacados indicam que a formação inicial ainda se encontra fragilizada do ponto de vista regulatório e executivo pelo Estado brasileiro, com notórias consequências negativas para a solidez da formação. Não existe uma definição sobre o melhor formato para os cursos de formação docente, os currículos propostos deixam de lado o componente prático e novas instituições criadas para a educação técnica recebem por enxerto a atribuição de formar professores. É nesse contexto fragilizado que se criam novas iniciativas de "valorização" da profissão e formação docentes, conforme desenvolveremos no capítulo 2 .

\subsection{O estágio supervisionado na atualidade brasileira: encontro entre teoria e prática?}

O objetivo da formação de professores é conseguir que o docente realize a fusão de conteúdos disciplinares e das técnicas de ensino durante sua atuação. Nossa assertiva corrobora a afirmação de Ponte (1998, p. 4), feita no âmbito de uma discussão sobre o desenvolvimento profissional de docentes em Matemática:

[...] a preparação profissional não se reduz a um somatório de conhecimentos de diversos domínios. Na sua prática educativa, o professor ter de ser capaz de agir e, muitas vezes, de agir em situações de grande pressão. Podemos dizer que a chave da competência profissional é a capacidade de equacionar e resolver - em tempo oportuno - problemas da prática profissional. Isso exige não só competências teóricas e competências práticas mas também competências na relação teoria-prática. (grifo do autor). 
Nas seções 1.1 e 1.2, discorremos sobre como a formação de professores praticada no Brasil pode ser compreendida como um somatório de conteúdos disciplinares a um módulo de técnicas de ensino - situação geradora de um dualismo entre o privilégio concedido a um ou a outro nos cursos. Essa é uma análise encontrada com frequência na literatura (GATTI, 2010; SAVIANI, 2009; TANURI, 2000). Veremos aqui como está disposta essa questão no ordenamento jurídico do Estado brasileiro, o qual prevê que o aprendizado da prática profissional docente se concentra em disciplinas curriculares de estágio.

Em 2002, os cursos de licenciatura brasileiros tiveram sua primeira definição de diretrizes a serem seguidas para organização institucional e curricular. Essa tentativa de padronização está consolidada na Resolução CNE/CP n. 1/2002. Durante todo o texto, a prática é citada como necessária e deve ser proporcionada ao longo do curso inteiro: entre os princípios a serem observados pelos cursos está a "coerência entre a formação oferecida e a prática esperada do futuro professor" (CNE, 2002, art. $3^{\circ}$, II). Mais à frente, no art. $6^{\circ}, \mathrm{IV}, \S 3^{\circ}, \mathrm{VI}$, diz-se necessário um "conhecimento advindo da experiência", ao se definir os conhecimentos exigidos para a constituição de competências.

Os projetos pedagógicos devem ser próprios, formulados por direções e colegiados das instituições. Estas podem criar Institutos Superiores de Educação para oferecer cursos normais superiores, caso não possuam autonomia universitária - aqui notamos a continuidade possível dos tradicionais centros de ensino mencionados anteriormente. A organização da matriz curricular deve se expressar em "eixos articuladores", dentre os quais está o eixo das "dimensões teóricas e práticas".

Entretanto, consta dos art. 12 e 13 a mais extensa lista de menções, com seis tópicos tratando do tema prática/estágio, das quais destacamos os seguintes:

Art. 12. Os cursos de formação de professores em nível superior terão a sua duração definida pelo Conselho Pleno, em parecer e resolução específica sobre sua carga horária.

$\S 1^{\circ}$ A prática, na matriz curricular, não poderá ficar reduzida a um espaço isolado, que a restrinja ao estágio, desarticulado do restante do curso.

$\S 2^{\circ}$ A prática deverá estar presente desde o início do curso e permear toda a formação do professor.

$\S 3^{\circ}$ No interior das áreas ou das disciplinas que constituírem os componentes curriculares de formação, e não apenas nas disciplinas pedagógicas, todas terão a sua dimensão prática. 
Art. 13. Em tempo e espaço curricular específico, a coordenação da dimensão prática transcenderá o estágio e terá como finalidade promover a articulação das diferentes práticas, numa perspectiva interdisciplinar.

$\S 11^{\circ}$ A prática será desenvolvida com ênfase nos procedimentos de observação e reflexão, visando à atuação em situações contextualizadas, com o registro dessas observações realizadas e a resolução de situaçõesproblema.

$\S 2^{\circ}$ A presença da prática profissional na formação do professor, que não prescinde da observação e ação direta, poderá ser enriquecida com tecnologias da informação, incluídos o computador e o vídeo, narrativas orais e escritas de professores, produções de alunos, situações simuladoras e estudo de casos.

$\S 3^{\circ}$ O estágio curricular supervisionado, definido por lei, a ser realizado em escola de educação básica, e respeitado o regime de colaboração entre os sistemas de ensino, deve ser desenvolvido a partir do início da segunda metade do curso e ser avaliado conjuntamente pela escola formadora e a escola campo de estágio. (CNE, 2002).

Aqui estão presentes todas as diretrizes sobre a prática na formação docente. Primeiro, sua carga horária, definida apenas anos depois por meio da Resolução CNE/CP n. 2/2009: das 2.800 horas mínimas para integralização dos cursos, 400 devem contemplar prática como componente curricular, e a mesma quantidade deve ser destinada ao estágio curricular - iniciado a partir da segunda metade do curso. Cabe mencionar que $o$ texto também exorta os cursos a ofertarem atividades suplementares de prática docente, pois o estágio supervisionado, podemos assim entender, não esgota as possibilidades formativas práticas.

Nas diretrizes específicas do curso de Física, disciplina focada por esta investigação, dispostas no Parecer CNE/CES 1.304/2001, a estrutura dos cursos é proposta em uma estrutura modular: um núcleo comum, que ocupa $50 \%$ da carga horária do curso, e módulos sequenciais, que definem as ênfases da formação. Existem quatro possibilidades de ênfase profissional a ser escolhidas pelos estudantes (Figura 1): 
Figura 1 - Perfis dos formandos em Física no Brasil, segundo as Diretrizes Curriculares Nacionais
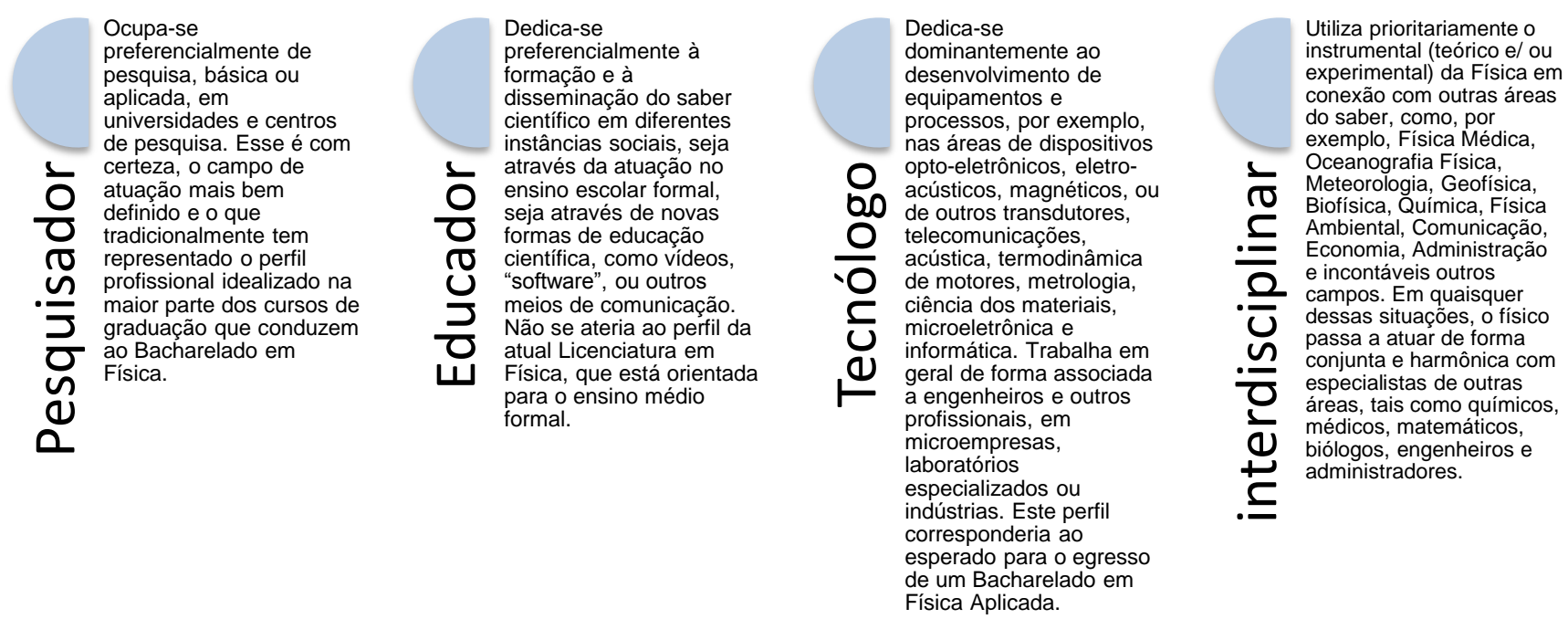

Fonte: CNE, 2002. Elaboração do autor.

Ao discorrer sobre o estágio, o texto das diretrizes curriculares de Física é lacônico:

"Os estágios realizados em instituições de pesquisa, universidades, indústrias,
empresas ou escolas devem ser estimulados na confecção dos currículos plenos
pelas IES.
"Todas as modalidades de graduação em Física devem buscar incluir em seu
currículo pleno uma monografia de fim de curso, associada ou não a estes estágios.
Esta monografia deve apresentar a aplicação de procedimentos científicos na
análise de um problema específico" (CNE, 2001)

A estrutura "modular" do curso de Física, proposta pelas diretrizes, assemelhase ao "modelo 3+1" discutido nas seções 1.1 e 1.2, no qual conteúdos disciplinares e prática docente estão compartimentalizados no âmbito da formação docente.

Pimenta e Lima (2010) discutem a formação de professores e pedagogos a partir da relação entre teoria e prática nas atividades de estágio. Para as autoras, a atividade de estágio deve superar a tradicional redução à atividade prática instrumental e poderá consistir em atividade de pesquisa. Os currículos das licenciaturas se assemelham a aglomerados de disciplinas isoladas, desconexas também da realidade social que lhes fornece subsídio de conhecimento. Neles, não se pode identificar o significado de ser professor; o tipo de profissional que se quer 
formar; qual a contribuição da área específica para a sociedade; e a ligação com a ponta do conhecimento diariamente atualizado.

Cursos de formação de professores dedicam parcelas muito inferiores de carga horária a disciplinas práticas, notadamente em cursos realizados mediante convênios entre secretarias de educação e universidades, nos quais se observam figuras como o "estágio a distância", cujas cargas horárias são comprovadas por meios burocráticos sem o devido acompanhamento.

Em busca da superação da dicotomia entre prática e teoria, as autoras discutem as formas como a prática está apropriada no cotidiano da formação docente. A prática é compreendida como "imitação", aprendizado por repetição de uma tarefa, à qual se acrescentam adaptações oriundas de experiência. Aqui, o estágio se reduz à observação de um professor em sala e à tentativa de espelhamento. Em outra perspectiva, a prática é vista como uma técnica, um conjunto de procedimentos para desenvolver ações e obter resultados, a exemplo da medicina.

Um estágio "técnico" se atém às horas das práticas, nas quais são desenvolvidas habilidades relativas ao manejo de classe ou preenchimento de diagramas de observação. Nesses estágios, é comum encontrar oficinas de confecção de material didático e atividades de microensino, com vistas ao treinamento para situações cotidianas. Para Pimenta e Lima (2010), essa perspectiva distancia o estágio da realidade escolar, pois não contempla a integração dos conteúdos disciplinares, além de reforçar o mito segundo o qual a mera aplicação de procedimentos promoverá a melhoria do aprendizado.

Ao ser levantada a crítica acima, as primeiras reações dos docentes foram no sentido de "negar" a didática e criticar as escolas em geral - pois reprodutoras de ideologias -, o que gerou um movimento de estágios cujo objetivo era apontar as falhas dos agentes envolvidos na educação, sem apontar possibilidades. Essa postura acentuou o distanciamento entre escola e universidade ao ponto de haver recusas de escolas em receber estagiários - até que as secretarias intercedessem no conflito, obrigando suas escolas a receber os licenciandos praticantes.

Para compreender o papel da teoria da prática docente, Pimenta e Lima (2010) introduzem o conceito de ação docente. Aqui, "prática" é entendida como movimento 
institucionalizado de educar de forma organizada; e "ação" se refere ao modo como as pessoas se relacionam com o mundo e como os professores lidam com seus alunos. A ação está, portanto, inscrita na prática, da mesma forma que pessoas compõem instituições e tradições. No cotidiano de suas ações docentes, os professores muitas vezes perdem de vista os objetivos que os orientam e os contextos sociais em que se inserem. O papel da teoria é o de "iluminar" questões e fornecer elementos de investigação que contribuam para o questionamento das práticas institucionais e das ações dos sujeitos.

As autoras reforçam o papel da teoria no estágio, chegando a afirmar que o estágio, "ao contrário do que se propugnava, não é atividade prática, mas atividade teórica, instrumentalizadora da práxis docente, entendida esta como a atividade de transformação da realidade" (PIMENTA; LIMA, 2010, p. 14). Por conseguinte, o estágio pode se transformar em atividade de pesquisa, na medida em que torna possível a análise dos contextos em que ele é realizado.

Conforme o modelo apresentado acima, o estudante assume uma postura investigativa em relação a seu cotidiano e renova seu conhecimento prático a partir da análise do contexto. Pimenta e Lima (2010) apontam o risco de essa perspectiva possibilitar a responsabilização do professor por todos os problemas do aprendizado dos alunos. Uma vez que o docente aprimora diariamente seus métodos, é esperado que seus alunos atinjam melhores resultados. Contudo, as condições das escolas e do regime de trabalho dos professores no Brasil impõem dificuldades ao desenvolvimento de uma pesquisa docente aprofundada.

As autoras concluem apontando caminhos para a superação do atual modelo de estágio: integrá-lo a todas as disciplinas, de modo a torná-lo presente desde 0 início do curso; desenvolvê-lo como trabalho coletivo, uma vez que o ensino não é uma tarefa individual do professor; alternar momentos de aprendizado na universidade e no campo de trabalho.

A leitura dos documentos oficiais permite perceber como o componente prático da formação não se encontra claramente definido nas normativas nacionais. Os conteúdos disciplinares, por sua vez, contam com extenso detalhamento. Essa discrepância reitera a formação de professores que Saviani (2009, p. 147) conceitua 
como "modelo de conteúdos culturais-cognitivos", mencionada na seção 1.1, quando apresentamos uma síntese da história da formação de professores no Brasil.

Associamos esse saber-fazer fundado na transmissão de conhecimento ao que Gauthier (2010) considera uma "tradição pedagógica" fundada no século XVII, a qual perpassou os séculos XVIII e XIX (p. 177), tendo sido questionada no fim do século XIX com as concepções científicas - investigadoras e atualizadoras dos métodos ( $p$. 187).

Nossa legislação não parece propor uma busca por atualização dos meios de se aprender componentes práticos de docência, deixando a cargo dos formadores de professores a transmissão de suas habilidades adquiridas por meio da experiência. $\mathrm{Na}$ seção 4.2.4, veremos como essa tradição ainda impacta a formação de professores nos dias atuais, estando presente em projetos cuja natureza seria a busca pela inovação.

\subsection{Políticas públicas}

Ao refletir sobre a história da formação docente, percebemos o quanto as decisões políticas sobre o assunto apresentam determinações frágeis e inconclusivas. Nesta seção, discutiremos os aspectos regulatórios da questão.

Scheibe (2010) se propõe a contribuir com a discussão sobre a valorização da profissão docente e de sua formação. Após apresentar dados do Estudo Exploratório sobre o Professor Brasileiro (INEP, 2009), a autora atribui à ausência de um sistema nacional de educação uma das razões pelas quais a profissão docente se encontra deficitária, destacando os seguintes pontos: os três entes federativos possuem atribuições e autonomia; existem professores ligados a municípios, estados e União; docentes urbanos, rurais, selecionados mediante concurso, e ligados a entidades patronais.

Essa situação de multiplicidade de vínculos empregatícios está na origem das diferenciações de planos de carreira, salários, jornadas, entre outros aspectos. Outro fator concorrente é a tradição disciplinar das instituições formadoras de professores, que distancia o aluno da prática profissional na escola: seus cursos não contam com 
um perfil do profissional a ser atingido com a formação. A partir da aplicação de diversas avaliações nacionais e externas sobre os alunos, houve aumento da pressão por resultados dos docentes que refletissem melhorias nos índices. As iniciativas governamentais de incentivos à evolução profissional por meio de premiações financeiras pelo cumprimento de metas é algo que escapa da questão central, que perpassa salários e condições de trabalho.

Para Scheibe (2010), existe um conflito nos marcos legais no tocante às políticas de valorização docente. De um lado, a Constituição e a LDB demandam planos de carreira, piso salarial nacional para professores e obrigatoriedade de formação superior para todos os docentes; de outro, o mesmo texto constitucional estabelece que municípios também compõem a Federação e, em outro movimento, promove a descentralização de competências - a qual demanda organização dos entes para o sucesso das iniciativas relativas à educação.

Ocorre que essa sistemática de distribuição de competências não se encontra bem regulamentada, e algumas atribuições acabam dissolvidas entre os entes; outras estão pesadamente centralizadas, como é o caso da valorização da profissão, centralizada na União por meio da LDB e de dispositivos como o Fundo de Manutenção e Desenvolvimento do Ensino Fundamental e Valorização do Magistério (Fundef) - Lei n. 9.424/1996. O fundo foi redesenhado para Fundo de Manutenção e Desenvolvimento do Ensino Básico e Valorização do Magistério pela Lei $n$. 11.494/2007, a qual prevê repasses federais a todas as etapas da educação básica até 2020 .

Outro exemplo de centralização, este relativo à valorização da formação, é a Política Nacional de Formação de Profissionais do Magistério da Educação Básica (Decreto n. 6.755/2009), que atribui à Capes o fomento a programas de formação inicial e continuada, como Parfor e Pibid. Essa política demanda articulação entre os entes, os quais não demonstram estar suficientemente engajados. Para além de iniciativas de valorização ligadas à remuneração - como o piso salarial nacional Scheibe (2010) percebe que o foco das políticas de educação desde a década de 1990 recai sobre a formação. 
A partir dos documentos originados dos eventos Coneb e Conae, além de uma contribuição do Conselho Nacional da Educação (Portaria CNE/CP n. 10/2009), a autora elenca e discute prioridades para a formação dos professores a serem contempladas no novo Plano Nacional de Educação (PNE 2011-2020 ${ }^{1}$ ) (SCHEIBE, 2010):

a) indissociabilidade entre valorização da carreira, formação e condições de trabalho para o desenvolvimento da docência, pois não é possível evoluir na qualidade da educação apenas com incentivos à formação docentes são profissionais, e o bom exercício de suas atividades demanda escolas em condições e planos de carreira atrativos;

b) necessidade de uma formação voltada para o modelo pedagógicodidático dos professores, aproximando conteúdos disciplinares e práticos - superação da crença de que o domínio dos conteúdos basta para a formação;

c) oferta de formação inicial dos professores preferencialmente na modalidade presencial - em uma tentativa de evitar a dispersão de esforços em formações apressadas e com frouxa avaliação, cujo único intuito é expandir a oferta de vagas.

d) extinção do curso Normal de nível médio, com vistas a aprofundar a qualidade da formação com embasamento acadêmico; avaliação da formação - trabalho coletivo de acompanhamento de cursos com vistas a subsidiar melhorias no sistema educacional.

${ }^{1}$ O PNE foi aprovado apenas em 2014, com vigência até 2024. Vide o capítulo 2. 


\section{DA PESQUISA: OBJETO, PROBLEMA, JUSTIFICATIVA, OBJETIVOS METODOLOGIA}

O capítulo 1 discorreu brevemente sobre o contexto histórico da formação de professores no Brasil. Formar professores para a educação básica em quantidade suficiente e com a qualidade necessária parece ser um problema crônico no país. Por outro lado, a profissão docente não é valorizada até os dias atuais, tanto que os egressos dos cursos de formação parecem não se interessar pela profissão de professor, e o que contribui para aprofundar a deficiência da oferta de docentes em quantidade suficiente para atender à demanda.

Uma série de ações governamentais foi lançada a partir de 2007 com o intuito de fortalecer a formação docente e valorizar a profissão. Nesta seção, retomamos a questão da formação de professores no Brasil com uma abordagem mais orientada para essas iniciativas mais recentes, dentre as quais se encaixa o Pibid, tema deste trabalho.

Inicialmente definiremos o problema público cuja solução é o objetivo de longo prazo do Pibid: a falta de professores na educação básica pública com formação específica para sua área de atuação. Segue a descrição do programa como uma política pública: estrutura organizacional, participantes, caracterização, instituições implementadoras e público-alvo. De posse do conjunto de informações descrito sobre o programa, apresentamos a justificativa para a realização deste trabalho, a questão norteadora do trabalho e os objetivos geral e específicos. Ao final do capítulo, estará definido o alvo da investigação a ser desenvolvida no capítulo 5 .

\subsection{O problema: escassez de professores com formação adequada para atuar na educação básica pública}

O Pibid se insere em um conjunto de políticas voltadas a combater um problema público: a deficiência na oferta de docentes com formação adequada para atuar na educação básica. Definiremos a seguir essa questão, pois entendê-la é necessário para compreender a natureza do programa. 
Em 1996 foi promulgado o marco legal de uma série de reformas educacionais, a Lei n. 9394/1996, ou Lei de Diretrizes e Bases da Educação Nacional (LDB). Em seu art. 62, a LDB determina a formação em nível superior como requisito fundamental para o exercício da docência na educação básica. Para docentes da educação infantil e das quatro primeiras séries do ensino fundamental, admite-se a formação em Ensino Médio Normal. Reforçando o pacto federativo, a lei estabelece que União, estados e municípios devem promover formação inicial e continuada em regime colaborativo. A formação inicial será preferencialmente presencial, admitida a possibilidade do uso de tecnologias de educação a distância, e inclui ao menos 300 horas de prática de ensino (BRASIL, 1996). Regulamento posterior fixou a carga horária de estágio em 400 horas (CNE, 2002).

A mais ambiciosa meta da LDB está contida no texto do art. $87, \S 4^{\circ}$, que institui a "Década da Educação", ao fim da qual somente seriam admitidos professores habilitados em nível superior ou formados por treinamento em serviço (BRASIL, 1996). Finda a Década em 2007, o salto esperado não fora atingido - e o dispositivo seria revogado apenas em 2013.

Sem dúvida, a meta era difícil de ser atingida, considerada a baixa atratividade da carreira docente: ser professor no Brasil não costuma ser a escolha de boa parte daqueles que aspiram a carreiras de nível superior (LAPO; BUENO, 2003; LEME, 2012; MORICONI, 2008; RUIZ et al., 2007; TARTUCE et al., 2010). Essa rejeição está demonstrada pela pesquisa de Tartuce et al. (2010), por exemplo, a qual abrangeu 1501 estudantes de Ensino Médio de escolas públicas e particulares das cinco regiões geográficas do Brasil. Os resultados apontam que apenas 2\% (31 estudantes) declaram abertamente intenção de se tornarem professores. Ou seja, a profissão está longe de compor o imaginário da juventude que aspira a um bom posicionamento profissional. Para os alunos pesquisados, a baixa remuneração é um dos principais impeditivos da carreira.

A constatação do desinteresse pela carreira docente está presente nos dados de procura por cursos de licenciatura nas universidades federais brasileiras. $\mathrm{Na}$ primeira década dos anos 2000, os cursos de licenciatura tiveram uma procura 
reduzida, principalmente se cotejada com a crescente demanda por bacharelados (Figura 2). Licenciaturas também apresentam baixas taxas de conclusão (Figura 3).

Figura 2 - Número de ingressos em cursos de licenciatura e bacharelado e taxa de crescimento anual no número de ingressos no período de 2002-2007 (ano de implementação do Pibid)

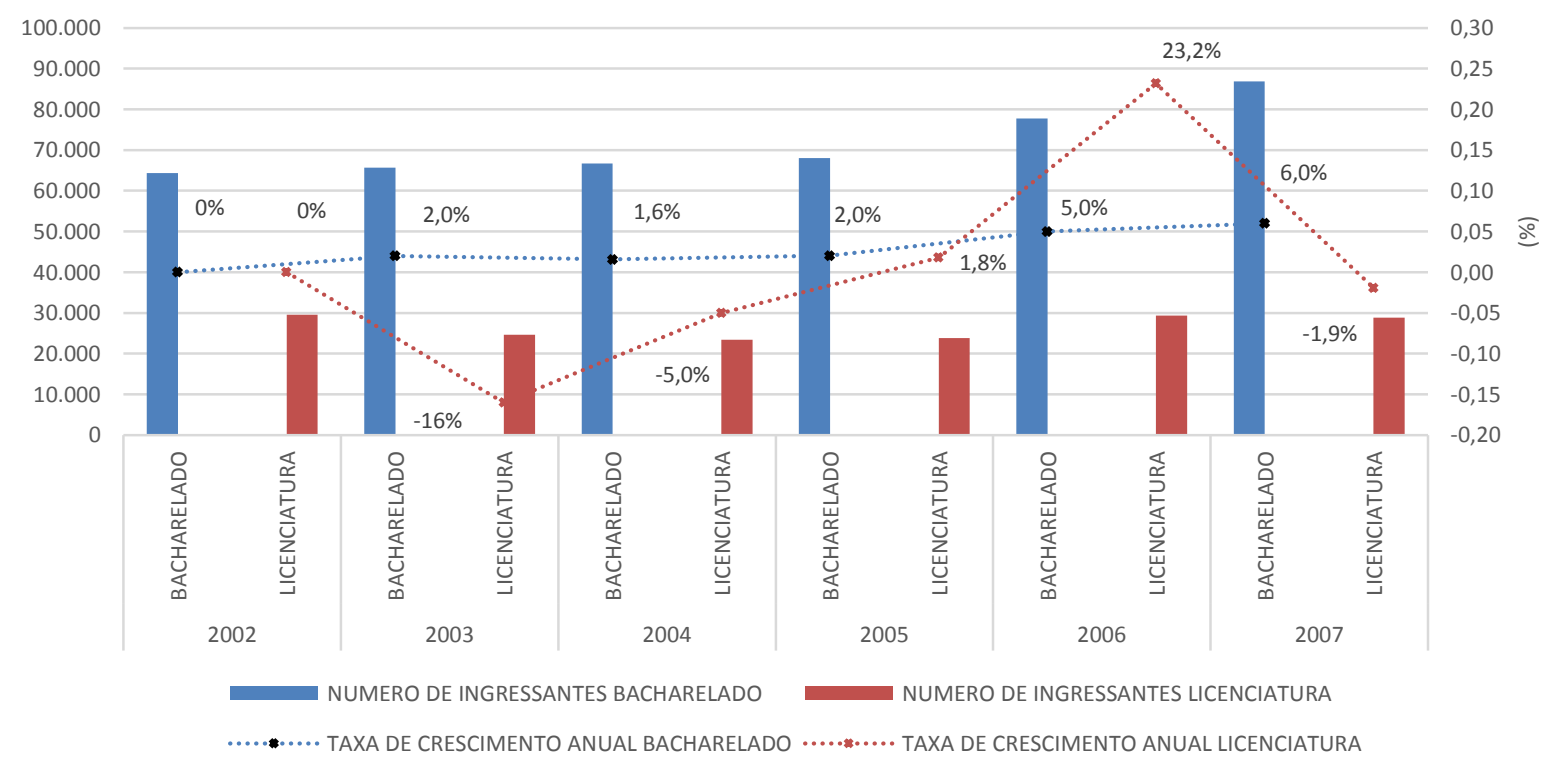

Fonte: Sinopse Estatística do Censo da Educação Superior de 2012 (INEP, 2012). Elaboração do autor.

Figura 3 - Número de concluintes em cursos de licenciatura e bacharelado e taxa de crescimento anual no número de concluintes no período de 2002-2007 (ano de implementação do Pibid)

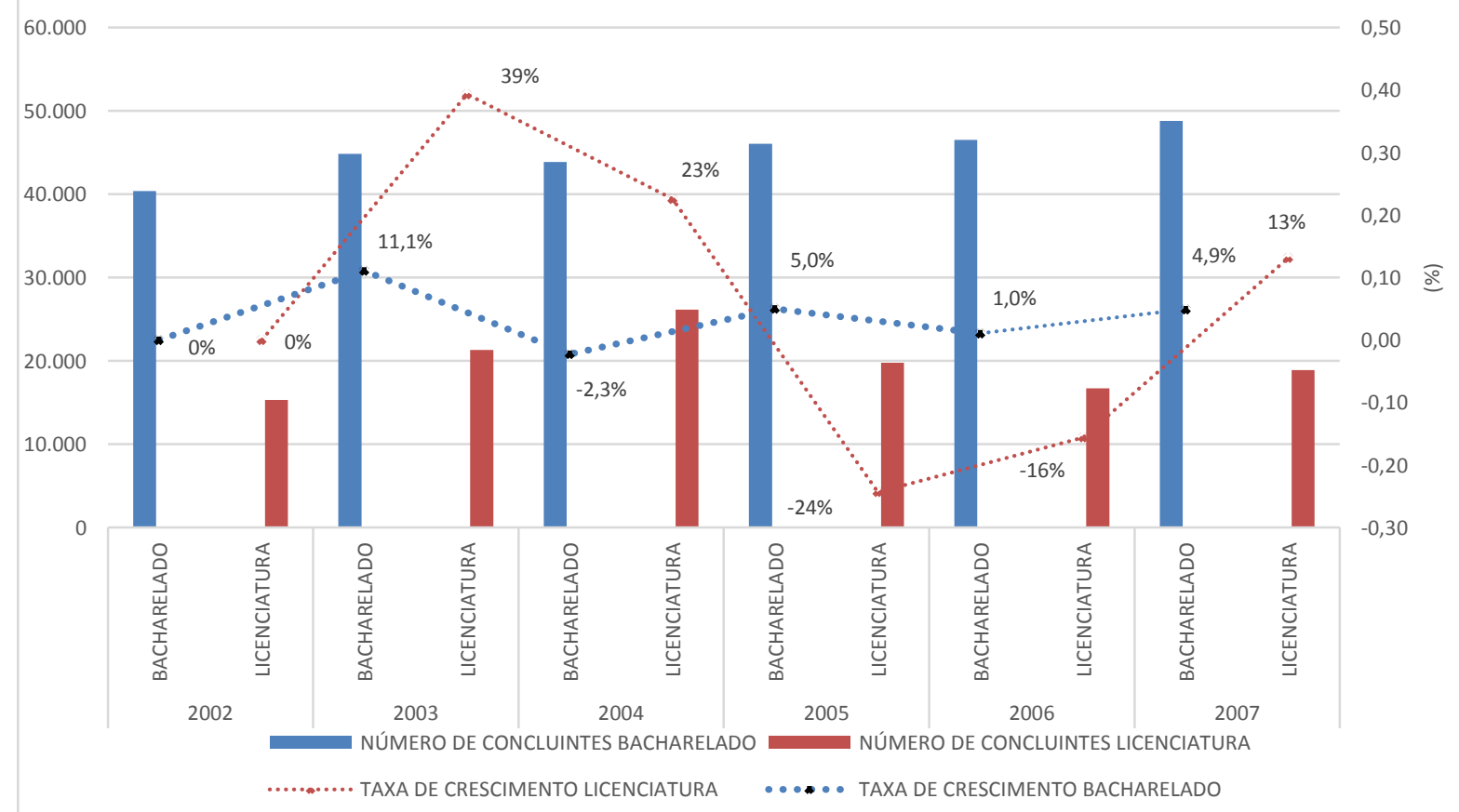

Fonte: Sinopse Estatística do Censo da Educação Superior de 2012 (INEP, 2012). Elaboração do autor. 
Embora não correlacionados, os fatores "professores sem qualificação mínima" e "baixa procura por cursos de licenciatura" podem impactar negativamente os resultados de aprendizagem do sistema público de educação básica do país. O baixo desempenho em avaliações internacionais, como o Programme for International Student Assessment (PISA) nos convidam a esta reflexão.

Como observam Gatti e Nunes (2009), o desempenho insatisfatório do país em avaliações nacionais e internacionais tem fomentado importantes debates sobre os fatores que implicam a melhoria da qualidade das escolas no país, sendo a formação de professores apontada como um fator de peso.

O governo parece ter se atentado para questões relativas à docência, pois acenou com ações de valorização da carreira profissional e da melhoria na formação de seus quadros. Um exemplo do primeiro ponto é a Lei n. 11.738/2008, que estabelece o piso salarial profissional nacional para os professores do magistério público da educação básica (BRASIL, 2008). Já a qualificação foi o alvo principal da última gestão do Ministério da Educação (MEC), quando uma miríade de iniciativas foi lançada para se fazer cumprir o disposto na LDB, tornando-a real. Tratava-se, e tratase ainda, de uma política pública, com seus componentes e desdobramentos. A Política Nacional de Formação de Profissionais do Magistério da Educação Básica, condensada no Decreto n. 6.755/2009, pretende aperfeiçoar a formação de professores para a educação básica por meio de um regime de colaboração entre União, estados, Distrito Federal e municípios (BRASIL, 2009).

O Governo Federal demonstrou intenção de efetivar a referida política por meio do lançamento de programas abrangentes, destinados a suprir de diversas formas a principal deficiência do professor brasileiro: a falta de formação adequada. Segundo o Censo Escolar de 2007, divulgado pelo Instituto Nacional de Estudos e Pesquisas Educacionais Anísio Teixeira (Inep), cerca de um terço dos professores brasileiros, ou 600 mil pessoas, não possui o nível superior requisitado pela própria LDB (INEP, 2009). A instituição encarregada de vencer esse desafio é a Coordenação de Aperfeiçoamento de Pessoal de Nível Superior (Capes), autarquia que conta com mais de meio século de experiência na formação de quadros de alto nível para atuação em universidades. 
Nesse contexto, é lançado em 2007 o Programa Institucional de Bolsa de Iniciação à Docência (Pibid), com a missão de contribuir para o aperfeiçoamento da formação para o magistério da educação básica por meio da inserção do estudante no espaço escolar durante dois anos de sua graduação, com recursos de apoio a atividades inovadoras.

Uma das iniciativas governamentais mais amplas de melhoria da qualidade da formação dos docentes da educação básica brasileiros, o Pibid se iniciou em 2009 com 43 instituições e três mil bolsistas e apresentou um forte crescimento, contando em 2013 com 45 mil bolsistas e 195 instituições participantes. Somado à Universidade Aberta do Brasil (UAB) e ao Plano Nacional de Formação de Professores da Educação Básica (Parfor), o Pibid pode ser considerado a própria implementação da Política Nacional de Formação de Profissionais do Magistério da Educação Básica.

Um indício de que os aprimoramentos de formação e carreira docentes adquiriram caráter de estado, para além de governo, são as previsões relativas às metas n. 15, 16 e 17 do Plano Nacional de Educação (PNE) 2014-2024 (BRASIL, 2014). Cabe lembrar que a nova edição sucede um planejamento que findou em 2010. Ou seja, durante quase quatro anos, as políticas continuaram a se orientar por um documento de vigência já expirada.

Conforme a meta n. 15, todos os professores deverão ter formação em licenciatura na área de conhecimento em que atuam, e essa formação deverá ser garantida por meio de um regime de colaboração entre União, estados, Distrito Federal e municípios. Para atingir o objetivo, são apresentadas 13 metas, dentre as quais duas se referem especificamente à formação prática na graduação:

[...] 15.3) ampliar programa permanente de iniciação à docência a estudantes matriculados em cursos de licenciatura, a fim de incentivar a formação de profissionais do magistério para atuar na educação básica pública.

15.9) Valorizar o estágio nos cursos de licenciatura, visando um trabalho sistemático de conexão entre a formação acadêmica dos graduandos e as demandas da rede pública de educação básica. (BRASIL, 2014).

Para além da formação em graduação, o PNE estabelece, na meta n. 16, que $50 \%$ dos professores da educação básica tenham formação em pós-graduação lato e stricto sensu:

[...] 16.1) Realizar, em regime de colaboração, o planejamento estratégico para dimensionamento da demanda por formação continuada e fomentar a 
respectiva oferta por parte das instituições públicas de educação superior, de forma orgânica e articulada às políticas de formação dos Estados, do Distrito Federal e dos Municípios.

16.2) Consolidar sistema nacional de formação de professores, definindo diretrizes nacionais, áreas prioritárias, instituições formadoras e processos de certificação dos cursos. (BRASIL, 2014).

Na meta 17 está apresentada a proposta de valorização da carreira docente por meio da aproximação entre o rendimento médio do professor com mais de onze anos de escolaridade e o rendimento médio dos demais profissionais com escolaridade equivalente:

[...] 17.2) Acompanhar a evolução salarial por meio de indicadores obtidos a partir da pesquisa nacional por amostragem de domicílios periodicamente divulgados pelo Instituto Brasileiro de Geografia e Estatística - IBGE.

17.3) Implementar, no âmbito da União, dos Estados, do Distrito Federal e dos Municípios, planos de carreira para o magistério, com implementação gradual da jornada de trabalho cumprida em um único estabelecimento escolar. (BRASIL, 2014).

Para o cumprimento dessas metas está previsto o aporte de $50 \%$ dos recursos recebidos pelo Fundo Social, resultante da exploração das jazidas de petróleo localizadas em profundidade de pré-sal (BRASIL, 2013).

\subsection{Como funciona o Programa Institucional de Bolsa de Iniciação à Docência}

O Pibid é um programa de aprimoramento do processo de formação de docentes para a educação básica (Educação Infantil e Ensinos Fundamental e Médio, para alunos dos 4 aos 17 anos de idade); seu objeto é o oferecimento de bolsas a projetos institucionais para que alunos de licenciatura exerçam atividades pedagógicas inovadoras em escolas públicas de educação básica, de modo a integrar teoria e prática de ensino e aproximar universidades e escolas.

Em suas atividades, os alunos de licenciatura são orientados por supervisores (professores de escola) e por coordenadores de área (docentes de licenciatura). Outro professor de licenciatura é o responsável pelo gerenciamento do projeto (coordenador institucional). Todos os participantes (coordenadores, supervisores e licenciandos) são bolsistas. A Figura 4 detalha os cinco perfis de participantes no programa: 
Figura 4 - Perfis de participação do Pibid

Iniciação à docência - estudantes de licenciatura das áreas abrangidas pelo
subprojeto. Valor da bolsa: $\mathrm{R} \$ 400,00$.

Coordenação de área - professores da licenciatura que coordenam subprojetos. Bolsa: $\mathrm{R} \$ 1.400,00$.

Coordenação de área de gestão de processos educacionais - professor da licenciatura que auxilia na gestão do projeto na IES. Bolsa: $\mathrm{R} \$ 1.400,00$.

Coordenação institucional - professor da licenciatura que coordena o projeto Pibid na IES. Bolsa: $\mathrm{R} \$ 1.500,00$.

Fonte: Elaboração do autor.

Todas as IES que ofertem cursos de licenciatura são elegíveis para o Pibid: podem participar tanto IES públicas quanto privadas sem fins lucrativos e privadas com fins lucrativos (estas devem ser participantes do Programa Universidade para Todos - Prouni). A implementação de um projeto institucional demanda uma série de articulações entre esferas administrativas, conforme o roteiro a seguir (Figura 5):

Figura 5 - Etapas da implementação do Pibid

$\begin{aligned} & \text { Publicação de chamada pública de projetos institucionais. Nesta chamada estão } \\ & \text { definidas as áreas de licenciatura elegíveis }\end{aligned}$
-Dirigente máximo da IES designa coordenador institucional (CI) do projeto,
responsável por elaborar o projeto

Fonte: Elaboração do autor. 
Embora seja uma política de formação inicial docente que prevê a inserção do aluno de licenciatura na escola, o Pibid não pretende substituir o estágio curricular obrigatório. Primeiro, porque não faz parte dos currículos; segundo, porque a regência de turma não pode ser realizada fora do período do estágio curricular, por questões legais. Nesse programa, os estudantes devem elaborar e executar atividades de cunho experimental e tendencialmente inovador, sendo vedada a regência de turma. São objetivos do programa:

I - incentivar a formação de docentes em nível superior para a educação básica;

II - contribuir para a valorização do magistério;

III - elevar a qualidade da formação inicial de professores nos cursos de licenciatura, promovendo a integração entre educação superior e educação básica;

IV - inserir os licenciandos no cotidiano de escolas da rede pública de educação, proporcionando-Ihes oportunidades de criação e participação em experiências;

V - incentivar escolas públicas de educação básica, mobilizando seus professores como coformadores dos futuros docentes e tornando-as protagonistas nos processos de formação inicial para o magistério;

VI - contribuir para a articulação entre teoria e prática necessárias à formação dos docentes, elevando a qualidade das ações acadêmicas nos cursos de licenciatura;

VII - contribuir para que os estudantes de licenciatura se insiram na cultura escolar do magistério, por meio da apropriação e da reflexão sobre instrumentos, saberes e peculiaridades do trabalho docente. (CAPES, 2013).

Logo, cada projeto Pibid deve contribuir com a formação prática para 0 exercício do magistério no sistema público de educação básica por meio de atividades que insiram os alunos bolsistas nas escolas. Como o objetivo maior é elevar a qualidade da educação pública, recomenda-se que as instituições desenvolvam as atividades do projeto tanto em escolas cujo Índice de Desenvolvimento da Educação Básica (Ideb) esteja abaixo da média nacional como naquelas que tenham experiências bem sucedidas de ensino-aprendizagem.

Os projetos são compostos por subprojetos, cada qual em uma área de licenciatura, prevista a interdisciplinaridade. Para auxiliar o desenvolvimento das atividades, está previsto o repasse de verbas de custeio e de capital - para despesas correntes e aquisição de equipamentos, respectivamente.

Conforme visto na seção anterior, o gerenciamento do Pibid está a cargo da Coordenação de Aperfeiçoamento de Pessoal de Nível Superior (Capes), fundação 
pública vinculada ao Ministério da Educação (MEC). Em 2007, a Capes recebeu a atribuição de desenhar e implementar políticas de formação de professores para atuação na educação básica - dentre as quais o Pibid - unificadas em 2009 na Política Nacional de Profissionais do Magistério da Educação Básica (BRASIL, 2009). A primeira chamada pública de projetos foi lançada no fim de 2007, e os primeiros projetos foram implementados em 2009.

Após sete anos de vigência, o Pibid apresenta uma expansão expressiva: em 2014, início de novos projetos, quase 90 mil bolsas foram pagas por meio do Sistema de Acompanhamento de Concessões da Capes (SAC), das quais mais de 65 mil são destinadas a licenciandos (CAPES, 2014). Em 2009, ano inicial de execução do programa, o número de bolsistas oriundos da primeira seleção - ocorrida em 2007 era de 3 mil bolsistas. Isso corresponde a um crescimento de aproximadamente 26 vezes no total geral de bolsistas em cinco anos.

Dentre os fatores concorrentes para tal crescimento, podem ser destacados a estabilização do programa e a flexibilização do acesso: na primeira seleção (CAPES, 2007) só se permitia a participação de IES federais; as seleções seguintes contemplaram IES estaduais, municipais e privadas (sem e com fins lucrativos). Nos anos de 2009, 2010, 2011 e 2013 houve mais seleções de projetos. Em 2010, houve chamadas que resultaram nas entradas de instituições privadas sem fins lucrativos e de licenciaturas ligadas à formação para a diversidade - cursos de educação do campo e de formação de professores indígenas (CAPES, 2010). Na edição de 2013, ingressaram instituições privadas com finalidade lucrativa participantes do Prouni (CAPES, 2013).

\subsubsection{Caracterização do Pibid como política pública}

Este trabalho adota a tipologia de políticas públicas proposta por J. Q. Wilson, segundo a qual as políticas devem ser compreendidas como uma relação entre a distribuição dos custos necessários à sua implementação e os beneficiados pelas iniciativas (SECCHI, 2011, p. 27). Conforme essa tipologia, o Pibid é uma política de caráter clientelista (client policy), pois os custos necessários à sua implementação 
estão distribuídos pelo conjunto da sociedade - no Pibid, os recursos para pagamento de bolsas são oriundos do orçamento da União; enquanto os benefícios gerados pelo programa são concentrados em grupos específicos: alunos de cursos de licenciatura, professores de escolas públicas de educação básica e professores de licenciaturas.

\subsubsection{Definição dos stakeholders}

Para a descrição completa de uma política pública, é necessário definir quem são seus stakeholders (SK) - pessoas envolvidas com o programa, a exemplo de financiadores, administradores, clientes dos programas, dentre outros (MERTENS; WILSON, 2012). Essa definição esclarece quem são os agentes envolvidos nas políticas, estabelece as atribuições de cada um e os relaciona hierarquicamente.

Considerando que o Pibid envolve diferentes níveis da esfera administrativa federal, estadual e municipal - o rol de SK é extenso, conforme o diagrama apresentado na Figura 6:

Figura 6 - Organização hierárquica dos stakeholders do Pibid

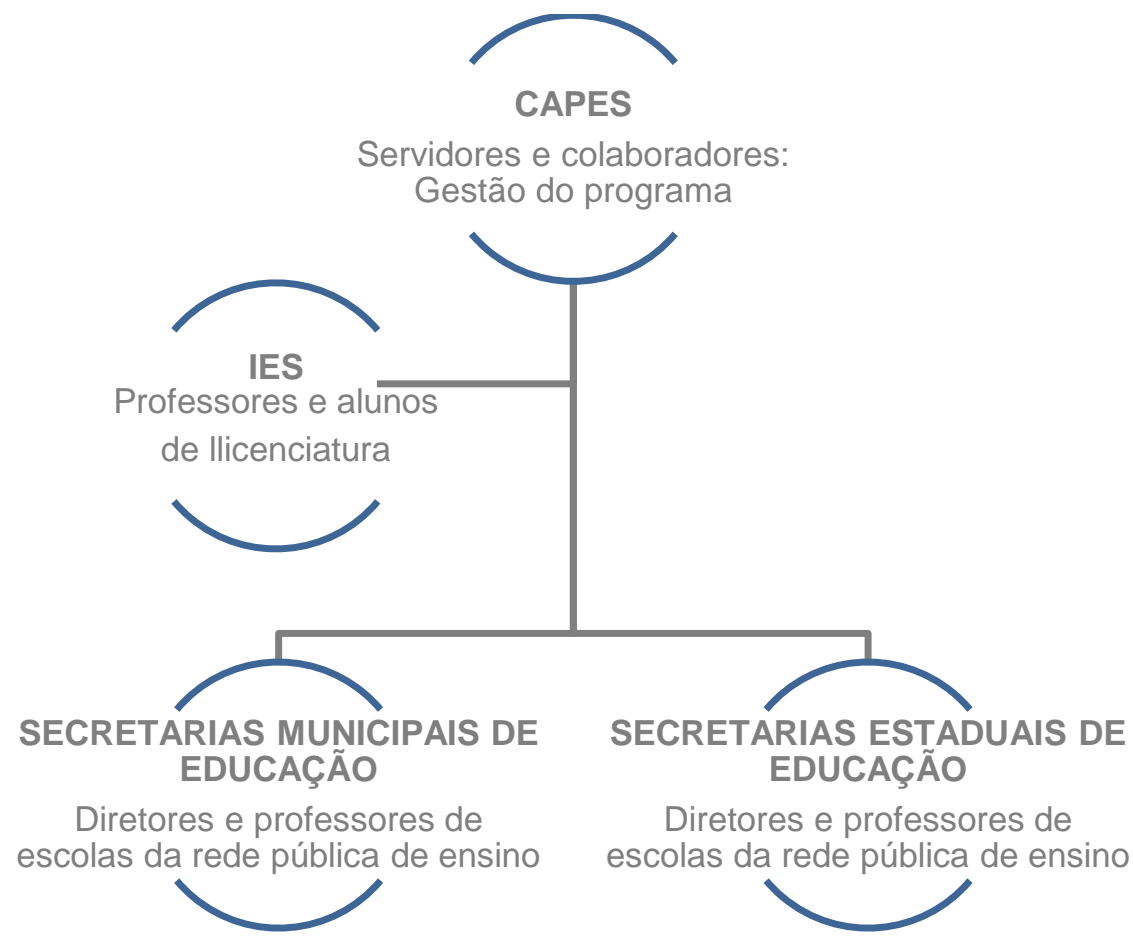

Fonte: Elaboração do autor. 
A Capes está no nível mais alto da hierarquia de SK, pois nela estão lotados os gestores do programa, especificamente na Diretoria de Formação de Professores da Educação Básica. No segundo nível se encontram as IES, nas quais atuam professores (gestores em nível institucional, que elaboram propostas, acompanham atividades e administram bolsas e recursos) e alunos das licenciaturas (público-alvo do Pibid, a ser detalhado adiante, em 1.2.4.). Na base estão as secretarias estaduais e municipais de educação, às quais estão vinculadas escolas (infraestrutura educacional), professores (coformadores dos licenciandos bolsistas) e diretores (gestores do espaço escolar). Essa hierarquia apenas relaciona as várias instâncias.

\subsubsection{Instituições implementadoras do Pibid}

O conjunto de instituições implementadoras do programa segue os níveis de SK apresentados acima. No topo está a Capes, a quem cabe o gerenciamento financeiro e administrativo do programa, por meio de seleção de propostas, pagamento de bolsas e supervisão administrativa. Logo abaixo estão as IES, responsáveis pela apresentação de propostas e sua execução - o que inclui firmar parcerias com as secretarias estaduais e municipais de educação para viabilizar a inserção dos estudantes de licenciatura no cotidiano escolar. No nível mais basilar estão as secretarias estaduais e municipais de ensino, a quem cabe colocar as IES em contato direto com as escolas, cuja estrutura será disponibilizada ao programa para o desenvolvimento das atividades.

\subsubsection{Público-alvo: a quem se destina o Pibid?}

O público-alvo do Pibid é composto pelos os estudantes de licenciatura e professores de escolas públicas de educação básica. A intenção é atrair os primeiros para um programa que propicie uma vivência do cotidiano escolar que vá além dos estágios supervisionados, possibilitando ao estudante uma imersão no ambiente da prática docente por meio do desenvolvimento de atividades inovadoras. 
Quanto aos professores das escolas de educação básica, o intuito é possibilitar a chance de contribuir com a formação de novos profissionais por meio do compartilhamento de experiências no âmbito da supervisão dos estudantes de licenciatura quando do desenvolvimento das atividades nas escolas.

\subsection{Justificativa e perguntas de pesquisa}

Ao descrever o problema público, no início deste capítulo, pontuamos que a formação de professores para atuação na educação básica brasileira passa por uma mudança de perspectiva em relação à prática do estudante na escola como parte fundamental de sua formação.

Conforme apresentado anteriormente, a finalidade do Pibid é apoiar a iniciação à docência de estudantes de licenciatura das instituições de educação superior públicas e privadas; seus objetivos são aprimorar a formação dos docentes, valorizar o magistério e assim contribuir para a elevação do padrão de qualidade da educação básica pública por meio do financiamento de projetos institucionais que promovam a inserção dos alunos de licenciatura no cotidiano das escolas públicas (CAPES, 2007). O intuito é fazer com que os alunos tenham um contato prolongado e aprofundado com o ambiente escolar durante sua formação, para além do estágio curricular obrigatório.

Todo este aparato institucional é recente; mas logo numerosas turmas de jovens professores formados terão passado pela experiência do Pibid e colocarão à prova a eficácia do programa em proporcionar um modo aperfeiçoado de prática docente. Após o período de estudo e a experiência de aproximação do meio escolar propiciados pelo Pibid, os novos docentes precisam estar prontos para atuar profissionalmente em escolas públicas.

A formação do futuro professor no Pibid reside no equilíbrio entre a proposta desenvolvida pelos coordenadores e apresentada à Capes e o cotidiano do subprojeto realizado, o que chamamos de aderência. Portanto, a pergunta que norteia esta pesquisa é: no ano de 2014, o subprojeto Pibid Física UnB realizou com sucesso 
a proposta de formação docente do Programa Institucional de Bolsa de Iniciação à Docência?

A escolha do subprojeto de Física se justifica pelo déficit de professores do Ensino Médio formados nessa disciplina. Segundo o Estudo Exploratório sobre o Professor Brasileiro (INEP, 2009), Física é a disciplina que possui o menor número de professores atuantes na educação básica com formação específica $(25,5 \%)$. Ao observar em detalhe a formação dos professores de Física, conforme dados de 2007, 34\% deles, ou seja, 44.566, têm, na verdade, formação em Matemática e são classificados como pertencentes a "outras áreas de formação"; os formados em Física correspondem apenas a 12.355 profissionais. Essa área é a que demanda mais esforços para atingir a exigência da LDB de que os docentes da educação básica tenham formação em nível superior em sua área de atuação.

Para responder a essa pergunta, precisamos encontrar respostas para as seguintes questões específicas: que objetivos são apresentados nos projetos? Quais metodologias de ação são propostas e quais são realizadas? Quais são os resultados esperados na proposta e efetivados no processo? Quais as ações propostas e quais são realizadas? Como ocorre a relação entre universidade e escola no cotidiano do subprojeto?

\subsection{Objetivo geral}

Esta pesquisa tem o objetivo geral de analisar objetivos, metodologias, ações, forma de relação entre universidade e escola e resultados esperados, presentes no relatório de atividades do subprojeto Pibid Física UnB relativo ao ano de 2014, para revelar convergências e divergências em relação à proposta de formação de professores do Programa Institucional de Bolsa de Iniciação à Docência.

\subsection{Objetivos específicos}

- Identificar, no subprojeto de Física do projeto Pibid da UnB, aprovado na seleção de 2013 da Capes: objetivos, metodologias, ações, forma de relação entre universidade e escola e resultados esperados. 
- Analisar, no relatório de atividades do subprojeto Pibid Física UnB do ano de 2014, os seguintes pontos: objetivos, metodologias, ações, forma de relação entre universidade e escola e resultados esperados.

- Destacar os pontos convergentes e divergentes entre os aspectos analisados nos documentos: projeto proposto e relatório de atividades do subprojeto Pibid Física UnB e os objetivos do Programa Institucional de Bolsa de Iniciação à Docência.

\subsection{Notas metodológicas}

Esta pesquisa busca interpretar se as proposições apresentadas e as atividades desenvolvidas do subprojeto Pibid Física UnB possuem realizam a proposta do Programa Institucional de Bolsa de Iniciação à Docência. Trata-se de uma pesquisa de caráter qualitativo, pois ocorre em um cenário natural; seus métodos são interativos e humanísticos; é "emergente", não estritamente pré-configurada, pois nossas questões podem se alterar, assim como a coleta de dados; é interpretativa, depende da própria situação do pesquisador com relação ao objeto estudado; e exige do pesquisador reflexão sistemática sobre quem ele é na investigação (RALLIS; ROSSMAN, 1998 apud CRESWELL, 2007).

Nosso ponto de vista é o de um componente da equipe técnica do Programa Institucional de Bolsa de Iniciação à Docência na Capes. Isso quer dizer que estamos envolvidos profissionalmente com nosso objeto, e todas as escolhas metodológicas e analíticas devem ser compreendidas pelo leitor deste trabalho como um "olhar da Capes" sobre o objeto de estudo.

A pesquisa proposta tem três etapas descritas em seguida:

1. Leitura de documentos regulatórios do Pibid;

2. Leitura da proposta do subprojeto Pibid Física UnB apresentada à seleção de 2013 da Capes;

3. Leitura do relatório de atividades do subprojeto Pibid Física UnB relativo ao ano de 2014;

4. Análise do material coletado. 
O trabalho de pesquisa se iniciou com a leitura das normas do programa: Portaria Normativa Capes n. 72, de 09 de abril de 2010; Decreto n. 7.219, de 24 de junho de 2010, que institui o Pibid; Portaria Pibid n. 260, de 30 de dezembro de 2010, que estabelece normas gerais (revogada); e Portaria Capes n. 96, de 18 de julho de 2013, o regulamento atual do Pibid.

Fizeram parte do corpus relatórios de gestão da Capes; relatórios de pagamentos de bolsistas, disponibilizados mensalmente desde agosto de 2013; termos de compromisso dos bolsistas; manuais de procedimentos (rotina de pagamento de bolsas, manual de usuário do Sistema de Acompanhamento de Concessões de Bolsas - SAC, orientações para cadastramento de bolsistas); orientações para troca de coordenação institucional; manual de devolução de bolsa; e formulário para substituição de coordenação institucional.

As etapas consistiram da leitura da proposta do subprojeto e do relatório de atividades - 0 ponto de interseção entre as realizações pedagógicas e 0 aspecto financeiro no Pibid. Esse foi o documento-chave para a compreensão do projeto, pois nele estão relacionadas as atividades realizadas ao longo de um ano e o consequente uso dos materiais adquiridos com a verba disponibilizada pela Capes aos projetos.

Esta pesquisa é um estudo de caso, pois foca o entendimento da dinâmica presente em configurações simples (EISENHARDT, 1989). Nossa intenção é compreender um fenômeno social complexo, contemporâneo, no qual estão pouco claras as fronteiras entre o fenômeno e o contexto. Temos de lidar com uma situação em que há mais variáveis de interesse que data points, ou pontos a partir dos quais vamos construir nossa análise. Como resultado, a pesquisa se orienta por múltiplas fontes de evidências (YIN, 2003).

Contra o estudo de caso se levanta uma série de restrições, dentre as quais podemos citar três das mais frequentes críticas endereçadas a essa abordagem (YIN, 2003): 1) falta de rigor metodológico, pois muitas vezes o investigador não adotou procedimentos sistemáticos, guiado por seu viés, encontrando evidências equivocadas; 2) reduzida possibilidade de generalização científica. De fato, não representa "amostras", mas sua razão de ser não é essa: trata-se de expandir e generalizar teorias (generalização analítica), e não de enumerar sequências 
estatísticas (generalização estatística) ${ }^{2}$; 3) duração excessiva, que resulta em documentos de extensão interminável.

Nem sempre estudos de caso precisam durar anos, pois não se confundem com métodos específicos de coleta de dados, como etnografias ou observações participantes. Preferimos a perspectiva de Stake (2012) ao entender que a subjetividade do pesquisador e os dados contraditórios estão presentes em pesquisas de quaisquer naturezas, sendo apenas mais facilmente apontáveis e identificáveis em estudos qualitativos.

Nossa pesquisa se concentra nas atividades de estudantes, professores da licenciatura e supervisores do subprojeto da licenciatura em Física, integrantes do projeto Pibid UnB aprovado na seleção de 2013 da Capes. Trata-se de um estudo interpretativo da aderência do subprojeto Pibid Física UnB aos objetivos do programa Pibid, tendo por referência o relatório de atividades do subprojeto relativo ao ano de 2014.

A análise dos dados foi feita em seis passos, alinhados à proposição de Creswell (2012): 1) coleta de dados; 2) preparação de dados para análise; 3) leitura do material; 4) codificação dos dados; 5) codificação do texto para descrição a ser usada na pesquisa; 6) codificação do texto para temas, ou categorias, a serem usados no relatório de pesquisa. Essas etapas são iterativas, e admitem um ciclo de retorno da fase final à inicial. Está envolvida aqui a análise simultânea dos dados à medida que forem coletados. Nisso reside outra diferença em relação à pesquisa propriamente quantitativa, na qual a coleta deve ocorrer anteriormente à análise (CRESWELL, 2012).

Lembramos novamente, concordando com Stake (2010), que não há fronteiras discretas definidas entre as abordagens. Trata-se de uma forma indutiva de trabalhar, partindo de dados detalhados (transcrições e notas) para códigos identificadores e agrupadores de conteúdos semelhantes. Buscamos identificar no subprojeto: objetivos, metodologias, ações, forma de relação universidade e escola e resultados esperados.

${ }^{2}$ Sobre a discussão em torno da generalização a partir de pesquisas qualitativas, conferir Eisenhardt (1989), Erisckson (2012), Flyvbjerg (2006), Rudding (2006) e outros. 
$\mathrm{Na}$ consequente fase de interpretação dos dados, cotejamos os elementos do subprojeto, identificados no relatório de atividades, com os objetivos do Pibid dispostos nos regulamentos da Capes. A partir desse confronto, aplicamos nosso conhecimento profissional adquirido na gestão do programa para compreender se o realiza com sucesso proposta do Pibid, e encerramos com uma discussão dos resultados. 


\section{ESTADO DO CONHECIMENTO - O QUE JÁ FOI PESQUISADO SOBRE O PIBID}

Neste capítulo, apresentamos o estado do conhecimento acadêmico sobre o Pibid. O levantamento foi realizado nos bancos de teses e dissertações da Capes, do Ibict e do portal Domínio Público. Também foram fonte de pesquisa os periódicos de qualificações Qualis A1 a B2. A busca compreende os anos de 2009 a 2013, de modo a abarcar todo o período de execução do programa.

Foram escolhidos trabalhos que contêm a palavra "Pibid" no título ou no corpo do texto, pois interessam a esta pesquisa apenas os estudos sobre o programa em si. Por isso, não foram buscados materiais com as palavras-chave "políticas públicas" e "formação de professores", pois nosso interesse aqui não reside na discussão do programa como política, mas na compreensão de como uma ferramenta de política pública é reconfigurada por seus agentes - designados pela sociedade. Tampouco integram o escopo desta investigação aspectos curriculares, comportamentais, cognitivos, antropológicos e filosóficos da formação docente. Outra palavra-chave não consultada foi "estágio supervisionado", ainda que seja possível abordar o Pibid da perspectiva da prática de aprendizado docente na escola. A preocupação deste trabalho reside apenas na dinâmica de implementação do Pibid.

Os textos recolhidos foram agrupados em cinco categorias, elencadas segundo a abordagem do autor sobre o programa: I) concepção de docência; II) conhecimentos adquiridos sobre a prática docente; III) discursos dos participantes sobre o programa; IV) pesquisas realizadas em grupos de participantes do Pibid; V) Pibid como política pública. Adiante, essas categorias serão detalhadas.

De 2009, ano que esta pesquisa considera como início do $\mathrm{Pibid}^{3}$, a 2013, foram publicados nove artigos em sete periódicos de conceitos Qualis A1 a B2: Antítese; Avaliação; Educação e Pesquisa; Linhas Críticas; Revista Sulamericana de Filosofia e Educação; Revista Teias; e Química Nova na Escola. A maior quantidade de artigos (cinco deles) abordou os discursos dos participantes do Pibid; outros três investigaram os conhecimentos adquiridos pelos participantes sobre a prática

\footnotetext{
${ }^{3}$ O primeiro edital do Pibid foi publicado em 13/12/2007, na pag. 40, seção 3 , do n. 239 do Diário Oficial da União. A seleção de propostas ocorreu em 2008, mas os projetos iniciaram suas atividades em 2009.
} 
docente; e um artigo discutiu o Pibid como política pública (Figura 7). A prevalência da categoria "discursos" pode ser atribuída às três publicações de estudos sobre relatos de sala de aula, realizados no programa de pós-graduação em Ensino de Ciências "Química da Vida", da Universidade Federal do Rio Grande - FURG.

Figura 7 - Quantidade de artigos sobre o Pibid, por categoria, por periódico, publicados de 2009 a 2013 em periódicos de conceitos Qualis A1 a B2

\begin{tabular}{|c|c|c|c|c|c|c|}
\hline \multirow[t]{2}{*}{ Periódico (Conceito Qualis) } & \multicolumn{6}{|c|}{ Categoria } \\
\hline & $\begin{array}{l}\text { Concepção } \\
\text { de docência }\end{array}$ & $\begin{array}{l}\text { Prática } \\
\text { docente }\end{array}$ & Discursos & Pesquisas & $\begin{array}{l}\text { Política } \\
\text { pública }\end{array}$ & Total \\
\hline Linhas Críticas (B1) & 0 & 1 & 0 & 0 & 0 & 1 \\
\hline Antíteses (B1) & 0 & 1 & 0 & 0 & 0 & 1 \\
\hline Rev. Sul. Fil. Ed. (B1) & 0 & 1 & 0 & 0 & 0 & 1 \\
\hline Química Nova na Escola (B2) & 0 & 0 & 3 & 0 & 0 & 3 \\
\hline Educação e Pesquisa (A1) & 0 & 0 & 1 & 0 & 0 & 1 \\
\hline Revista Teias (B1) & 0 & 0 & 1 & 0 & 0 & 1 \\
\hline Avaliação (B1) & 0 & 0 & 0 & 0 & 1 & 1 \\
\hline Total & 0 & 3 & 5 & 0 & 1 & 9 \\
\hline
\end{tabular}

Fonte: Elaboração do autor.

Em 2012 foi publicada a maior quantidade de artigos: cinco; seguido por 2011 e 2013, quando foram publicados dois trabalhos em cada ano (Figura 8).

Figura 8 - Quantidade de artigos sobre o Pibid, por categoria, por ano, publicados de 2009 a 2013 em periódicos de conceitos Qualis A1 a B2

\begin{tabular}{|c|c|c|c|c|c|c|}
\hline \multirow[t]{2}{*}{ Ano } & \multicolumn{6}{|c|}{ Categoria } \\
\hline & $\begin{array}{l}\text { Concepção } \\
\text { de docência }\end{array}$ & $\begin{array}{l}\text { Prática } \\
\text { docente }\end{array}$ & Discursos & Pesquisas & $\begin{array}{l}\text { Política } \\
\text { pública }\end{array}$ & Total \\
\hline 2013 & 0 & 1 & 1 & 0 & 0 & 2 \\
\hline 2012 & 0 & 1 & 3 & 0 & 1 & 5 \\
\hline 2011 & 0 & 1 & 1 & 0 & 0 & 2 \\
\hline 2010 & 0 & 0 & 0 & 0 & 0 & 0 \\
\hline 2009 & 0 & 0 & 0 & 0 & 0 & 0 \\
\hline TOTAL & 0 & 3 & 5 & 0 & 1 & 9 \\
\hline
\end{tabular}

Fonte: Elaboração do autor. 
De 2009 a 2013, 15 dissertações e teses defendidas tematizaram o Pibid. As abordagens preferidas pelos autores foram "conhecimentos adquiridos sobre a prática docente" e "discursos dos participantes sobre o programa", que geraram seis trabalhos cada; em seguida, encontrou-se um trabalho de cada uma das seguintes categorias: "concepção de docência", "impacto do Pibid nas escolas" e "profissionalização docente" (Figura 9).

Diferentemente do observado nos artigos, a quantidade de dissertações e teses sobre o Pibid parece aumentar a cada ano: após os primeiros trabalhos de 2011, seis estudos foram defendidos em 2012; de 2013 até o momento, oito pesquisas foram defendidas. Três trabalhos, datados de 2013, não tematizam o programa; limitam-se a realizar suas pesquisas em grupos de participantes do Pibid (Figura 9).

Figura 9 - Quantidade de dissertações e teses sobre o Pibid, por categoria, por ano, defendidas de 2009 a 2013

\begin{tabular}{|c|c|c|c|c|c|c|}
\hline \multirow[t]{2}{*}{ Ano } & \multicolumn{6}{|c|}{ Categoria } \\
\hline & $\begin{array}{l}\text { Concepção } \\
\text { de docência }\end{array}$ & $\begin{array}{l}\text { Prática } \\
\text { docente }\end{array}$ & Discursos & Pesquisas & $\begin{array}{l}\text { Política } \\
\text { pública }\end{array}$ & Total \\
\hline 2013 & 1 & 4 & 2 & 2 & 0 & 9 \\
\hline 2012 & 0 & 1 & 3 & 0 & 0 & 4 \\
\hline 2011 & 0 & 0 & 1 & 1 & 0 & 2 \\
\hline 2010 & 0 & 0 & 0 & 0 & 0 & 0 \\
\hline 2009 & 0 & 0 & 0 & 0 & 0 & 0 \\
\hline TOTAL & 1 & 5 & 6 & 3 & 0 & 15 \\
\hline
\end{tabular}

A seguir, apresentamos as discussões de cada trabalho. Os materiais estão agrupados em seções conforme as categorias de abordagem do Pibid identificadas e segundo o tipo de estudo (artigo pulicado em periódico, dissertação de mestrado ou tese de doutorado). Nos trabalhos, buscamos destacar objetivos, metodologias adotadas, resultados e descobertas e as conclusões dos autores. 


\subsection{Concepção de docência}

Nesta categoria, está representado um trabalho de mestrado que investiga o Pibid a partir da concepção de docência presente nos projetos. Entendemos "concepção de docência" como o debate existente na área da Educação sobre o modelo de formação do professor adotado por uma proposta educacional: se ele favorece a chamada "racionalidade técnica", segundo a qual o professor é um especialista que combina e aplica com rigor os conhecimentos científicos e pedagógicos assimilados em seu período de formação; ou se, de maneira oposta, privilegia a autonomia do professor, estimulando criatividade e reflexão em seu fazer cotidiano, aplicando "racionalidade prática" (DINIZ-PEREIRA, 1999).

Nos currículos dos cursos de licenciatura, costumam ser separados os conteúdos disciplinares dos pedagógicos em módulos que ocupam três anos e um ano, respectivamente. Conhecido por "modelo 3+1", esse arranjo é acusado de promover o afastamento entre teoria e prática e perpetuar a concepção de ciência dos sécs. XVII e XIX. Essa organização é a aplicação da racionalidade prática na formação docente em nível superior predominante no Brasil (GATTI, 2013).

A proposta do Pibid é expandir a parte prática da formação dos futuros professores por meio do fomento à inserção dos licenciandos nas escolas para desenvolver atividades tendencialmente inovadoras, ampliando seu contato com o cotidiano escolar. Nesses termos, o Pibid busca superar o modelo da racionalidade técnica, sem interferir nas Diretrizes Curriculares Nacionais. Mas é possível afirmar que os projetos institucionais aprovados nas seleções da Capes corroboram essa ideia?

Em sua dissertação, Garcia (2013) realiza análise documental de dez subprojetos de Química do Pibid 2007, dois por região do país, com o objetivo de determinar qual concepção de docência caracteriza cada projeto: racionalidade técnica ou racionalidade prática. $\mathrm{O}$ autor parte do pressuposto de que os subprojetos refletem as concepções de docência dos coordenadores de área, os quais teriam contado com "autonomia intelectual" na elaboração dos documentos. Nesse trabalho, 
os subprojetos não estão identificados por instituição, mas por uma sigla criada pelo autor: SQx, que significa subprojeto de Química, acompanhado de um número - 1 e 2 correspondem aos subprojetos da região Nordeste; 3 e 4, do Norte; 5 e 6, do CentroOeste; 7 e 8, do Sudeste; 9 e 10, do Sul. O método empregado é a interpretação dos textos dos subprojetos, com destaque para as ações propostas. O resultado do estudo aponta que quatro deles (SQ1, 89 e 10) apresentam concepções relacionadas à racionalidade técnica, enquanto seis (SQ2, 3, 4, 5, 6 e 7) podem ser caracterizados como de racionalidade prática.

Garcia (20130) inicia sua análise pelos projetos da região Nordeste (SQ1), de racionalidade técnica; e SQ2, de racionalidade prática. No texto do SQ1, classificado como de "racionalidade técnica", se encontra a ideia de que o estudante deverá dominar uma série de métodos para obter "sucesso" rumo a uma "Química perfeita"; suas ações têm como base os Parâmetros Curriculares Nacionais, que não levariam em conta particularidades regionais, por exemplo, e não estimulam os licenciandos a desenvolverem autonomia nem "senso crítico". Já o SQ2 é caracterizado como de "racionalidade prática", pois propõe articulação entre diversos ramos da Química, incentivo à reflexão crítica nas atividades experimentais e na investigação de conceitos químicos presentes em livros didáticos e produção de materiais didáticos.

Ambos da região Norte são de racionalidade prática. O SQ3 propõe pesquisa docente, estimula autonomia dos licenciandos e a realização de atividades experimentais. O texto do SQ4 propõe atividades coletivas, reflexão dos licenciandos sobre o fazer docente e ações voltadas para portadores de necessidades especiais.

Na região Centro-Oeste, os dois projetos analisados são caracterizados como de racionalidade prática. O SQ 5 abre espaço para que os estudantes identifiquem problemas e proponham soluções, além de estimular a pesquisa docente. No SQ6 está proposta a realização de pesquisa participante e o estímulo à adoção de posturas críticas.

Os projetos da região Sudeste são de racionalidade prática, no caso do SQ7; e técnica, no caso do SQ8. No SQ7 há a ideia de que profissionais docentes devem ter consciência de seu papel de formação de cidadãos, propondo práticas pedagógicas reflexivas e ações experimentais e lúdicas. No SQ8, as atividades já estão 
predeterminadas, bastando aos licenciandos aplicar as técnicas propostas, sem reflexão sobre os conteúdos do ensino médio a serem desenvolvidos na escola.

Ambos os subprojetos da região Sul são classificados como de racionalidade técnica. O SQ9 não faz referência aos licenciandos ao descrever a metodologia e não incentiva a tomada de decisões por parte deles. A falta de incentivo à reflexão também caracteriza o SQ10, o qual se restringe a trabalhar situações do cotidiano escolar.

Garcia (2013) conclui afirmando que todos os subprojetos se caracterizaram pela tentativa de articular saberes coerentes, mesmo apresentando propostas de trabalho distintas em relação à concepção de docência, e sua leitura aponta para a necessidade de reestruturar o modelo de formação brasileiro atual.

O fato de haver apenas uma dissertação sobre o tema "concepção de docência" e nenhum artigo publicado indica o reduzido interesse na discussão sobre concepção de docência no tocante ao programa. Esse tema demanda mais investigação, pois o estudo de Garcia (2013) traz evidências, mesmo limitadas pelo alcance da pesquisa, de que os projetos Pibid podem assumir um caráter de reprodução do modelo de racionalidade técnica, contrariando a proposta do programa.

\subsection{Conhecimentos adquiridos sobre a prática docente}

Esta categoria reúne trabalhos que abordam o Pibid como uma ferramenta de aprendizado das práticas cotidianas do professor em seu trabalho na escola pública de educação básica. $O$ interesse dos trabalhos a seguir é entender como o programa auxilia os estudantes de licenciatura na sua capacitação para o exercício da profissão de professor. Oito trabalhos compõem a categoria: três artigos, quatro dissertações e uma tese. 


\subsubsection{Artigos}

Resultado parcial de uma pesquisa, o artigo de Fabris e Oliveira (2013) analisa as práticas pedagógicas vivenciadas no Pibid para responder às seguintes perguntas: "o que os envolvidos no Pibid aprendem sobre docência?" e "em que lógica governamental estão ancoradas tais aprendizagens?" (p. 429). A metodologia empregada foi a aplicação de questionários direcionados a participantes do Pibid e a análise de blogs relacionados aos projetos. Os questionários foram aplicados em 61 bolsistas de iniciação à docência (ID) e em 17 supervisores; adicionalmente, foram analisados nove blogs publicados em 2010 e 2011. A intenção das autoras é esclarecer como discursos de outras áreas produzem verdades sobre a docência. Resultados preliminares da pesquisa apontam a existência de três grupos de enunciações a respeito das aprendizagens dos participantes sobre a docência no Pibid: Mobilização (1), Parceria e Trabalho Coletivo (2) e Inovação (3).

O grupo 1 tematizou a mobilização dos participantes. O estímulo às perguntas, às experiências, à participação, à integração e às atividades práticas mostra o quanto os atores envolvidos buscam deslocar as práticas para uma ação constante e sistemática, desacomodando a escola, o que lemos como deslocamentos de práticas passivas para práticas ativas, de práticas localizadas na sala de aula para práticas desenvolvidas em outros espaços. Esses textos apresentam práticas que conduzem a uma docência que "rompe com a rotina escolar e com os tempos e espaços escolares, buscando movimento" (FABRIS; OLIVEIRA, p. 439). Para as autoras, a mobilização referida nos discursos é efeito do conjunto de ações do Pibid, que movimentam universidade e escola. A "governamentalidade" derivada do programa é produtiva em fazer com que os participantes se movimentem para atingir os fins previstos pelo Estado. Por isso, é necessário fazer uma análise crítica das propostas de mobilização de cada universidade e cada área.

No grupo 2 se destacam a parceria e o trabalho coletivo entre universidade e escola. Essa parceria, segundo Fabris e Oliveira, manifesta uma ideia de "escola gerenciada" - segundo a qual escolas são geridas como empresas em uma lógica de mercado. A ênfase nas práticas da escola volta-se para a gestão. As ações do Pibid 
resultam em produção e economia; portanto se caracterizam como ações de inovação.

Para o grupo 3, é necessário buscar inovação; universidade e escola estão distantes, cabendo àquela a inovação no conhecimento. E, no atual estágio do capitalismo, o do conhecimento, o saber é a principal força produtiva; portanto, a busca por inovação se transfere da economia para a educação. Nesse sentido, a ênfase no trabalho coletivo é desresponsabilização do Estado sobre seus assuntos. A iniciação à docência a partir do material analisado coloca em funcionamento três tecnologias: a participação, a responsabilização dos sujeitos e a inovação.

Soares (2012) discute a relação entre o currículo da licenciatura em História e os currículos para o ensino médio observados entre turmas de alunos de licenciatura em História participantes do Pibid. Destaca a aproximação entre universidade e escola e as possibilidades de pesquisa, salientando que o Pibid não foi concebido exclusivamente para a investigação acadêmica. Coordenador do subprojeto História da Unifal, o autor desenvolveu uma pesquisa-ação na qual 14 bolsistas de iniciação à docência de História da Universidade são entrevistados sobre aspectos variados em relação aos currículos nas escolas estaduais e municipais em que atuam.

Os resultados são apresentados como conjuntos de opiniões. Para os participantes, o aprendizado dos bolsistas sobre a relação entre currículos prescritos e praticados ocorre na inserção nas escolas. A composição do currículo praticado seria afetada por alguns fatores: diretrizes da prescrição, avaliações externas, materiais didáticos, representações sociais em torno da escola e do conhecimento escolar, expectativas de aprendizagem dos docentes da escola e formação inicial e contínua.

Segundo os entrevistados, os professores das escolas parecem resistir a propostas de ensino alternativas ao livro didático, por se sentirem seguros ao se orientarem pelo livro. Além disso, a formação teórica dos licenciandos foi citada como fundamental para a inserção dos mesmos no cotidiano escolar e a reflexão sobre currículo decorre de sua formação teórica na graduação. Também seria preciso desenvolver melhor a informação das sequências didáticas sobre história africana para inseri-la adequadamente no contexto do período. Soares (2012) conclui pela 
necessidade de os participantes do Pibid conhecerem perspectivas teóricas sobre currículo.

Soares, Siqueira e Malaquias (2011), à época bolsistas de iniciação à docência do subprojeto Filosofia da UFBA, relatam haver aprendido a usar espaços extraclasse como a cozinha da escola, onde os alunos se reuniam antes das aulas. Trata-se antes de um relato de experiência, que não faz parte do escopo de nosso trabalho, e não um estudo. Sua permanência na categoria é justificada pelo fato de o texto haver sido publicado em periódico acadêmico de conceito Qualis abrangido por nossa pesquisa.

\subsubsection{Dissertações}

Correia (2012) afirma haver defendido a primeira dissertação sobre o Pibid ao lado de Tinti (2012). Produzido no grupo do programa Observatório da Educação na PUC-SP, o estudo pretende apresentar os conhecimentos evidenciados por licenciandos em Física e Matemática participantes dos subprojetos Pibid de Ciências Exatas na IES. As referências do autor, Mizukami (2002) e Fiorentini (2002), chamam a atenção para a diversificação da formação para além da inicial. A metodologia empregada por Correia inclui uma análise documental do relatório de atividades parcial do subprojeto Ciências Exatas e a participação do autor em um grupo de discussão durante a reunião semestral dos participantes.

Inicialmente, os participantes fizeram estudos teóricos sobre educação matemática; em seguida, aplicaram uma avaliação diagnóstica aos alunos de $6^{\circ}$ ano da escola, com o objetivo de auferir as dificuldades de aprendizado. A partir dos resultados, desenvolveram e então aplicaram "interferências" nas aulas das escolas.

As principais dificuldades apresentadas pelos alunos estavam relacionadas a área, frações, expressões numéricas e interpretação de enunciados das questões. Os resultados foram apresentados aos professores da escola, e atividades interventivas foram elaboradas conjuntamente durante reuniões. Essas atividades foram aplicadas em um período de seis semanas. O estudo abrange as duas primeiras de seis intervenções propostas, relativas ao conceito de área e à avaliação diagnóstica. 
O texto descreve as atividades do projeto encontradas no relatório de atividades e apresenta opiniões dos participantes coletadas em um grupo de discussão. Em sua conclusão, o autor afirma que o Pibid estimula os três tipos de conhecimento descritos por Shulman (1987): de conteúdo, pedagógico geral e pedagógico de conteúdo.

Feijolo (2013) se concentra na figura do supervisor e investiga 1) os tipos de saberes que o supervisor comunicou aos dois estudantes da amostra; 2) as relações com os saberes estabelecidas pelos estudantes de licenciatura. A metodologia de coleta de dados é a observação participante de uma equipe de dois licenciandos e um supervisor do Pibid, com gravação de vídeos dos encontros de preparação de atividades e realização de entrevistas. Os dados foram trabalhados por meio de análise de conteúdo, e os seguintes resultados foram encontrados: 1) saberes do supervisor sobre "planejamento dos conteúdos de aprendizagem"; "planejamento das atividades de aprendizagem", "planejamento do ambiente educativo" e "ensino explícito"; 2) saberes dos estudantes de licenciatura sobre planejamento e avaliação do ensino; identidade profissional; indisciplina dos alunos; reflexão docente.

Feijolo (2013) justifica sua escolha pelo Pibid com o fato de a estrutura do programa supostamente possibilitar a "socialização de saberes docentes" por meio da "interação entre licenciandos e supervisores". Para ele, o Pibid é um ambiente propício de interação entre o professor experiente e o estudante de licenciatura. Mas o estágio curricular também visa a aproximar aluno e professor. Então, por que escolher o Pibid? A escolha não está clara.

Martins (2013) realiza um estudo de caso sobre a relação entre as metodologias de ensino de Biologia desenvolvidas por sete egressos do curso de Ciências Biológicas da UFC, que participaram do Pibid entre 2009 e 2011, e sua formação pedagógica. Sua metodologia envolve entrevistas semiestruturadas e análise documental na coleta de dados; além de análise de conteúdo.

A autora apresenta ações desenvolvidas pelos participantes para o ensino do conteúdo; identifica as dificuldades do desenvolvimento dessas metodologias na escola e as estratégias para superar as adversidades; verifica como os participantes compreendem as metodologias de ensino durante sua formação e como o projeto 
influenciou sua prática pedagógica profissional; e ainda produz um material didático impresso com os ex-bolsistas. Sua conclusão é a de que o Pibid influencia a prática dos docentes, mas precisa ser articulado junto a uma política de valorização mais abrangente, que inclua melhoria das condições para o exercício da docência nas escolas, formação continuada e reestruturação de planos de cargos e salários.

Rocha (2013) tem como objetivo geral compreender como a experiência dos licenciandos em Ciências Sociais no Pibid intervém nos saberes da docência aprendidos por eles durante sua formação. $O$ autor entrevista e realiza grupos focais com dois professores e 14 licenciandos da Universidade Estadual do Ceará (UECE) com os seguintes objetivos específicos: refletir sobre os saberes da docência aprendidos na formação inicial de professores e sobre a contribuição da articulação entre teoria e prática nesse processo; conhecer as estratégias didático-pedagógicas do subprojeto Ciências Sociais para os saberes da docência aprendidos, e também aquelas reconhecidas pelos licenciandos como mais significativas para seu desenvolvimento profissional; identificar as situações de aprendizagens dos licenciandos no Pibid em relação aos saberes pedagógicos, curriculares, disciplinares e de experiência; e refletir sobre a contribuição do Pibid no processo de identificação profissional dos alunos do curso de licenciatura em Ciências Sociais.

Para 0 autor, seus resultados mostram que os licenciandos tiveram experiências de cunho reflexivo e inovador, nas quais a reflexão dos participantes teve como base a realidade da escola e a prática do docente no ensino médio. $\mathrm{Na}$ análise, identificou-se que os participantes do Pibid desenvolveram seis estratégias didático-pedagógicas: inserção do licenciando na escola de ensino médio; organização do grupo de estudo; estudos reflexivos; acompanhamento do professor supervisor; vivências de ministrar aulas pelos licenciandos; realização da pesquisaação.

No tocante à relação entre teoria e prática, os licenciandos demonstraram ter compartilhado experiências na elaboração de vários saberes docentes. Ao se referirem às aprendizagens desenvolvidas, os saberes da experiência foram os mais citados. Sobre a identificação profissional, os licenciandos expuseram dilemas pelo menos em três momentos: no primeiro, a dúvida quanto a seguir a carreira docente, 
especialmente ao assumirem a regência das classes; o segundo momento ocorreu pela ocasião que próprios licenciandos chamaram de "choque de realidade"; no terceiro, a aceitação de que ensinar é uma prática complexa.

Outro resultado da pesquisa mostra que o Pibid abriu maior espaço para abordar a "lógica da formação profissional" sem descuidar de conteúdos disciplinares. O texto conclui que o subprojeto de Ciências Sociais da UECE possibilitou a aprendizagem de saberes da docência pelos licenciandos, e que cada licenciando pôde extrair da experiência no projeto seus próprios usos. Na página 23, nota de rodapé n. 15, o autor se equivoca na descrição das IES elegíveis para o Pibid e omite o edital Diversidade, de 2010.

\subsubsection{Teses}

Sousa (2013) tem como objetivo compreender em que condições a prática docente é espaço de mobilização, elaboração e reelaboração de saberes sobre alfabetização. Nesse estudo de caso qualitativo, a autora usa como procedimentos de coleta de dados a análise documental, a observação e entrevistas semiestruturadas com três coordenadoras, duas supervisoras e cinco licenciandas participantes do subprojeto Pedagogia na PUC-RS.

A partir do método de análise de conteúdo de Bardin (1977), são identificadas na prática de ensino do Pibid três dimensões de saberes relacionadas à formação inicial do professor alfabetizador: saberes mobilizados, presentes no cotidiano dos encontros do Pibid, sem intervenções diretas dos supervisores ou coordenadores do projeto; saberes inicialmente refutados, encontrados no Projeto Político Pedagógico da Universidade, no projeto Pibid da IES aprovado pela Capes e nas falas das entrevistadas, mas não contemplados na ação de formação docente do projeto; e, por último, saberes elaborados e reelaborados, construídos a partir da intervenção das coordenadoras e supervisoras.

A autora enfatiza o caráter reflexivo da experiência docente. $\mathrm{Na}$ análise dos três saberes citados, o texto destaca o estudo da língua materna como um dos mais relevantes da formação em Pedagogia. Sousa (2013) observou que, por mais que se 
utilizem recursos pedagógicos de matriz construtivista, como jogos, o método predominante nos planos diários é fundamentado nas experiências das educadoras como alunas da educação básica, ou seja, em seus saberes da experiência anteriores à sua formação inicial de educadoras. Isso pode ser exemplificado por uma situação de alfabetização em que a professora tenta transmitir a língua como um código de transcrição de sons em formas visuais, limitando o aprendizado de língua ao domínio de um sistema codificado. Contudo, esses saberes da experiência apresentam o risco de se tornarem um quadro de referência estático, que dificulta a renovação da aprendizagem da docência.

Licenciandas, coordenadoras de área e supervisoras reportaram a fragilidade das disciplinas de prática de ensino da graduação em Pedagogia, e os saberes acadêmicos que preconizam articulação entre teoria e prática acabam por ser refutados na prática docente em detrimento dos saberes de experiência. Todos estes saberes são recombinados e reelaborados no cotidiano do Pibid, cuja proposta prevê a ação de figuras moderadoras do aprendizado. A conclusão do estudo afirma a tese de que o Pibid possibilita mobilização, elaboração, reelaboração e articulação dos saberes na e para a formação do professor da alfabetização, tornando-se referência para a organização das disciplinas Prática de Ensino ou Estágio Supervisionado.

Os trabalhos apresentados nessa categoria, todos qualitativos, se propõem a apresentar ou discutir quais conhecimentos sobre a prática docente foram adquiridos pelos participantes do Pibid. Existe uma variedade de focos dos estudos em relação aos participantes pesquisados: os artigos de Fabris e Oliveira (2013) e Soares (2012) e a dissertação de Correia (2012) abrangem licenciandos e supervisores, com destaque para os primeiros; Feijolo (2013) aborda os supervisores (metodologia qualitativa cuidadosamente elaborada); Martins (2013) estuda ex-bolsistas de iniciação à docência; Rocha (2013) envolve licenciandos e professores da IES (a maior parte do texto descreve o projeto institucional); e Sousa (2013) entrevista participantes de todos os níveis.

Contudo, apenas Feijolo (2013) tem uma preocupação específica com o supervisor, figura cuja atuação demanda mais atenção investigativa, por se tratar do coformador dos futuros professores, a figura que intermedeia a inserção na realidade 
escolar. Também merecem mais estudos os ex-bolsistas de iniciação à docência, pois a compreensão dos rumos profissionais dos novos docentes torna possível uma avaliação dos outcomes (resultados de curto prazo) do programa: após a experiência do Pibid, os novos professores tiveram um ganho qualitativo em sua prática docente? Mais pessoas se interessaram pela carreira docente? Quantos permaneceram na carreira, e por quê? Qual a motivação dos desistentes?

Os trabalhos se aproximam no que diz respeito aos instrumentos de coleta e análise de dados empregados: análise documental, entrevistas; e análise de conteúdo, respectivamente. Notamos que todos os estudos buscam definir os conhecimentos adquiridos pelos participantes a partir de entrevistas ou grupos focais ou observações, o que mostra uma preocupação dos autores com as opiniões dos participantes em relação às atividades desenvolvidas no projeto.

\subsection{Discurso dos participantes sobre o programa}

Nesta categoria encontram-se 11 trabalhos - cinco artigos e seis dissertações - que buscam compreender percepções e opiniões dos participantes do Pibid sobre sua experiência nos projetos. Essa é a abordagem do Pibid que reúne a maior quantidade de trabalhos levantados para nosso estudo.

\subsubsection{Artigos}

Albuquerque e Galiazzi (2013) analisam 220 histórias de sala de aula produzidas mensalmente por 11 licenciandos do subprojeto Pibid Química da Universidade Federal do Rio Grande (Furg), de 2009 a 2010, para defender que os relatos contêm conteúdos produtores de currículos para os cursos de licenciatura em Química. Para as autoras, o Pibid representa uma oportunidade de aproximação reflexiva entre alunos da licenciatura e professores das escolas por meio da produção de relatos na chamada Roda de Formação. Trata-se de um ambiente no qual os participantes do programa produzem portfólios coletivos (escrita do professor da 
educação básica com os licenciandos que atuam na escola), histórias de sala de aula e produção de materiais didáticos.

Usando a metodologia da Análise Textual Discursiva, o texto conclui que 115 relatos continham quatro conteúdos passíveis de serem trabalhados em cursos de licenciatura, a saber: 1) desarticulação entre universidade e escola, no qual os alunos demonstraram dificuldades em reconhecer as possibilidades de ambos os espaços formativos; 2) sala de aula, ou a relação com alunos das escolas; 3) avaliação, compreendida como instrumento de poder do professor e momento de fragilidade dos alunos, que necessita de critérios cuja natureza é de difícil definição; 4) caso da educação, no qual se aborda a desvalorização da profissão e a desmotivação dela derivada.

Dornelles e Galiazzi (2012a) analisam em seu artigo 48 histórias de sala de aula produzidas por seis professoras do ensino médio, supervisoras do subprojeto Pibid de Química da Universidade Federal do Rio Grande (Furg) em 2009, e publicadas no ambiente virtual de aprendizagem do projeto na plataforma Moodle. As autoras afirmam que a escrita narrativa, ao ser realizada em rodas de formação, possibilita a partilha de experiências e o repensar das práticas educativas na sala de aula de Química.

A metodologia empregada é o "quinteto dramatístico" de Burke (1969). Sua questão de pesquisa é "o que narram sobre a sala de aula as histórias de professoras de Química nas rodas de formação do Pibid?" (DORNELLES; GALIAZZI (2012a). A partir da análise, foram elencadas sete categorias: 1) primeiras histórias da roda; 2) situação-problema com enfoque ciência-tecnologia-sociedade; 3) processo formativo do professor com o licenciando; 4) parceria do professor com o licenciando nas atividades experimentais; 5) questionamentos e desafios da sala de aula de Química; 6) narrando a si mesmo em outro professor; 7) sala de aula de Química na ação de planejar e avaliar. $O$ artigo analisa as categorias 4 e 7 e conclui que avaliação e planejamento precisam ser discutidos em um contexto de articulação entre universidade e escola. Essa articulação também proporciona o desenvolvimento de "práticas pedagógicas diferenciadas", como as atividades experimentais. 
Fetzner e Souza (2012) apresentam os resultados iniciais de sua pesquisa sobre as concepções de conhecimento escolar presentes nos saberes docentes de professores supervisores e de licenciandos participantes do projeto Pibid da Universidade Federal do Estado do Rio de Janeiro (Unirio). As autoras reconhecem como um desafio para muitas escolas do ensino fundamental reconhecer e trabalhar conhecimentos significativos para seus frequentadores na perspectiva da interculturalidade.

O questionamento da pesquisa foi suscitado pelas dúvidas dos licenciandos, que pareciam se preocupar em como fazer os alunos da escola aprenderem os conteúdos, em detrimento de por que deveriam aprendê-los. A metodologia empregada envolveu a aplicação de um questionário, em maio de 2011, aos 36 licenciandos dos três subprojetos - Ciências, Pedagogia para o Ensino Fundamental (EF) e Pedagogia para o Ensino Médio (EM).

Até o momento do artigo, 21 licenciandos haviam respondido ao questionário oito de Ciências; quatro de EF; e nove de EM. Dentre eles, 19 tinham entre nove e 12 meses de participação no projeto; e dois participavam há menos de dois meses.

O questionário perguntou o que o Pibid representa em termos de formação integral do professor, levando em conta os saberes práticos profissionais e os saberes acadêmicos. Nos resultados da pesquisa, os bolsistas de Ciências afirmaram haver integração entre os saberes acadêmicos e práticos, especificamente no saber da disciplina; as bolsistas que desenvolvem atividades no EF afirmaram integrar saberes universitários e docentes aos saberes dos alunos propostos pela escola; já para os bolsistas ligados ao EM, merecem destaque a pesquisa desenvolvida por meio do Pibid e a relação de algumas disciplinas do curso de Pedagogia com o cotidiano escolar.

Mello (2011) apresenta seis meses de experiência como coordenadora de área do subprojeto Pedagogia da Universidade Federal Fluminense - UFF em uma turma de jovens de nove a quinze anos de uma escola da rede estadual localizada em Niterói, RJ. Com um histórico de baixo rendimento, os alunos da turma são conhecidos pela resistência a iniciativas pedagógicas, notadamente àquelas propostas pela universidade. Após apresentar reflexões sobre o papel do diálogo, a 
autora conclui apresentando o incentivo à prática da leitura como alternativa para lidar com o problema. Trata-se de um relato de experiência, incluído aqui por haver sido publicado em periódico.

Stanzani, Broietti e Passos (2013) investigam se os objetivos do Pibid estão sendo contemplados pela prática de iniciação à docência do subprojeto de Química da Universidade Estadual de Londrina (UEL). Sua metodologia é o acompanhamento de um grupo de seis bolsistas de iniciação à docência do projeto aprovado na seleção de 2011 durante o planejamento e a execução de algumas atividades. Posteriormente, foram aplicadas entrevistas semiestruturadas, as quais seguiram a organização relatada por Szymanski (2004): questões básicas acerca do tema da pesquisa, Pibid e formação inicial; em seguida, os depoimentos foram transcritos e analisados segundo a abordagem da análise de conteúdo.

Os depoimentos foram agrupados em seis categorias, a partir dos objetivos do programa, quais sejam: incentivo à formação docente; valorização do magistério; integração entre ensino superior e educação básica; prática no ambiente profissional; papel do professor supervisor/coformador; e articulação entre teoria e prática. Os autores concluem que os objetivos do Pibid são atingidos pelo projeto, pois o programa permite aos licenciandos uma formação fundamentada na reflexão sobre situações reais da prática profissional. Nos relatos, as relações entre os participantes aparecem como fatores que concorrem positivamente para a formação da identidade docente; esse ambiente promove reflexões acerca do conhecimento sobre Química a partir de uma perspectiva pedagógica, na qual experimentação e contextualização são essenciais.

\subsubsection{Dissertações}

Cruz (2012) tenta compreender como o projeto Pibid se constitui em dispositivo produtor de práticas discursivas sobre o ensino de Filosofia. Suas perguntas de pesquisa são: como o subprojeto Filosofia se constitui em dispositivo de práticas docentes? Como se configuram as concepções de Filosofia e de seu ensino por meio do projeto? Como caracterizar a proposta quanto aos processos de experenciação e 
subjetivação? Como as práticas docentes se efetivam enquanto exercícios de pensamento e possibilidades de resistência ao ensino "bacharelizado" de Filosofia? A metodologia adotada pela autora inclui: análise documental da regulação do ensino de Filosofia; descrição do projeto Pibid Filosofia, com destaque para as atividades relacionadas a cinema, teatro, leitura e escrita filosóficas; descrição e análise de entrevistas realizadas com seis bolsistas, que participaram do programa de 2010 a 2011.

Em relação ao ensino do curso de licenciatura, os bolsistas pesquisados revelaram descontentamento no que diz respeito à desvinculação entre as disciplinas teóricas e as voltadas à escola; e ao contato tardio com a escola. Os aspectos do subprojeto Filosofia que possibilitam seu entendimento como dispositivo são "a evolução enquanto estudante"; a não separação entre pesquisador e estudante em um curso de licenciatura; a "legitimação" dos cursos de formação de professores; a possibilidade de inserção efetiva e antecipada no ambiente da escola; o caráter de pesquisa e extensão; e a experiência do espaço escolar antecipada ao estágio supervisionado. A autora conclui com a observação de que uma das grandes dificuldades iniciais do subprojeto foi a de organizar o trabalho em grupo, uma vez que o ambiente do ensino de Filosofia se encontrava acostumado ao exercício do trabalho individual.

Dorneles (2011) analisa 48 histórias de sala de aula publicadas mensalmente por seis professoras supervisoras do projeto Pibid Furg nas chamadas "Rodas de Formação", ambiente virtual de discussão criado na plataforma Moodle, com o objetivo de compreender a formação permanente das docentes. Em relação às histórias, mais especificamente, o trabalho se propõe a perceber suas características, investigar a articulação entre supervisor e licenciando, levantar dilemas e questionamentos sobre a sala de aula e entender o planejamento e a avaliação das professoras.

A autora se propõe a compreender as narrações por meio da metodologia do "quinteto dramatístico" de Burke (1969), para a qual toda narração pode ser dissecada analiticamente em cinco elementos: cena - onde e quando ocorre a história; instrumento - como foi feita; propósito - por que foi narrada; ato - o que foi narrado; e 
agente - personagens presentes no relato. Essas categorias foram buscadas em cada relato das professoras.

Dorneles (2011) aproximou aquelas de mesmos motivos, ou propósitos, e elencou categorias por títulos que remetem à metáfora do bordado: ponto de elos, ou primeiras histórias; ponto triangular, apresentação de situações-problema; ponto trançado, ou processo formativo do professor com o licenciando; ponto de entremeio, ou tempo disponível para atividades experimentais; ponto cruz, ou dilemas das docentes; ponto cruz duplo, ou formação de si no outro professor; e ponto entrelaçado, ou ações de planejamento e avaliação. Em seguida, o autor expõe os elementos de cada categoria.

$\mathrm{Na}$ categoria "Ponto de Elos", estão presentes os desafios do início da docência; o valor de uma proposta pedagógica e do planejamento de aulas criativas; a necessidade de participar de um grupo de formação permanente; a importância de discutir a gestão escolar; e a frustração pela quebra de expectativas em relação à realidade da escola. No Ponto Triangular, foram descritos os desenvolvimentos de atividades nas escolas, parte em que se destaca o diálogo entre docentes e alunos como possibilidade de construção das atividades.

Dentro de "Ponto Trançado", a autora defende a consolidação da formação permanente de iniciativas semelhantes ao Pibid para o fortalecimento da relação entre licenciandos e alunos da educação básica. Em "Ponto de Entremeio", as parcerias entre professores e licenciandos tornam possíveis atividades experimentais, que, de outra forma, seriam de difícil realização, pois o tempo dos docentes para a preparação das atividades é exíguo.

Em "Ponto Cruz", Dorneles percebe a necessidade de construir espaços de formação continuada que envolvam professores das escolas e da universidade, enquanto a parte "Ponto Cruz Duplo" destaca a necessidade de narrar histórias em conjunto para efetivar seu potencial em sala de aula. Em "Ponto Entrelaçado", o estudo teórico surge como necessidade nas narrativas, o planejamento decorrente da teorização se torna mais consistente e se torna possível compreender e transformar o ensino de Química. Dorneles (2011) conclui afirmando que as Rodas de Formação 
analisadas potencializam a atuação do professor como pesquisador, em um processo de formação permanente que leva à ressignificação do ensino da disciplina.

Moura (2013) se propõe a compreender o espaço de formação proporcionado pelo Pibid aos alunos do curso de licenciatura em Matemática da Universidade Federal de Uberlândia (UFU) incluídos no projeto. A metodologia adotada é a observação participante das atividades de nove licenciandos em uma escola e na universidade no período de 2011 a 2012. Seus instrumentos são notas de campo, registros fotográficos e filmados, análise documental, questionários e entrevistas. Os eixos da análise de dados são: apresentação do processo de constituição de espaços de formação, produção e capacitação profissional, produção de saberes e integração do Pibid a outros espaços de formação do curso de licenciatura.

No primeiro eixo, denominado "Trajetória do Grupo", foram destacadas as seguintes características do trabalho: abertura para a contribuição de todos os interessados, independentemente de fazerem parte do Pibid; e integração entre os participantes, o que gerou uma "cultura favorável" ao programa na escola e favoreceu a produção dos alunos.

No segundo eixo, denominado "Processo de produção dos pibidianos no cotidiano da escola pública", Moura (2013) discorre sobre os produtos dos licenciandos no projeto a partir da leitura do relatório de atividades. Nesse ponto, o autor percebe que os licenciandos se fundamentam em textos mais gerais sobre as questões observadas na escola, e as atividades resultantes tentam se orientar pela leitura - o que, muitas vezes, gera resultados distantes dos previstos. Além disso, a pesquisa docente foi estimulada e gerou a participação dos licenciandos em eventos ligados ao ensino de Matemática.

Segundo Moura (2013), o trabalho com alunos de baixa renda desafia os licenciandos, que procuraram desenvolver produções estimulantes, como oficinas de robótica, e houve uso de diversos espaços da escola, somado à utilização frequente de tecnologias de informação e comunicação (TIC). O autor observou também que, nos discursos dos licenciandos, são citadas evoluções em habilidades diversas, como expressão, autonomia e criatividade. 
No terceiro eixo de análise, denominado "A integração do espaço de formação do Pibid com a licenciatura em Matemática", o autor propõe a inserção do Pibid como espaço institucional de formação na licenciatura em Matemática da UFU, ao lado do Núcleo de Formação Pedagógica e do Estágio Supervisionado; mas com o adicional de ser o articulador entre os espaços. Moura (2013) afirma que o trabalho coletivo é a chave para o reforço da formação docente na licenciatura em Matemática na UFU.

Souza (2013) pretende apontar quais representações de alunos da escola estão presentes nos discursos do grupo do subprojeto Letras/Inglês da Universidade Estadual de Londrina (UEL) e que mudanças discursivas sobre essas representações ocorrem durante o período da pesquisa. A metodologia adotada é a análise de gravações em áudio realizadas em 2010, relativas a 17 reuniões de um grupo de estudos composto pela própria autora, pela coordenadora de área, por uma professora voluntária que atuava em função análoga à de coordenadora, e por nove licenciandos de terceiro e quarto anos do curso.

A autora usou as categorias da análise de discurso crítica "responsividade", "ativação/passivação" e "transitividade" para responder à pergunta sobre os sentidos das representações. Ao analisar os processos de sentido quanto às ações, reuniu os discursos nas categorias "modalização", "mitigação", "avaliação" e "metáfora".

$\mathrm{Na}$ descrição de seus resultados quanto às representações identificadas, Souza (2013) percebe identificações entre professores e alunos, mas também separação conflituosa; por vezes, alunos são reificados no discurso sobre sua capacidade de "receber" conhecimento. A perspectiva colaborativa do subprojeto acaba por se fazer presente nas representações e os alunos passam a figurar como ativos na construção de conhecimento; por conseguinte, as falas dos participantes aludem à "união", à "experenciação" do aprender por parte de docentes e discentes nas escolas. A autora conclui apontando como principal contribuição do Pibid a promoção de colaboração entre os agentes do conhecimento, com redução das distâncias entre alunos e professores.

O estudo de Stanzani (2012) tenta identificar as contribuições do Pibid à formação de professores de Química da UEL. Sua proposta metodológica consiste em acompanhar os ID em suas atividades ligadas ao Pibid na universidade e nas 
escolas e entrevistá-los a respeito do processo de formação inicial. Os dados foram em seguida trabalhados por meio da análise de conteúdo (BARDIN, 2004).

Inicialmente, o autor teve dificuldades para coletar dados nas escolas, pois SUP apresentaram resistência à sua presença no ambiente, e tanto ID quanto SUP se mostraram receosos em relação à gravação de aulas e entrevistas. Esse contratempo levou o autor a trabalhar com 11 novos bolsistas, ingressos em uma edição seguinte do projeto, iniciada no segundo semestre de 2011. O autor começou acompanhando as atividades de cinco ID e um SUP por um semestre; no primeiro semestre de 2012, foi a vez dos outros seis ID e do SUP que os auxiliou. Do primeiro grupo, quatro ID foram entrevistados; já no segundo, apenas três, pois os demais não haviam ainda participado de atividades. Alguns resultados parciais foram sistematizados em artigo submetido para a revista "Química Nova na Escola", apresentado acima.

Nos relatos apresentados, está presente o impacto positivo do Pibid na formação dos licenciandos, notadamente no tocante à possibilidade de vivenciar o cotidiano escolar. Participar do programa acrescenta motivação pela carreira docente e ajuda na construção de uma ideia de profissional. A relação entre universidade e escola torna-se mais estreita, e ambas são beneficiadas em um processo de articulação entre teoria e prática. As opiniões coletadas permitem ao autor concluir que os objetivos do Pibid são realizados no subprojeto em questão.

Tinti (2012) investiga as contribuições da fase inicial do subprojeto Pibid Exatas da PUC-SP para a formação inicial de três licenciandos dos cursos de Matemática e Física da instituição, os quais compõem o subprojeto. Com base em suas referências sobre formação inicial, o autor afirma não ser o Pibid um programa de iniciação à docência, pois está voltado para o período de "pré-docência", de formação, e não de introdução no cotidiano profissional.

Nesse estudo foram realizadas entrevistas semiestruturadas com os licenciandos participantes. Para atingir o objetivo, a pesquisa, integrante de projeto do programa Observatório da Educação, tenta responder às seguintes questões: 1) quais foram as ações iniciais desenvolvidas no âmbito do subprojeto Pibid Exatas? 2) Quais foram as percepções dos bolsistas sobre as ações iniciais desenvolvidas? 3) Com 
base nessas percepções, quais foram as contribuições do subprojeto Pibid Exatas da PUC-SP para o processo formativo dos alunos?

$\mathrm{Na}$ investigação, foram escolhidos os licenciandos que participaram do projeto desde sua implementação em 2010: dois homens de 32 e 49 anos e uma mulher de 42 anos. Com duração média de 35 minutos, as entrevistas foram realizadas no primeiro semestre de 2011, em datas diferentes. A pesquisa se concentrou na primeira ação desenvolvida no subprojeto: o conhecimento da realidade da escola em que os licenciandos desenvolveriam suas atividades. Nessa etapa, os bolsistas ID deveriam identificar os aspectos físico, pedagógico e humano da escola, além de relacioná-los por meio de uma análise sintetizada em um documento a ser entregue aos gestores das escolas.

O autor analisou as transcrições das entrevistas a partir de sete categorias, estabelecidas com base nas referências do autor sobre formação inicial e políticas de formação de professores: 1) Conhecimento da Escola - os licenciandos perceberam diferenças entre escolas estaduais e municipais e demonstraram compreender o valor da gestão escolar para o sucesso do aprendizado; 2) Trabalho Colaborativo e Vivência Interdisciplinar, ou experiências de trabalho conjunto entre licenciandos e seus colegas de curso, professores da universidade, das escolas e supervisores, além de iniciativas de integração de conteúdos; 3) Parceria Universidade-Escola, na qual os licenciandos demonstraram não perceber o Pibid como uma iniciativa de parceria; 4) Formação Inicial com vistas a Minimizar o "Choque com a Realidade", em que os bolsistas afirmaram haver superado preconceitos em relação à prática docente; 5) Atratividade da Carreira Docente, na qual se pode perceber a insegurança em relação à profissão; 6) Recursos Metodológicos no Ensino da Matemática, sem menções nos relatos - situação atribuída pelo autor ao recorte da pesquisa, que é a fase de conhecimento da escola; 7) Incentivo e Inserção no Universo da Pesquisa Científica, também sem relatos nas entrevistas, ao contrário das expectativas do autor.

Ao concluir, Tinti (2012) afirma haver confirmado sua hipótese, segundo a qual as ações iniciais do Pibid contribuíram para a superação de preconceitos sobre 0 
sistema público de ensino, tornaram a carreira docente mais atrativa e minimizaram o "choque" da inserção no cotidiano profissional.

Os estudos apresentados têm em comum a impressão positiva sobre o programa transmitida nos resultados das pesquisas: para os participantes, o Pibid gera discussões cujos conteúdos podem integrar cursos de licenciatura (ALBUQUERQUE; GALIAZZI, 2013); desperta o debate sobre avaliação e planejamento (DORNELLES; GALIAZZI, 2012a); promove a prática da pesquisa e a integração entre saberes teóricos e práticos, saberes universitários e dos alunos da escola (FETZNER; SOUZA, 2012); favorece a formação baseada na reflexão sobre situações reais da prática profissional (STANZANI; BROIETTI; PASSOS, 2013). Trabalho coletivo é enfatizado por Moura (2013) e Souza (2013) e dificuldades no desenvolvimento do projeto são apresentadas por Cruz (2012).

Não apenas elogios estão presentes nas discussões, mas também a própria natureza conceitual do programa, seu estatuto. O Pibid se afirma como um programa de fomento à iniciação à docência, mas talvez seja adequado classificá-lo como uma iniciativa de apoio à pré-docência, pois está voltado para a etapa de formação do futuro profissional docente (TINTI, 2012).

As opiniões dos participantes levantadas pelos estudos apresentados nessa categoria apresentam elementos para a compreensão do programa a partir da perspectiva dos integrantes dos projetos Pibid. A metodologia da análise do discurso caracteriza os trabalhos, que buscam aproximação qualitativa de seus objetos. Com o material coletado por esses estudos, é possível tentar compreender os resultados e a metodologia pode ser usada em avaliações do programa. Contudo, outros índices podem traduzir a sua influência e seu alcance; por exemplo, no caso dos estudos que interagem com o Pibid, mas não estudam o programa em si, e o fazem por considerálo uma via de experimentação. A seguir, apresentamos essas pesquisas.

\subsection{Pesquisas realizadas em grupos de participantes do Pibid}

Nessa categoria constam três dissertações que não têm o Pibid como objeto, mas cujos sujeitos pesquisados são participantes do programa. O fato de o Pibid estar 
presente nessas pesquisas, mesmo de forma coadjuvante - diversamente dos trabalhos de pesquisa reunidos nas demais categorias, em que o programa é o foco , demonstra quão disseminada está essa política nos cursos de licenciatura, ao ponto de suas atividades despertarem interesse por si próprias.

Cozza (2012) oferta uma oficina de formação pedagógica em Modelagem Matemática a quatro supervisores e 19 bolsistas ID e pesquisa se houve mudança de opinião dos participantes sobre o método de ensino e pesquisa da Modelagem. Foram utilizados os seguintes instrumentos: questionários, intervenções pedagógicas e gravação de depoimentos transcritos em forma de diário de classe.

As intervenções consistem em quatro oficinas sobre aplicação da modelagem matemática ofertadas aos participantes do Pibid. Em seguida, eles elaboraram e ofertaram oficinas de Modelagem nas escolas públicas, após as quais se reuniram em um seminário para relatar experiências. Cozza (2012) não justifica de forma suficiente sua escolha do Pibid e erra ao elencar os objetivos do programa. Segundo Cozza, "a intenção do PIBID é unir secretarias de educação e universidades", melhorar o ensino em escolas públicas e promover formação continuada. Nenhum dos três pontos é escopo do programa. Aqui os participantes do Pibid são apenas amostragem e o programa em si não é o objeto da pesquisa.

O trabalho de pesquisa que gerou a dissertação de Köhler (2013) propõe ao subprojeto Pibid Química UFSM a realização de oficinas sobre o assunto "estética capilar e química" nas quatro escolas parceiras do projeto. Em primeiro lugar, licenciandos, supervisores, coordenadora de área e a autora participaram de uma capacitação para preparar a atividade a ser desenvolvida nas escolas; então, houve a aplicação da oficina. O Pibid aqui foi descrito brevemente e serviu apenas como meio de realizar a oficina. O projeto em si não é o objeto do estudo: esse trabalho propõe uma atividade de oficina temática sobre estética capilar para o ensino de Química nas escolas.

Raizer (2013) quer identificar as crenças sobre a língua espanhola e o processo de ensino-aprendizagem de línguas de um grupo de alunos da educação básica que frequenta um curso de espanhol ofertado por alunos do Pibid. O projeto 
Pibid foi escolhido apenas por ser um mediador já estabelecido entre universidade e escola por meio da qual a pesquisadora se inseriu no ambiente escolar.

Nos estudos acima, o Pibid é ora a ferramenta que torna viáveis as propostas experimentais dos pesquisadores, pois a dinâmica do programa se fundamenta no desenvolvimento de atividades inovadoras (COZZA, 2012; KÖHLER, 2013); ora o ambiente mediador entre a academia e a escola, que possibilitou a inserção da investigadora no ambiente da educação básica (RAIZER, 2013). A promoção de atividades inovadoras e a aproximação entre universidade e escola são objetivos do Pibid. Portanto, podemos considerar a existência dessas pesquisas como um índice de que a proposta do Pibid tem um rebatimento para além dos limites dos projetos implementados.

\subsection{Pibid como política pública}

Esta seção traz um artigo que aborda o Pibid como uma política pública, ou seja, como uma iniciativa social - governamental ou privada - que visa a resolver problemas sociais. O foco é a interação entre níveis de ensino e sua influência na formação de professores, com rebatimento na valorização da profissão docente.

Ristoff e Bianchetti (2012) abordam a relação conflituosa entre pós-graduação (PG) e educação básica (EB) no Brasil, com o objetivo de evidenciar que as interlocuções entre esses dois níveis de formação garantem a manutenção de um suposto apartheid socioeducacional, iniciado no período colonial. A hipótese dos autores é a de que, no Brasil, as políticas de educação são mais eficientes no suprimento das necessidades educacionais dos grupos situados no topo da pirâmide social e menos eficazes no atendimento dos situados em estamentos médios. Elas parecem, ainda, menos voltadas para a grande população componente da base da pirâmide.

O argumento é fundamentado na história da formação de professores, na qual se pode notar um recorrente dualismo ${ }^{4}$ presente em ações governamentais que visavam a incluir nos níveis mais avançados de qualificação os poucos privilegiados e

\footnotetext{
${ }^{4}$ Sobre o dualismo estrutural nas políticas educacionais brasileiras, conferir o artigo de Teixeira (1962).
} 
deixar à parte a maioria da população. Os autores apontam seis "dualidades estruturais" fundantes das concepções de sistemas educacionais no Brasil.

Após a redemocratização, ocorrida nos anos 1980, nota-se um esforço no sentido de criar um sistema nacional de educação - entendido como uma relação orgânica entre os níveis de ensino (pré-escola, educação básica, educação superior e pós-graduação). Mesmo iniciativas sistematizadoras dessa natureza demonstram priorizar o topo da pirâmide, como na criação da Capes em 1950. Somente nos anos 2000, com a reestruturação desse órgão, as políticas educacionais demonstram preocupação com os estamentos socioeducacionais inferiores e acenam para uma integração entre EB e PG.

Em primeiro lugar, temos a bifurcação proposta pelos jesuítas de Manuel da Nóbrega no séc. XVI, segundo a qual os melhores alunos das "escolas de ler e escrever" serão destinados ao aprendizado de humanidades, enquanto os não "bons da cabeça" seguem para trabalhos manuais.

A segunda discriminação estrutural se refere ao "contorcionismo" verbal de legisladores no séc. XVII e sua tentativa de perpetuar a lógica de que filhos da elite devem estudar mais e os dos pobres, menos - pela natureza mesma de como a sociedade se estrutura. $O$ terceiro dualismo reporta às formulações da administração científica propostas por F. Taylor (1856-1915), que dividem o trabalho entre planejamento - destinado a especialistas - e execução - manual e menos dependente de esforço intelectual.

Com a chegada da família real portuguesa ao Brasil em 1808 e a elevação da colônia a reino unido, implantaram-se os primeiros cursos superiores, e teve lugar a quarta dualidade - priorização da educação superior para manter a corte provida por profissionais qualificados, acompanhada da criação de classes com centenas de alunos em regime de monitoria entre colegas de série para a educação básica.

A quinta dualidade se refere à "exclusão includente", manifestada na universalização do acesso à educação, mas com redução da qualidade. Dentro do movimento denominado pelos autores de sexta dualidade, a criação da Capes, em 1951, reforça a formação de professores para a educação superior; incentivo não acompanhado de uma iniciativa análoga para qualificar a educação básica. Nesse 
momento, gestores como Anísio Teixeira (1900-1971) acreditam que o investimento em qualidade na pós-graduação alavancaria, por reação em cadeia, a qualidade nos demais níveis de ensino. Contudo, os beneficiados pela iniciativa permanecem os grupos minoritários de elite.

Em seguida, Ristoff e Bianchetti (2012) relatam a criação do primeiro curso de pós-graduação stricto sensu em Educação na PUC-RIO e da Associação Nacional de Pesquisa e Pós-Graduação em Educação (Anped), em 1978; segundo eles, uma iniciativa que garantia quadros para avaliação ad hoc da Capes. O nome da associação - que mencionava originalmente apenas "pós-graduação", recebendo o complemento "pesquisa" quatro anos depois, mas mantendo-os separados - seria um indício da dualidade apresentada acima: a pós-graduação está voltada para a formação de pesquisadores e quadros para a educação superior; quando se volta para a educação básica, toma por "objeto" de pesquisa a escola.

Para tentar quebrar a mencionada lógica de foco na formação para nível superior e alavancar a formação de professores para a educação básica, as atribuições da Capes foram expandidas em 2008. A partir de então, a fundação passou a fomentar por meio de programas a formação docente para a educação básica, inclusive na modalidade a distância - por meio da Universidade Aberta do Brasil (UAB). Essa nova priorização encontraria resistência em setores acadêmicos e no governo, que chegaram a apelidar as novas atribuições de "Capes do B", motivados, entre outros argumentos, pelo receio de que os recursos destinados à pós-graduação fossem repartidos com a educação básica - temor não concretizado, pois o orçamento do órgão mais que duplicou no ano de 2009 , atingindo $R \$ 1,3$ bilhão ${ }^{5}$.

Não houve apenas uma expansão orçamentária, mas uma consolidação de objetivos na forma de propostas apresentadas na Conferência Nacional de Educação Básica (Coneb) de $2008^{6}:$ 1) todas as disciplinas da educação básica teriam professores licenciados para ministrá-las; 2) nenhuma evasão profissional de

\footnotetext{
${ }^{5}$ O orçamento da Capes em 2013 atingiu $\mathrm{R} \$ 4,8$ bilhões. A evolução do orçamento da fundação desde 2004 pode ser encontrada em <http://www.capes.gov.br/images/stories/download/sobre/Orcamento_2004-2013_tabela.pdf >. $<$ http://portal.mec.gov.br/arquivos/conferencia/documentos/doc_final.pdf >.
} 
licenciados poderia ser motivada por falta de valorização do magistério; 3) todos os professores teriam formação prática em sala de aula; 4) todos os licenciados seriam formados em cursos cujos currículos contemplassem especificamente a educação básica; 5 ) todos os níveis de escolaridade estariam envolvidos no esforço comum de melhoria da qualidade da educação; 6) os estudantes da educação básica deveriam apresentar melhorias no rendimento de exames nacionais e de padrão internacional; 7) as escolas deveriam apresentar ambiente propício para desenvolvimento cognitivo e emocional dos estudantes.

Ao analisar os programas gerados a partir da Nova Capes, Ristoff e Bianchetti (2012) apontam o Pibid como o primeiro a abarcar em seu fomento desde a escola até as IES com bolsas para supervisores e professores pesquisadores. No momento inicial do programa, foi patente a dificuldade de as IES dialogarem com os gestores locais de educação quando se multiplicaram os casos de problemas em firmar convênios entre elas e as secretarias de educação, exigência da Capes para garantir interlocução entre os agentes do programa. Contudo, um programa como o Pibid não tem a pretensão - nem a capacidade - de solucionar os inúmeros problemas da educação básica.

Os autores comentam outros programas da DEB. No caso do Programa de Consolidação das Licenciaturas, Prodocência, cujo objetivo era a renovação curricular das licenciaturas, seu tamanho diminuto em relação ao Pibid resulta antes na indução de comportamentos pontuais do que promove grandes transformações em propostas curriculares. Já o Observatório da Educação estimula pesquisas baseadas em dados do Inep. Somam-se aos programas citados o Plano Nacional de Formação de Professores da Educação Básica (Parfor) e a UAB.

Apesar das diversas iniciativas, o número de professores licenciados ainda encontraria dificuldades para aumentar, pois as taxas de matrículas em cursos de licenciatura apresentam quedas anuais, ao contrário dos outros cursos (Inep, 2009). Outro indicador preocupante é a maior média de idade dos licenciandos em relação aos estudantes de bacharelado: $51 \%$ deles estão acima da faixa considerada apropriada, de 19 a 24 anos. Os autores concluem afirmando ser de difícil realização a meta de aumento da taxa de escolaridade proposta pelo Plano Nacional de 
Educação 2011-2020. As diversas iniciativas implementadas apresentam baixa efetividade. Seria necessário, portanto, investir em ações que envolvessem comunidade acadêmica e sociedade no esforço de melhorar, principalmente, a formação em nível médio.

A preocupação dos autores é pertinente e merece mais investigação. Em que medida o modo de ser acadêmico, voltado para a pesquisa, pode influenciar negativamente - o desenvolvimento das licenciaturas e da própria profissão de professor da educação básica? Mais à frente, no capítulo 5 , abordamos a prática da pesquisa realizada no âmbito do Pibid, um programa voltado para a inserção do licenciando na prática profissional. Pontuaremos o risco de projetos Pibid se desviarem de seu foco e assumirem caráter de pesquisa acadêmica, corroborando as observações de Ristoff e Bianchetti (2013). 


\section{SUBPROJETO PIBID FÍSICA NA UNB: CONSTRUÇÃO E DESENVOLVIMENTO DE UM MODO DE FORMAR PROFESSORES}

Nos capítulos anteriores, discorremos sobre a história da formação de professores no Brasil, a partir da qual se pode perceber um descaso reiterado por parte dos entes estatais. Além disso, apresentamos o contexto atual das políticas relativas à educação dos docentes, com início na década de 2000 , quando estudos constataram um déficit profundo na quantidade de docentes qualificados adequadamente para atuação na educação básica, sendo a área de Física a principal deficitária. No período citado, foram lançadas políticas objetivando reverter a situação de falta de professores e melhorar ao mesmo tempo a qualidade da formação. Entre os programas implementados está o Pibid, com sua proposta de ampliar o contato do estudante de licenciatura com a sala de aula.

Vimos também que muitos trabalhos acadêmicos vêm tematizando o Pibid desde 2009, ano inicial de atividades do programa. Contudo, eles priorizam a análise de discursos dos participantes sobre o Pibid. Para a maior parcela dos trabalhos levantados, o interesse reside nas opiniões dos envolvidos em relação à sua experiência formativa. Predominam metodologias qualitativas, com uso de entrevistas e questionários, sendo a análise de discurso o instrumento predominante na análise dos dados. Nenhum trabalho investigou as atividades em si, sua construção, implementação e aderência aos propósitos do programa declarados pela instituição gestora, a Capes.

Com base nas informações coletadas, apresentamos nossa proposta de pesquisa: analisar as atividades realizadas pelo subprojeto Pibid Física UnB e verificar em que medida elas guardam coerência com as expectativas da política pública Pibid, expressas nos documentos regulatórios. Para tanto, propusemos a análise do relatório de atividades do subprojeto, relativo ao ano de 2014 , ano em que o Pibid foi "reiniciado", tendo um novo regulamento e um desenho diverso das edições anteriores.

Este capítulo traz a análise do subprojeto Pibid Física UnB, iniciando pelo subprojeto submetido à seleção da Capes em 2013; em seguida, voltamos o olhar 
para o relatório de atividades de 2014. Nossa análise buscará nos documentos: objetivos, metodologias, ações, forma de relação entre universidade e escola e resultados esperados. Ao final desta seção, será possível discutir a aderência do subprojeto Pibid Física às intenções manifestas da política pública em questão, a partir de nosso olhar de membro da equipe técnica da Capes.

\subsection{O subprojeto Pibid Física da Universidade de Brasília}

Apresentamos a seguir o subprojeto Pibid Física UnB, objeto da pesquisa. Inicialmente fazemos uma observação quanto ao material analisado. Trabalhamos com dois documentos:

a. Proposta na íntegra. Fornecida adicionalmente pela coordenação de área, traz a totalidade da proposição. Trata-se de um documento mais abrangente que o integrante do projeto institucional inscrito e dispõe de informações de grande valor para a compreensão do projeto para além do aspecto institucional, o que é nosso objetivo. Nela, estão detalhadas as sete especificações demandadas pela Portaria Capes n. 96/2013 em seus art. 6o e 8ำ (CAPES, 2013ํ): o contexto educacional da região em que ocorrerão as atividades; escolas da rede pública nas quais se pretende inserir os alunos; ações/estratégias para inserção dos bolsistas nas escolas; estratégia para aperfeiçoamento da língua portuguesa; formas de seleção, acompanhamento e avaliação de bolsistas; sistemática de registro e acompanhamento de egressos; atividades de socialização dos resultados; resultados de projetos anteriores. Ao final, o documento traz a proposta inscrita na seleção da Capes.

b. Subprojeto de Física apresentado à seleção da Capes. Extraído do sistema de inscrição, contém apenas informações técnicas sucintas, devido à restrição no número de caracteres imposta pelo edital. São elas: identificação (modalidade - presencial ou a distância; número de bolsas solicitado; níveis de atuação - fundamental, médio etc.; modalidade de 
ensino - educação regular, EJA etc.; município); dados dos coordenadores de área; ações, com título e detalhamento.

Procederemos à análise da proposta na íntegra (Documento "a."), pois ela traz um detalhamento mais rico do que a Capes solicita de um subprojeto. Na verdade, a proposição da coordenação de área vai além e contempla informações demandadas de um projeto institucional (CAPES, 2013b, p. 4-5). Esse rigor nos parece positivo, na medida em que indica a preocupação da coordenação de área em desenvolver uma proposta sólida, indo além da descrição de um conjunto de atividades. Notamos que o Documento "a." possui nove ações propostas, três a mais que o descrito no Documento "b.", e essa é a única diferença significativa entre os textos. Abordaremos esse ponto divergente ao final da seção.

\subsubsection{Contextos educacional da região onde o projeto será desenvolvido}

O subprojeto Pibid Física da UnB aponta três regiões administrativas (RA) do Distrito Federal (DF) como áreas de atuação: Ceilândia (RA IX), Plano Piloto, ou Brasília (RA I), e Taguatinga (RA III). Como justificativa para a escolha, o subprojeto indica Ceilândia e Taguatinga como as regiões que apresentam "grande número de escolas com baixo IDEB" (UNB, 2013) e como locais de residência de muitos bolsistas, o que facilita o trânsito para as escolas parceiras.

Pensar na distribuição de escolas levando em consideração o deslocamento dos estudantes, e não apenas o resultado do Ideb, é uma maneira que nos parece apropriada de estruturar o projeto, pois evita dispersão de esforços da equipe para realizar as atividades, o que pode resultar em um número reduzido de evasões do subprojeto. Conforme veremos na seção 4.1.2, dentre as escolas parceiras está uma unidade localizada na cidade do Cruzeiro (RA XI). O subprojeto não diferenciou Cruzeiro de Brasília; mas faremos essa distinção, em observação à divisão administrativa oficial, por um lado, e devido ao fato de as duas cidades apresentarem indicadores sociais diversos o suficiente para demandar ações educacionais específicas. 
Sobre a geografia política do Distrito Federal, cabe uma observação. No DF, não existem municípios, mas regiões administrativas. Cada RA possui administração local própria, cujos representantes são indicados pelo governador, sem eleições ou consultas populares. De fato, as RA, ou cidades-satélites, como são popularmente conhecidas, assemelham-se a cidades autônomas, pois seus espaços geográficos são delimitados, apresentam aspectos culturais próprios e indicadores sociais bastante distintos. Apresentamos a seguir alguns dados adicionais sobre as localidades abrangidas pelo subprojeto.

Inaugurada em 1960 para abrigar a nova capital federal, Brasília continua sendo o centro financeiro e político do Distrito Federal: a cidade concentra $48 \%$ das ocupações existentes no DF e recebe $64 \%$ dos que trabalham fora de sua RA (CODEPLAN, 2013a). Sua população estimada é de 221 mil habitantes, a maior parte é do sexo feminino (53\%), tem idade entre 15 e 59 anos (51\%), se declara branca (65\%); nasceu em outra unidade da federação ou no exterior (65\%) e possui nível superior (53\%). Chama a atenção o fato de $77 \%$ dos residentes na cidade não estudarem. Analfabetos não somam nem sequer 0,5\% do total. Em Brasília, 89\% da população trabalha e $97 \%$ estuda na própria região. Isso indica quão pouco os habitantes de Brasília circulam pelo restante do território. Quase a totalidade dos domicílios recebe água pela rede geral, possui esgotamento sanitário e rede elétrica, além de contar com serviço de limpeza urbana. O rendimento domiciliar médio é de $R \$ 12.742,21$, ou 17,6 salários mínimos (SM), e a renda per capita é de $R \$ 5.188,84$ (7,17 SM) (CODEPLAN, 2014b).

Desmembrada de Brasília em 1989, a RA Cruzeiro possui 32 mil habitantes. Parte do projeto inicial de Brasília, e localizada imediatamente ao lado do Plano Piloto, a composição atual de sua população tem predominância de mulheres (54\%), pessoas de 15 a 59 anos (69\%), pardos (51\%) e nascidos em outro estado ou país (55\%). No quesito escolaridade, 32\% dos residentes possuem nível superior completo, 27\% completaram o ensino secundário, $15 \%$ não concluíram a instrução fundamental e $74 \%$ não estudam. Todos os domicílios da cidade recebem água da rede geral, possuem esgotamento sanitário, rede elétrica e serviço de limpeza urbana. Quase a totalidade dos residentes trabalha em outra RA (82\%; 69\% apenas em 
Brasília), e $56 \%$ dos que estudam o fazem em Brasília, enquanto $38 \%$ permanecem na cidade. A renda domiciliar média é de $\mathrm{R} \$ 8.072,78$ mil, ou 11,91 SM, e a renda per capita é de $R \$ 2,677,70$ mil (3,95 SM) (CODEPLAN, 2014a).

Com 450 mil habitantes, Ceilândia é a mais populosa cidade do Distrito Federal. Distante $26 \mathrm{~km}$ de Brasília, a localidade teve origem nos anos $1970 \mathrm{com} o$ assentamento de cerca de 80 mil moradores removidos de moradias irregulares por ação de um programa público. Os residentes são predominantemente mulheres (51\%), têm de 15 a 59 anos (63\%), são pardos (53\%) e nascidos no DF (52\%). Com relação ao grau de instrução, 38\% completaram apenas o nível fundamental, $22 \%$ concluíram o nível secundário, $5 \%$ têm nível superior e $71 \%$ não estudam. Destacamos o alto percentual de analfabetos, $3,41 \%$ da população - o mais alto entre as cidades abrangidas pelo subprojeto Pibid Física UnB.

Limpeza urbana, água da rede geral e energia elétrica estão em praticamente todas as residências de Ceilândia, diferentemente do esgotamento sanitário, o qual se encontra em não mais que $84 \%$ delas, pois $7 \%$ dos lares contam com fossas rudimentares e $9 \%$ usam fossa séptica. Dentre os economicamente ativos, $49 \%$ trabalham em outra RA (majoritariamente em Brasília, 28\%; e em Taguatinga, 11\%). A renda média domiciliar é de $R \$ 2,5$ mil (3,5 SM), e a renda per capita é de $R \$$ 718,40 , pouco superior a um salário mínimo da época (CODEPLAN, 2013b). Os números apresentados acima permitem afirmar que Ceilândia possui os piores indicadores sociais dentre as cidades abrangidas pelo subprojeto, mas é a mais "brasiliense", contando com o maior percentual de nascidos no DF. Também é a região em que mais pessoas afirmam estudar.

Taguatinga possui 214 mil habitantes, número que a posiciona em quarto lugar em número de habitantes no DF. Localizada a $22 \mathrm{~km}$ de Brasília, a cidade possui uma população formada, em sua parcela majoritária, por mulheres (54\%), pessoas de 15 a 59 anos (63\%), brancos (50\%) e imigrantes (52\%). O nível de escolaridade predominante é o fundamental incompleto (25\%), seguido de médio completo (24\%) e superior (18\%). Analfabetos somam 1,5\%, e 73\% dos habitantes não estudam. Fornecimentos de água e energia elétrica, bem como limpeza urbana e esgotamento, estão presentes em quase todas as residências. 
Os trabalhadores, de Taguatinga, em sua maioria, exercem suas atividades na própria cidade (44\%), mas $31 \%$ deles têm sua ocupação em Brasília. Também se concentra na cidade a população de estudantes (84\%), e apenas $7 \%$ frequentam aulas em Brasília. A renda domiciliar média é de $\mathrm{R} \$ 5.138,58$ (7,58 SM), e a renda per capita é de $\mathrm{R} \$ 1.639,04$ (2,42 SM) (CODEPLAN, 2013c).

A Figura 10 apresenta a distribuição das escolas participantes do subprojeto Pibid Física UnB pelo território do Distrito Federal:

Figura 10 - Localização das escolas participantes do subprojeto Pibid Física UnB

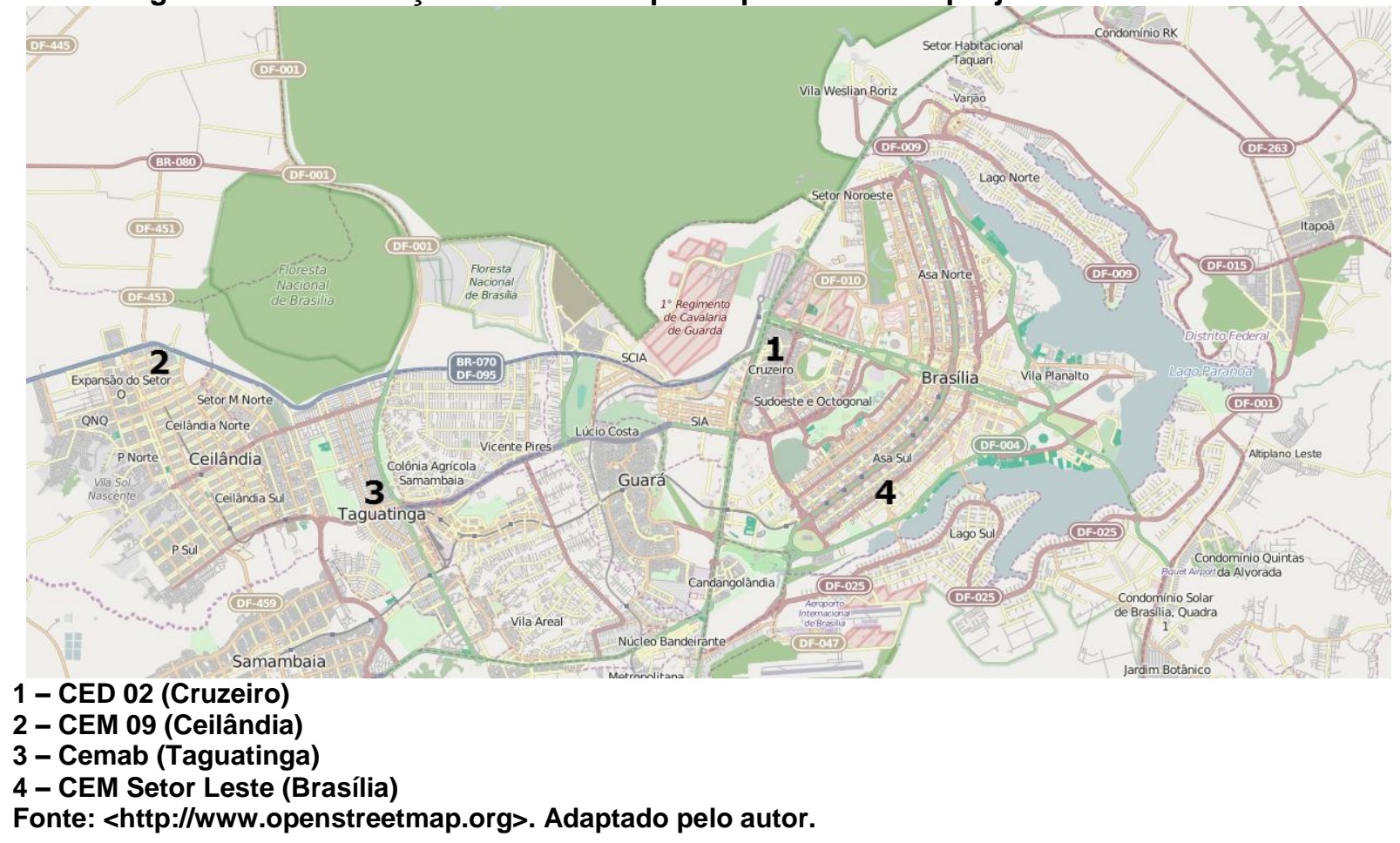

Nossa análise é a de que o contexto apresentado pela proposta é demasiado sucinto. Por um lado, é satisfatória a justificativa para a escolha de Taguatinga e Ceilândia, fundamentada em facilitar o deslocamento dos licenciandos. Esse procedimento busca evitar desistências relacionadas à dificuldade em conciliar os períodos dedicados ao subprojeto e à licenciatura. Contudo, dispor de alguma informação socioeconômica, política ou geográfica sobre as localidades pode potencializar a experiência no programa, na medida em que isso possibilita a construção de atividades ainda mais coerentes com realidades locais. 
Por exemplo, a proposta não diferencia Brasília e Cruzeiro, RA distintas, e isso pode impactar o desenvolvimento do projeto. Por exemplo, ações propostas devem levar em consideração que os alunos de educação básica do Cruzeiro podem, na verdade, não compartilhar da realidade local por não residirem na cidade - situação talvez oposta à de Brasília. Naturalmente, se trata de uma possibilidade, uma vez que os dados educacionais sobre as RA apresentados em nossa pesquisa não estão desagregados por nível de ensino (básico, médio e superior) nem por esfera administrativa (privada, distrital e federal). Isso permitiria diferenciar com mais precisão as realidades sociais das cidades, mas esse não é um objetivo de nosso estudo.

\subsubsection{Escolas da rede pública de ensino onde se pretende inserir os alunos}

Quatro escolas foram indicadas, uma em cada RA. Existe a possibilidade de alterar a relação de escolas parceiras a qualquer tempo, mediante notificação à Capes e declaração no relatório de atividades anual do projeto institucional. Portanto, as escolas que iniciam um projeto Pibid podem não chegar ao final do ciclo de quatro anos e outras podem iniciá-lo próximo ao fim da vigência. Na seção 4.1.1, vimos que um dos critérios de seleção das escolas foi o ldeb; contudo, no projeto não existe referência ao índice de cada escola, de modo que não é possível avaliar se foram escolhidas pelo critério de proximidade dos locais de residência dos licenciandos ou pelo índice. Esse dado tampouco consta do projeto institucional, pois não há campo para seu preenchimento no sistema da Capes. As unidades de ensino indicadas são:
a. Centro Educacional 02 do Cruzeiro (CED 02);
b. Centro Educacional 09 de Ceilândia (CED 09);
c. Centro de Ensino Médio Ave Branca (Cemab, em Taguatinga).
d. Centro de Ensino Médio Setor Leste (Brasília) 


\subsubsection{Ações/estratégias para inserção dos bolsistas nas escolas}

Esta seção se inicia com a apresentação de dois objetivos norteadores do subprojeto Pibid de Física:

a. Proporcionar aos futuros professores, atuais licenciandos de Física do Instituto de Física da UnB a participação em Ações, Experiências Metodológicas e Práticas Docentes Inovadoras articuladas com a realidade local da escola;

b. Promover a articulação entre a licenciatura em Física da UnB e a Rede de Educação Básica do Distrito Federal. (UNB, 2013).

Notamos que os objetivos do subprojeto têm redação bastante semelhante à dos objetivos III e IV do programa definidos pela Capes (2013a):

III - elevar a qualidade da formação inicial de professores nos cursos de licenciatura, promovendo a integração entre educação superior e educação básica;

IV - inserir os licenciandos no cotidiano de escolas da rede pública de educação, proporcionando-Ihes oportunidades de criação e participação em experiência;

Avaliamos que o subprojeto deveria apresentar objetivos mais próximos de sua proposta de trabalho nas escolas, evitando reiterar o conteúdo da Capes. Não sugerimos desviar a proposta das metas estabelecidas pelo órgão de fomento, mas acreditamos que é possível construir um texto de maior coerência com as atividades. Uma possibilidade é revisar as ações e, a partir delas, redigir um objetivo para o ano seguinte. Esse exercício pode ser feito coletivamente pelos participantes ao final de cada período letivo, após a avaliação dos resultados.

Em seguida, o documento expressa que a metodologia adotada se configura como "dialógica e cooperativa", "centrada na transformação da realidade escolar" e fundamentada no conceito de "aprendizagem colaborativa". A ideia associada ao conceito é a de "permitir aos professores de Física desenvolverem ações colaborativas" em um "processo de formação continuada permanente e dinâmico", no qual cada participante seja "agente e protagonista de sua formação", auxiliando na formação do coletivo do projeto (UNB, 2013).

Não consideramos profícuo para os objetivos desta pesquisa discutir a pertinência do uso do termo aprendizagem colaborativa pela proposta do subprojeto, pois, como aponta Dillenbourg (1999), não existe sinal de consenso acadêmico em 
torno de uma conceituação. A definição ampla, segundo a qual aprendizagem colaborativa é a "situação na qual duas ou mais pessoas aprendem ou tentam aprender algo junto" (grifo do autor) é considerada insatisfatória pelo autor, pois "dois ou mais", "aprender" e "junto" comportam interpretações diversas, de modo que o próprio pesquisador se abstém de fechar uma acepção, em prol da compreensão de natureza multidisciplinar (DILLENBOURG, 1999). Acompanhamos o raciocínio do pesquisador e nos limitamos a sugerir que o subprojeto indique uma referência conceitual de aprendizagem colaborativa para situar sua proposta.

Ao mencionar "professores de Física", o texto parece referir-se tanto aos supervisores quanto às coordenadoras de área. Incluir todos os docentes na categoria de aprendizes é uma iniciativa louvável, pois demonstra o intento de evitar a concepção "colonizadora" da universidade sobre a escola que caracteriza projetos semelhantes de aproximação entre as duas instituições.

Nessa concepção, a universidade, centro produtor do saber, enquadra a escola como objeto de estudos ou campo de experiências, e provê respostas para os problemas identificados e estudados. Não corroboramos essa ideia. Justamente por desmerecer a capacidade de a comunidade escolar entender a si própria, essa abordagem promove uma construção de conhecimento de valor mais restrito. $O$ planejamento do trabalho é subdividido em 4 etapas:

Etapa 1: Caracterização da Escola e levantamento de indicadores de rendimento escolar e institucional (Infraestrutura física, pessoal, n. de alunos, professores, funcionários, laboratórios, sistema de avaliação das disciplinas, Censo: ENEM, IDEB, SAEB, Mapeamento das expectativas dos alunos etc.). Mapeamento e apresentação dos resultados junto à comunidade escolar.

Etapa 2: Definição de Metas junto à comunidade escolar a serem alcançadas durante o período de execução do projeto; Definição, planejamento e agendamento da inserção dos Licenciandos nas atividades de ensinoaprendizagem da Escola.

Etapa 3: Ação em Sala de aula; Recuperação e Reativação dos Laboratórios de Física; Planejamento e desenvolvimento de atividades didáticopedagógicas baseadas em: experimentos, resolução de problemas, tecnologias da Informação e comunicação (TIC), temas socioambientais, divulgação científica e pedagogia de projetos. Produção cooperativa de Material Didático Instrucional (MDI).

Etapa 4: Participação em Encontros de Avaliação e Formação de toda a Equipe do Projeto. (UNB, 2013).

O roteiro apresentado segue uma lógica linear, indo da aproximação do tema à divulgação de resultados: coleta de dados sobre a escola e sobre os alunos - 
incluindo posterior apresentação dos dados levantados; estabelecimento de metas de trabalho em conjunto com a comunidade escolar; execução de atividades programadas; e exposição das realizações. $\mathrm{Na}$ fase inicial, de levantamento de informações, chama a atenção o "mapeamento das expectativas dos alunos". Essa ação indica que o subprojeto pretende levar em consideração os discursos daqueles que serão mais impactados pelo projeto. A etapa seguinte parece confirmar a intenção de realizar um trabalho conjunto, pois as metas a serem estabelecidas serão construídas coletivamente.

$\mathrm{Na}$ terceira fase, se concentram as atividades de aprendizado pedagógico. Primeiramente, a proposta declara a intenção de inserir os licenciandos em sala de aula, o que não está impedido pelo regulamento do Pibid. O programa veta apenas a regência de classe pelo licenciando. Estão programadas intervenções na estrutura dos laboratórios, para viabilizar as atividades práticas, ação também permitida, com a ressalva no art. 25, IX, de que se evitem obras civis (CAPES, 2013a).

Segundo Borges (2002), a falta de condições para o ensino experimental de Ciências em escolas públicas resulta em muitos casos de sua pouca utilização pelos professores, de modo que os equipamentos ficam devolutos. Nesse sentido, a iniciativa está justificada. $O$ desafio é evitar incorrer em questões administrativas relacionadas ao emprego dos recursos destinados ao subprojeto.

As atividades propostas se baseiam em práticas experimentais, solução de problemas e uso de tecnologias; temáticas de cunho socioambiental farão parte do repertório, o qual inclui ainda divulgação científica e pedagogia de projetos. Existe a previsão de construir "material didático instrucional" de forma "cooperativa". Novamente o projeto contempla as expectativas do programa, pois a produção de material está sugerida no documento "Manual de Orientações para Execução de Despesas do Pibid - Elaboração do Plano de Trabalho" (CAPES, 2014a). Adiante consta a previsão de que os participantes deverão expor suas realizações em eventos de avaliação, observando mais uma vez as designações do programa (CAPES, 2013a).

Podemos afirmar que as etapas do subprojeto contemplam as dimensões de formação docente demandadas pela Capes em seus regulamentos. Essa atenção aos 
aspectos regulatórios evita problemas de ordens tanto pedagógica quanto administrativa, cujas consequências poderiam trazer prejuízo ao desenvolvimento das atividades.

Uma das preocupações manifestas da Capes está relacionada à capacidade de expressão dos participantes em língua portuguesa (CAPES, 2013a). Assim, a quarta seção da proposta apresenta seis ações para reforçar o domínio da língua: leitura crítica de artigos da área de Ensino de Ciências/Física; apresentação de seminários sobre os artigos; produção de material didático; produção de relatórios das atividades realizadas; e escrita de trabalhos para eventos acadêmicos (UNB, 2013).

Poderiam ser excluídas dessa lista as produções de material didático e de relatórios, pois se trata de atividades de cunho experimental, no primeiro caso, e, no segundo, de um dever dos participantes. Sem dúvidas a produção de material pode incluir um roteiro para registro e uso posterior, e relatar as atividades demanda algum engajamento expressivo. Contudo, não sendo o objetivo de nenhuma das duas ações melhorar o uso do idioma, elas podem ser excluídas desta seção sem prejuízos à proposta. Leitura de artigos, seminários e redação de trabalhos para eventos são momentos propícios para desenvolver habilidades expressivas e prevê-los demonstra a preocupação do subprojeto em trabalhar essas competências.

No tópico seguinte, são apresentadas as formas de seleção, acompanhamento e avaliação dos bolsistas de iniciação à docência e de supervisão. Dos primeiros, é exigido: ser aluno regular do curso de licenciatura em Física da UnB; dedicar o mínimo de 15 horas semanais ao projeto; apresentar carta de intenções; possuir coeficiente de rendimento acadêmico mínimo de 3,0. O professor interessado em assumir a supervisão no subprojeto precisa: ser servidor efetivo na Secretaria de Educação do Distrito Federal; ser regente de turma; ter disponibilidade de 15 horas semanais para o projeto; ter licenciatura plena em sua área de atuação. 0 acompanhamento e a avaliação de ambos os agentes serão realizados em reuniões mensais e por meio de relatórios bimestrais.

Esses requisitos têm a intenção de suplementar o regulamento do Pibid (CAPES 2013a, mas trazem as mesmas disposições. Duas exigências são de fato específicas do subprojeto: apenas no caso dos licenciandos é necessário um texto de 
apresentação; e, para ambos, é necessária uma disponibilidade de 15 horas semanais.

A portaria do Pibid não faz referência a períodos mínimos de dedicação para supervisores e demanda o mínimo de 32 horas mensais de licenciandos. Caso a proposta seja aplicada com rigor, ID e SUP precisarão dispor de 60 horas mensais para o Pibid, ou duas horas diárias, com finais de semana inclusos. Parece uma demanda acima do razoável para docentes e estudantes. Otimizar o uso do tempo com um calendário bem estruturado pode gerar resultados mais proveitosos do que ampliar a exigência de dedicação sem ter condições de assegurá-la.

O instrumento de acompanhamento de egressos proposto na sexta seção é um banco de dados com informações oriundas de questionários e entrevistas a serem aplicados anualmente, com destaque para a atuação profissional na ocasião do levantamento e a opinião sobre a influência do Pibid na prática docente. Já a socialização dos resultados será feita por meio de apresentação de trabalhos acadêmicos em eventos e nos seminários de iniciação à docência do Pibid UnB ou de outras IES.

Montar uma base informacional sobre egressos pode ajudar o projeto em futuras avaliações e tomadas de decisão, pois permite comparações entre participantes ao longo do tempo. Sugerimos a elaboração de uma base para todos os participantes, não apenas para os egressos, de modo a potencializar o autoconhecimento do subprojeto. A promoção do intercâmbio de produção acadêmica sobre as atividades do Pibid deve ser estimulada, com a ressalva de que se trata apenas de uma meta colateral do programa, a qual não deve superar em dedicação o empenho em ações na escola.

No item n. 8 da proposta, uma tabela resume os resultados pregressos do subprojeto Pibid Física UnB, relativos ao período 2011-2012. Não há referência ao ano de 2013, pois ele ainda estava em curso no momento da elaboração do documento, e os relatórios anuais são preparados ao final de cada ano letivo. Conforme o relato, cinco tipos de atividades foram desenvolvidos nas três escolas parceiras. Algumas ações não estão acompanhadas da especificação das escolas onde se realizaram, por haverem sido comuns a todas: estudo dirigido (escola CED 
02 do Cruzeiro); roteiros experimentais; nivelamento de Matemática (escola CEM Paulo Freire); projetos; observação de aulas. Cada uma será analisada a seguir.

O estudo dirigido, realizado na escola CED 02, localizada na RA Cruzeiro, consistiu em produzir material para auxiliar no aprendizado das Leis de Newton (no caso do $1^{\circ}$ ano do Ensino Médio) e de Termodinâmica (para o $2^{\circ}$ ano). A coordenação considera satisfatórios os resultados, pois os licenciandos praticaram o emprego da ferramenta e puderam perceber o nível dos alunos em relação aos conteúdos. Com base nos livros-textos dos alunos, os licenciandos aplicaram roteiros experimentais em oficinas frequentadas voluntariamente pelos estudantes das escolas. $O$ texto registra como resultado o reconhecimento da importância do aprendizado da disciplina Física por parte dos alunos.

$\mathrm{Na}$ escola CEM Paulo Freire (Brasília, RA I), foi realizado um nivelamento de Matemática. Por meio de aulas de duas horas acompanhadas por uma dupla de licenciandos, foram trabalhados conteúdos propostos pelo supervisor, o que implicou aumento de interesse dos alunos pelas aulas, pois quem apresentava déficit nos conteúdos passou a resolver problemas.

Em seguida, a proposta detalha quatro "projetos", como são chamadas as atividades temáticas sobre questões cotidianas. No CED 02, o projeto "Meu primeiro carro" usou o conteúdo curricular da disciplina para discutir como analisar detalhes de um veículo, como potência e segurança. Outro projeto desenvolvido na mesma escola foi "Física ajudando em casa", sobre a parte elétrica de uma residência.

$\mathrm{Na}$ escola CEAN (Brasília) foi realizada uma ação de arborização para amenizar a temperatura e elevar a umidade do ar, resultando na preparação de um viveiro de mudas. A redução de temperatura foi alvo de outra ação, não associada a uma escola, de criação de um painel de isolamento térmico a partir da reutilização de embalagens do tipo longa-vida.

Finalizando o relato do subprojeto 2011-2012, encontra-se registrada a atividade de observação, na qual os licenciandos, durante todo 0 ano letivo, assistiram às aulas regidas pelos supervisores. Aqui identificamos uma semelhança com a disciplina de estágio curricular, sem o componente da regência de classe. Uma vez que o Pibid preconiza a realização de atividades de cunho inovador (CAPES, 
2013a), é preciso atenção do subprojeto para não incorrer na confusão entre Pibid e estágio, com prejuízo para o potencial do subprojeto. O item seguinte da proposta, que a encerra, contém o subprojeto Pibid Física UnB redigido no formato do sistema de cadastro de propostas da Capes (Sicapes). Na próxima seção, procederemos à sua análise.

\subsubsection{O subprojeto Pibid Física UnB apresentado à seleção da Capes}

$\mathrm{Na}$ seção 4.1, ao apresentar a proposta do subprojeto Pibid Física UnB, fizemos a ressalva de que o material usado na pesquisa se tratava de um documento de maior extensão e com mais detalhamento do que o texto submetido à apreciação da Capes. Esse documento, inscrito na seleção relativa ao edital Capes n. 61/2013 e contido no final da proposta fornecida pela coordenação de área, será o objeto de análise da seção atual.

Lembramos que o formato é padronizado e contém as seguintes seções: identificação (modalidade - presencial ou a distância; número de bolsas solicitado; níveis de atuação - fundamental, médio etc.; modalidade de ensino - educação regular, EJA etc.; município); dados dos coordenadores de área; e ações, com título e detalhamento. Nosso primeiro passo será sumarizar as informações de identificação e dados dos coordenadores, para, no momento subsequente, analisar as atividades propostas. A presente seção fornece o insumo restante para a compreensão das intenções pedagógicas do subprojeto Pibid de Física da UnB e encerra a primeira parte do capítulo.

No Sicapes, os projetos institucionais e subprojetos recebem uma denominação automática. No caso dos subprojetos, o formato é "Pibid ano do edital de seleção - sigla da IES / área da licenciatura / campus do subprojeto". Portanto, a denominação oficial da propositura analisada é "Pibid 2013 - UnB / Física / Campus Darcy Ribeiro". Continuaremos a chamá-lo apenas "subprojeto Pibid Física UnB" para evitar confusão entre os termos já adotados. Conforme a inscrição, o subprojeto atua na modalidade presencial, com 21 bolsistas de iniciação à docência, quatro supervisores e dois coordenadores de área, os quais apresentaremos no próximo 
parágrafo. Os níveis de atuação serão os ensinos Fundamental e Médio, nas modalidades de ensino educação regular e Educação de Jovens e Adultos (EJA), na cidade de Brasília, DF.

São indicadas duas coordenadoras de área, ambas com o perfil solicitado conforme art. 34 (CAPES, 2013a): são formadas na área do subprojeto; pertencem ao quadro permanente da IES; estão em efetivo exercício e possuem mais de três anos de experiência como docente de educação superior; ministram disciplina na mesma licenciatura do subprojeto; possuem experiência na formação de professores; e não ocupam altos cargos administrativos, como os de reitor ou pró-reitor. São, portanto, elegíveis para a função. Uma delas já coordenava a edição anterior do subprojeto, encerrada em 2013 como decorrência da reestruturação do Pibid.

Serão quatro as escolas parceiras do subprojeto, localizadas em cidades distintas: CED 02 (Cruzeiro), CED 09 (Ceilândia), Cemab (Taguatinga) e Setor Leste (Brasília). Não foi destinado espaço para mais detalhamento sobre as unidades de ensino no Sicapes.

O trecho posterior apresenta o resumo das nove ações propostas pelo subprojeto no item 9.5. As ações foram expostas de forma sucinta, como decorrência do espaço destinado pelo Sicapes a seu detalhamento, limitado a 500 caracteres. São elas:

1. Caracterização da Escola no que se refere à Infraestrutura física, pessoal, n. de alunos, professores, funcionários, laboratórios;

2. Realização de um levantamento dos materiais didáticos pedagógicos disponíveis no estabelecimento de ensino;

3. Realização de um levantamento, mapeamento e análise dos indicadores de rendimento escolar da disciplina de Física no âmbito da escola;

4. Realização de um levantamento, mapeamento e análise dos indicadores de rendimento da escola nos exames oficiais de avaliação (local e nacional);

5. Reativação dos Laboratórios de Física;

6. Concepção, Desenvolvimento e Produção de Materiais Didáticos para uso nas aulas de Física das escolas parceiras. Esses materiais estarão baseados nas seguintes estratégias teórico-metodológicas: Experimentação, Resolução de Problemas, Tecnologias da Informação e Comunicação (TIC), Temas socioambientais, Divulgação Científica e Pedagogia de Projetos;

7. Planejamento e aplicação Material Didático Instrucional elaborado em etapa anterior;

8. Inserção dos Licenciandos na sala de aula em efetivas ações de iniciação à docência; 
9. Elaboração de relatórios e trabalhos científicos para eventos da área com os resultados obtidos ao longo das etapas anteriores. (PROPOSTA, 2013).

Ao cotejar as ações da proposta detalhada, apresentadas acima, com o espelho da inscrição do subprojeto no Sicapes, notamos que o subprojeto inscrito possui seis ações, três a menos que as descritas na versão ampliada. O trecho posterior apresenta o resumo das seis ações propostas pelo subprojeto: caracterização das escolas; indicadores de rendimento escolar e institucional; produção de material didático; planejamento e desenvolvimento de atividades didático-pedagógicas; formação de grupo permanente de trabalho; apresentação dos resultados (SUBPROJETO, 2013, item 8.3). O conteúdo sofreu apenas uma alteração de destaque: a exclusão da atividade n. 5 (reativação de laboratórios).

\subsubsection{Notas analíticas sobre a proposta do subprojeto Pibid Física UnB}

Podemos afirmar que a proposta do subprojeto Pibid Física da UnB apresenta objetivos coerentes com as expectativas da Capes, notadamente no tocante à inserção dos licenciandos no cotidiano escolar. Notamos que, para além dos objetivos declarados, existe na linguagem do projeto a preocupação de proporcionar a presença dos licenciandos nas unidades de ensino. Contudo, a ênfase recai sobre a sala de aula, o que pode limitar as possibilidades de ações inovadoras.

A inovação na escola esperada no Pibid não significa necessariamente abolir o espaço tradicional da sala, mas usar criativamente as demais estruturas. Reiteramos que existe um risco de o subprojeto se confundir com o estágio supervisionado se optar pelo foco na sala de aula, e a equipe precisa se atentar para evitar incorrer nesta prática. $\mathrm{Na}$ apresentação dos resultados de projetos anteriores, entretanto, percebemos a disposição de trabalhar espaços como o viveiro e unir aprendizado de conteúdo, atividade prática e intervenção na escola. Isso indica que as atividades podem ir além do texto da proposta e contemplar os objetivos do Pibid.

Sua metodologia, sucintamente apresentada, revela um anseio por valorizar a figura do supervisor, apontando para uma relação entre universidade e escola que 
busca evitar uma postura colonizadora, segundo a qual a universidade estuda a escola (deficitária, problemática) e leva soluções. Contudo, a proposta deixa de mencionar como os demais integrantes da escola podem ser convidados a participar.

O texto faz referência a uma "comunidade escolar", com a qual serão elaboradas as estratégias para cada ano, mas deixa de detalhar quem compõe essa comunidade: corpo docente, administrativo, funcionários? Os alunos do Ensino Médio, por exemplo, são mencionados apenas na Etapa 1, quando terão registradas suas expectativas.

Durante nossa experiência de visitas a projetos, fomos surpreendidos por algumas iniciativas bem-sucedidas, nas quais os alunos são protagonistas das atividades, atuando em todas as etapas, até mesmo na produção de material didático. Em outras ocasiões, observamos a interação com a sociedade em volta da escola: comerciantes, entidades de terceiro setor e mesmo o Exército estabeleciam parcerias por vezes fundamentais para os projetos. Essa integração com a sociedade poderia ser incluída entre os resultados esperados, para além daqueles mencionados, os quais já estão definidos pelo próprio programa.

\subsection{A proposta implementada: relatório de atividades do subprojeto Pibid Física UnB relativo ao ano de 2014}

Após expormos um histórico da formação de professores no Brasil e discutirmos desdobramentos políticos do tema ocorridos a partir dos anos 2000, com destaque para a Política Nacional de Formação de Profissionais do Magistério da Educação Básica, abordamos especificamente o Programa Institucional de Bolsa de Iniciação à Docência (Pibid), política na qual está inserido o objeto de estudo desta pesquisa, o subprojeto Pibid Física UnB. Na seção 4.1, analisamos a proposta do subprojeto, tanto em sua concepção ampla, construída pelas coordenadoras de área, quanto o documento inscrito na seleção relativa ao edital Pibid 2013 (CAPES, 2013b).

Dedicamos a seção a seguir à análise do relatório de atividades do subprojeto Pibid Física UnB, relativo ao ano de 2014. Nesse documento estão descritas as atividades realizadas pelo subprojeto, as quais serão analisadas em relação à sua 
aderência aos objetivos do Pibid. Lembramos que nosso ponto de vista é o de um integrante da equipe gestora do Pibid na Capes. Dessa forma, queremos pontuar a discussão acadêmica sobre o Pibid para a compreensão do quanto as atividades possuem aderência, entendida como a realização dos objetivos da Capes expressos nos regulamentos da política analisada: Decreto n. 7.219/2010 (BRASIL, 2010), Portaria Capes n. 96/2013 (CAPES, 2013a), Edital Capes n. 61/2013 (CAPES, 2013b), Manual de Orientações para Execução de Despesas do Pibid - Elaboração do Plano de Trabalho (CAPES, 2014).

Uma vez que, a partir da reestruturação do Pibid ocorrida em 2013 (CAPES, 2013a), os projetos Pibid passaram a ter duração de quatro anos, o relatório analisado é classificado como "parcial", pois contém informações relativas apenas ao primeiro ano de realização do subprojeto, 2014.

Precisamos pontuar que a licenciatura em Física da UnB possui subprojeto em atividade no Pibid desde 2009, na primeira edição do programa; e que, em 2012, após aprovação em novo edital (CAPES, 2011a), as atividades foram continuadas. Ao dizer "continuadas", referimo-nos especificamente à execução de um subprojeto na área de Física pela UnB. Fazemos essa restrição devido ao fato de ter havido substituições na coordenação de área desde o início do Pibid na IES e de os coordenadores que assumiram certamente terem impactado o desenvolvimento das atividades. Porém, as propostas não podiam sofrer alterações, pois haviam sido aprovadas por comissões avaliadoras quando do processo seletivo de cada edital. Tal estabilidade das propostas desenvolvidas nos permite afirmar que o subprojeto da licenciatura de Física não é "novo", mas a continuidade de um processo.

O relatório de atividades analisado é dividido em seis seções: 1) dados da equipe, em que estão relacionados coordenadores, supervisores, licenciandos e escolas; 2) atividades desenvolvidas e resultados alcançados; 3) descrição da produção educacional gerada; 4) descrição de impactos das ações/atividades do projeto na formação de professores, na licenciatura, na educação básica, na pósgraduação e nas escolas participantes; 5) dificuldades encontradas e justificativas de atividades não realizadas; 6 ) considerações finais e perspectivas. Esse formato é adaptado de um modelo disponibilizado pela Capes (CAPES, 2012), o qual contém, 
adicionalmente, espaços para inserção de informações relativas ao projeto institucional: dados da IES, do projeto e bens adquiridos.

\subsubsection{Dados da equipe participante e das escolas parceiras}

No item inicial do relatório, o qual apresenta a equipe e as escolas, fazemos dois destaques. O primeiro diz respeito ao número de bolsistas ID por escola. Em 2014, 27 alunos da licenciatura fizeram parte do Pibid, dos quais oito exerceram atividades na escola CED 02 (RA Cruzeiro); destes, três se desligaram do Pibid, sendo cinco o número de ID na unidade de ensino. Todos os cinco ID da CEM 09 (Ceilândia) e da CEMAB (Taguatinga) seguem no Pibid; na CEM Setor Leste (Brasília), foram nove os participantes, dois quais três se desligaram. No subprojeto, cinco ID são do sexo feminino, todas em atividade em dezembro de 2014; dos 22 ID do sexo masculino, 16 permaneceram até o fim do ano.

A quantidade de ID por escola é equilibrada; portanto, não se espera sobrecarga de algum dos supervisores. Todos os seis bolsistas ID desligados estavam vinculados às escolas CED 02 e CEM Setor Leste. Essa rotatividade mereceria um comentário da coordenação, pois ocorreu nas escolas mais próximas da IES, para as quais o acesso seria mais fácil. Dos dez ID atuantes no CEM 09 e no CEMAB, apenas um ingressou antes de junho de 2014.

Entendemos, a partir dessa informação, que as atividades nessas escolas começaram em momento posterior ao das demais, pois o Pibid teve início com o ano letivo da IES, em março de 2014. No relatório, não foi encontrada notificação sobre a diferença de período de ingresso dos ID. Isso deveria ser comentado, para auxiliar o leitor a dimensionar as atividades nessas escolas conforme o tempo de execução do subprojeto.

Destacamos também, nesta primeira parte do relatório, a relação de escolas participantes (Figura 11), que traz resultados de Ideb e Enem, número de alunos de cada unidade e número de alunos da escola envolvidos no projeto. Não há espaço para informação do número de turmas nem das modalidades de ensino 
correspondentes a cada uma. Mesmo não sendo requeridas no modelo de relatório da Capes, tais informações podem ser incluídas pelo subprojeto em documentos futuros.

Figura 11 - Relação de escolas participantes do subprojeto Pibid Física UnB

\begin{tabular}{cccccc}
\hline Escola & Localização & Ideb & Enem (média geral) & Alunos & Alunos no Pibid \\
CED 02 & Cruzeiro & 3,3 & 491,24 & 966 & 225 \\
CEM & Brasília & 3,3 & 518,12 & 1489 & 400 \\
CEM 09 & Ceilândia & 3,3 & 493,45 & 1444 & 225 \\
Cemab & Taguatinga & 3,3 & 513,91 & 2527 & 440 \\
\hline
\end{tabular}

Fonte: UNB, 2014. Adaptado pelo autor.

Conforme o relatório, o Inep não informa resultados de Ideb para o $3^{\circ}$ ano do Ensino Médio por escola, mas apenas a média estadual. Isso foi constatado em pesquisa junto à página de divulgação do ldeb (Disponível em: <http://ideb.inep.gov.br/resultado/>. Uma vez que são conhecidas as disparidades de condições sociais entre as localidades das escolas de um estado, ou mesmo dentro de uma mesma cidade, conhecer apenas a média estadual do Ideb limita a análise do contexto das escolas solicitada pela própria Capes. De todo modo, é possível notar o baixo resultado do Ideb, cuja escala oscila ente 0 e 10: está abaixo da média nacional (3,4 em 2013) e da meta para o DF (3,6 em 2013), mas supera o resultado de 3,1 auferido em 2011 (Figura 12).

Figura 12 - Resultados do Ideb - observado e metas

\begin{tabular}{|c|c|c|c|c|c|}
\hline & \multicolumn{5}{|c|}{ Ideb Observado } \\
\hline Estado & $2005^{\star}$ & $2007^{\star}$ & $2009^{\star}$ & $2011^{\star}$ & $2013^{\star}$ \\
Distrito Federal & 3.0 & 3.2 & 3.2 & 3.1 & 3.3 \\
\hline
\end{tabular}

\begin{tabular}{|c|c|c|c|c|c|c|c|}
\hline \multicolumn{8}{|c|}{ Metas Projetadas } \\
\hline $2007^{\star}$ & $2009 *$ & $2019^{\star}$ & $2013^{\star}$ & $2015^{*}$ & $2017^{*}$ & $2019 *$ & $2021 *$ \\
3.0 & 3.1 & 3.3 & 3.6 & 3.9 & 4.4 & 4.6 & 4.8 \\
\hline
\end{tabular}

Fonte: <http://ideb.inep.gov.br/resultado/>. Adaptado pelo autor. Destaques referem-se aos resultados que alcançaram a meta 


\subsubsection{Atividades desenvolvidas e resultados alcançados}

A segunda seção apresenta o cerne do relatório e da análise desta pesquisa, as ações dos licenciandos durante o ano letivo de 2014. Organizado em formato de tabela, o texto traz objetivo, descrição e resultados de cada atividade, com indicação da escola específica em que foi realizada. Também estão sinalizadas ações das quais participaram todos os integrantes do subprojeto. Ao todo, o relatório apresenta 16 atividades, as quais analisaremos a seguir.

Comuns a todos os licenciandos, foram realizadas as seguintes ações:

a. Caracterização da escola: as primeiras semanas de atividade do subprojeto foram dedicadas ao conhecimento das escolas no tocante à infraestrutura, pessoal, alunos, professores, laboratórios e métodos de avaliação de disciplinas.

b. Observação de professor em aulas com auxílio didático: exercício voltado para a prática docente em sala de aula, como métodos de abordagem de conteúdos, montagem e implementação de planos de aula e uso do tempo. Os licenciandos prestaram auxílio em situações de demonstração de exercícios e experimentos.

c. Reuniões semanais - com o supervisor, na escola, e com as coordenadoras de área, na UnB.

d. Participação no encontro do Pibid UnB: ocorrido em 20/09/2014, é o evento regulamentar de socialização dos resultados entre os subprojetos (CAPES, 2013b). Com o tema "Narrativas", o encontro de 2014 da UnB buscou estimular registros e reflexões dos docentes sobre suas práticas.

e. IX Semana de Física: de 3 a 7 de novembro, durante a Semana Universitária da UnB, os licenciandos participaram de minicursos e palestras, relativos a temas como ensino de Física Moderna, divulgação científica, ensino em classes hospitalares, mulheres na Física.

f. Mostra de Cursos da UnB: parte da referida Semana Universitária, consistiu em um stand no qual os licenciandos apresentaram o curso para alunos do Ensino Médio do DF. 
No CEM Setor Leste (Brasília), foram realizados, especificamente:

a. Feira de ciências: ocorrida de maio a agosto, tematizou as criações de Leonardo da Vinci. Alunos da escola escolheram invenções malsucedidas para tentar reconstruí-las e compreender o motivo de sua falha à época. Além das maquetes foram apresentados trabalhos escritos sobre as leis físicas envolvidas nos inventos. Durante o período de aula diurno, os trabalhos foram expostos.

b. Acompanhamento visando ao Programa de Avaliação Seriada da UnB (PAS) e ao Enem, realizado em agosto e setembro, no contraturno. Não foi comentado o desempenho dos alunos da escola nas avaliações, pois elas ainda não haviam sido aplicadas.

c. Participação em avaliações: participação dos licenciandos nas avaliações realizadas pela supervisora no período de julho a setembro, com discussão de critérios, construção e correção de exercícios, exames e trabalhos escritos.

d. Acompanhamento pedagógico: de setembro a novembro, alunos das turmas de segundo ano tiveram horários no contraturno para discutirem suas dúvidas com licenciandos.

e. Atividades experimentais: nos dias 6 e 7 de agosto, foram abordados conceitos de Óptica Geométrica - espelhos planos e esféricos, lentes convergentes e divergentes, câmera escura, princípio da fibra óptica e eclipse. Não estão mencionados os experimentos.

No CED 02 (Cruzeiro), as atividades realizadas em 2014 foram as seguintes:

a. Reforço objetivando PAS e Enem: resolução de questões dos exames para familiarizar os alunos; ocorreu de agosto a setembro.

b. Atividades experimentais: durante o segundo semestre, os licenciandos trabalharam experimentos relacionados a Física Térmica e a Circuitos Elétricos. Não foram especificados os experimentos.

c. Tópicos de Astronomia: aulas expositivas, realizadas de março a junho, que tematizaram origem e organização do universo, atributos de planetas e planetas anões, buracos negros, Relatividade, paradoxo dos gêmeos, 
formação de estrelas e meteoros. Com base nessa prática, os licenciandos escreveram um artigo aprovado no XXI Simpósio Nacional de Ensino de Física, previsto para janeiro de 2015.

d. Acompanhamento pedagógico: de setembro a novembro, licenciandos trabalharam no contraturno com dúvidas dos alunos.

No Cemab (Taguatinga), as atividades específicas foram:

a. Atividades experimentais: em outubro e novembro, o tema Gravitação Universal foi abordado por meio da observação do céu durante o dia com um telescópio newtoniano, com demonstração da distância entre planetas do Sistema Solar em escala reduzida e determinação da excentricidade da elipse.

b. Atividades para alunos cegos: de setembro a novembro, foram desenvolvidos materiais voltados para alunos com baixa visão sobre Gravitação e Astronomia. Não estão discriminados os materiais.

c. Avaliação das atividades: os alunos das escolas foram convidados a responder um questionário de avaliação, no qual sugeriram atividades para o ano seguinte. Não estão relacionadas as atividades sugeridas.

d. Acompanhamento pedagógico: horário reservado no contraturno para tirar dúvidas.

O relatório registra as seguintes atividades do subprojeto no CEM 09 (Ceilândia):

a. Atividades experimentais: montagem de circuitos elétricos em série e em paralelo; ocorreu em novembro.

b. Revitalização de laboratório: citada como uma das primeiras atividades realizadas na escola, ocorreu de julho a agosto e consistiu na limpeza e organização do local e dos materiais. Após o trabalho, o espaço foi considerado pronto para uso.

c. Acompanhamento pedagógico: de agosto a novembro, alunos que se encontravam em situação de dependência (não aprovados no ano anterior na disciplina de Física) frequentaram a escola no contraturno. As atividades realizadas foram escritas de redação sobre a Física no dia-a-dia; 
experimento sobre velocidade média; experimento sobre PVT (pressão, volume, temperatura); exercícios de Matemática básica e Física Térmica; abordagem de questões do Enem; reprodução, discussão e escrita de texto sobre os documentários "Como funciona o universo: Estrelas" e "Cosmos episódio 8".

\subsubsection{Produções, impactos dificuldades e considerações finais}

O relatório segue informando as produções educacionais geradas em 2014 . Classificados como "produções didático-pedagógicas", estão os registros fotográficos das escolas CEM 09 (Ceilândia) e Cemab (Taguatinga), com um total de 16 imagens. A produção bibliográfica listada é o trabalho aceito para apresentação no XXI Simpósio Nacional de Ensino de Física. Não constam produções artístico-culturais, desportivas e lúdicas, técnicas e de infraestrutura.

Para o subprojeto, os impactos de suas ações residiram no conhecimento da realidade de uma unidade pública de ensino por parte dos licenciandos, na possibilidade de reflexão sobre sua prática e na reorientação do trabalho escolar, no caso dos supervisores. Os alunos das escolas parceiras teriam melhorado seu desempenho na disciplina, o que teria aumentado seu interesse. A contribuição para a licenciatura em Física teria sido o reconhecimento como um curso de identidade própria, diverso do bacharelado e da Física Computacional, os outros cursos ofertados no Instituto de Física. Além disso, a presença do subprojeto nas escolas teria sido a motivação para que dois dos atuais bolsistas ID escolhessem a licenciatura no processo seletivo da UnB.

As dificuldades encontradas pelos participantes para a realização das atividades foram: material, pois a verba da Capes permite apenas aquisição de materiais de uso corrente, impossibilitando a estruturação de laboratórios; e cotidiano das escolas, com horários reduzidos, feriados e grades horárias por vezes incompatíveis com os horários dos licenciandos. Foram relatadas interrupções no fornecimento de água, motivo para liberação dos alunos, salas sucateadas e falta de 
laboratórios. Outra dificuldade, essa interna ao subprojeto, também está relacionada à conciliação de horários, mas entre coordenadoras, supervisores e bolsistas ID.

Em suas considerações finais, as coordenadoras do subprojeto destacam o esforço dos licenciandos em aplicar, na escola, materiais desenvolvidos em reuniões e oficinas, e em auxiliar o professor supervisor nas aulas. Os supervisores figuram no relatório como protagonistas, sendo propositores das ações orientadas para a construção do próprio conhecimento pelos futuros docentes.

Para além do contato com a realidade escolar, muitas vezes mencionado, são resultados positivos na formação dos licenciandos o trabalho em equipe, o melhor domínio de conceitos científicos e a segurança em ensinar. O relatório se encerra apresentado suas perspectivas: continuar projetos em andamento, realizar oficinas preparatórias para interessados em participar da Olímpiada Brasileira de Física e articular ações preparatórias para o Enem com os subprojetos de Biologia, Matemática e Química.

\subsubsection{Notas analíticas sobre o relatório de atividades do subprojeto Pibid Física UnB relativo ao ano de 2014}

Na seção 4.1.5, mostramos que a proposta do subprojeto Pibid Física UnB guarda coerência com os objetivos do programa. Naquele documento, mesmo sendo enfatizada a realização de atividades de apoio docente em sala de aula ao longo do texto, está perceptível, na breve exposição dos resultados da edição anterior do subprojeto, que as atividades vão além das aulas expositivas.

A partir da análise do relatório de atividades de 2014, podemos afirmar que as ações realizadas, de modo geral, implementam com sucesso as intenções do programa público, pois se concentram em inserir os bolsistas no cotidiano das escolas. Pontuaremos a seguir alguns elementos para compreender em que medida 0 subprojeto ainda pode melhorar seu trabalho formativo, considerando nossa experiência de gestão na Capes.

O relatório afirma ter sido a primeira atividade de todos os bolsistas ID a "caracterização da escola", a qual teria resultado na formulação de ações voltadas 
para as condições de cada espaço, a exemplo da revitalização do laboratório do CEM 09 e das atividades para deficientes visuais. Essa caracterização poderia gerar um produto sucinto a ser apresentado em anexo digital juntamente com o relatório, incluindo fotografias e vídeos feitos por licenciandos e integrantes das escolas. De fato, seria mais um exercício de expressão e uma produção educacional a mais que poderia gerar outras, mesmo de natureza acadêmica.

Quanto às atividades de observação de aulas e o trabalho a ser apresentado em evento acadêmico, cabem algumas ponderações. Sobre as observações e a atuação em classe, mesmo que de forma auxiliar, existe uma discussão segundo a qual seria o Pibid frequentemente confundido com o estágio supervisionado no cotidiano dos projetos institucionais. Nessa sobreposição, o estágio tem sido por vezes prejudicado.

Estudo recente de Jardilino (2014) revela que estagiários têm sido mesmo preteridos por professores de escolas em detrimento de bolsistas do Pibid - pois atuar no Pibid garante bolsas e recursos para atividades. O pesquisador aponta que mesmo a linguagem do MEC chega a ser ambígua no uso do termo "estágio" ao se referir ao programa. Portanto, o risco de sobreposição existe, e o subprojeto pode tentar marcar mais explicitamente o diferencial da atuação em sala em relação à do estágio.

Uma das características mais relevantes do subprojeto Pibid Física UnB é o fato de ele não incluir a pesquisa como atividade. Não é incomum que projetos Pibid assumam um caráter de investigação, fazendo do espaço escolar uma espécie de laboratório no qual serão testados materiais e metodologias. Em outros casos, os bolsistas ID devem, como uma de suas tarefas, realizar coleta de dados para pesquisas das quais os coordenadores institucionais são integrantes. Durante algumas tentativas de análises de prestações de contas das quais participamos na Capes como equipe técnica, apreciamos relatórios que pouco mencionavam realizações dos bolsistas nas escolas, mas elencavam um rol de participações em eventos acadêmicos, por vezes internacionais, como suas principais atividades.

A pesquisa docente não é vetada no Pibid, ao contrário da regência de classe. Contudo, a ênfase na investigação como atividade rotineira traz o risco de dispersar esforços dos licenciandos, os quais deveriam estar voltados para agir criativamente 
em conjunto com o meio escolar. Um efeito adicional de priorizar a investigação no Pibid é a alocação de montantes elevados para custear organização e participação em eventos acadêmicos, os quais, ressalvamos, são oportunidades de ter contato com outras experiências, mas não podem ser finalidade primeira, apenas consequência de um trabalho nas escolas.

O subprojeto Pibid Física UnB demonstra priorizar o essencial do Pibid: atuação nas escolas, produção de material didático como forma de exploração criativa e estímulo do interesse dos alunos das escolas a ingressar em curso de licenciatura. Dessa prática resulta sua produção acadêmica, mesmo porque o exercício de composição de textos está previsto como estratégia para aprimorar a expressão dos licenciandos.

Não somos contrários à prática de auxílio ao professor em classe no âmbito do Pibid, nem dos apoios pedagógicos realizados em contraturno. Semelhantemente a atividades de pesquisa, a prática de aulas não é o foco do programa; contudo, estabelecer uma fronteira estanque na ação dos projetos pode impactar negativamente. Acreditamos que a atuação em sala de aula pode auxiliar na elaboração de atividades inovadoras, as quais muitas vezes não serão sequer aplicadas entre paredes.

O exercício da docência no Pibid é uma questão controversa. A proposta do programa parece incentivar a prática de atividades inovadoras. Contudo, a falta de uma devolutiva da Capes para as instituições sobre os resultados das ações dos projetos dificulta o entendimento sobre o que seriam essas inovações. Sem orientação sobre suas próprias atividades, os projetos tendem a reiterar uma "prática de saber-fazer conservadora, prescritiva e ritualizada" (GAUTHIER, 2010), na qual o aprendizado consiste em uma transmissão de conteúdo de um ente iluminado pelo saber - o professor - em direção a receptores/assimiladores opacos - alunos.

Se o Pibid demanda inovação, precisa defini-la; e fazê-lo passa necessariamente por delinear os espaços de interseção entre a pedagogia tradicional e a "nova cultura educacional", tal como está proposta pelo Relatório de Gestão da DEB (Capes, 2014). O que é admissível e o que não deve ser praticado? Quais as boas práticas? Essas são perguntas deixadas em aberto pelos documentos da 
Capes, mas cujas respostas devem ser fornecidas pelo órgão em consenso com os projetos.

Uma das ações previstas foi a produção de material didático. Contudo, da seção destinada a descrever o material produzido, consta apenas um par de registros fotográficos das escolas CEM 09 e Cemab, e nenhuma referência às outras duas unidades de ensino. A única remissão direta a algum material consta do relato das atividades no Cemab, em que há informação sobre um material voltado para deficientes visuais, sem mais detalhes. Talvez não tenha sido possível construir os materiais da forma esperada, mas isso deveria ser notificado na seção dedicada ao relato das dificuldades encontradas.

A recuperação de laboratórios constava da proposta ampliada e foi excluída do subprojeto inscrito. Essa atividade foi realizada de fato no CEM 09, mas não fez parte da lista de produções. Ficaram de fora dessa lista as atividades experimentais e a feira de ciências. Nos próximos relatórios, essa seção precisa receber mais atenção, para tornar mais simples a tarefa de identificar os produtos.

Não houve qualquer referência ao uso de tecnologias de informação e comunicação e à abordagem de temas socioambientais, contrariando a previsão da proposta inscrita. Novamente o subprojeto não discute a ausência no relatório de um item previsto na proposta. Podemos afirmar que a pouca produção didáticopedagógica, ou mais especificamente, de material didático é a principal deficiência identificada no subprojeto, pois essa é ação mais detalhada na proposta, o que nos leva a entender que seria o foco da proposição.

Para demonstrar o uso de uma metodologia de trabalho baseada na aprendizagem colaborativa, o subprojeto poderia usar o relatório para especificar qual abordagem conceitual de AC the serve de fundamento. Adicionalmente, cabe discorrer, mesmo de maneira sucinta, como está sendo implementada essa aprendizagem no decorrer do ano letivo. Uma maneira de iniciar a reflexão é responder às seguintes perguntas, as quais propomos a partir da definição ampla de AC apresentada por Dillenbourg (1999): quem são os envolvidos no processo de AC? Qual a noção de aprendizado? O que significa, então, "aprender junto"? 
Ao discutir sua metodologia, o subprojeto pode auxiliar o projeto institucional, escolas, secretarias de educação, a área de Ensino de Física e a Capes a compreenderem os resultados da política. A experiência prática do Pibid enriquece o debate de cunho acadêmico sobre aprendizagem colaborativa. O exercício de reflexão sobre essa metodologia pode ser incluído entre os trabalhos de aprimoramento de comunicação e expressão, dado que o subprojeto já dispõe desse espaço para a reflexão acadêmica sobre as atividades.

Encontra-se difusa no subprojeto a natureza da relação entre universidade e escola, e isso também é perceptível no relatório de atividades. Por um lado, o subprojeto deixa a entender que os integrantes da escola estarão presentes nas tomadas de decisão, mas não detalha quem forma a "comunidade escolar". Consequência dessa indefinição é a falta de clareza sobre o papel assumido por cada membro da comunidade na articulação das ações. Proceder à conceituação de aprendizagem colaborativa pode ajudar a definir a natureza dessa relação.

Naturalmente, foram encontradas contrariedades na implementação do subprojeto. A primeira diz respeito à compra de material permanente para a construção de conjuntos laboratoriais com o objetivo de viabilizar a realização de experimentos. De fato, apesar de o regulamento do programa prever a possibilidade do repasse de verba de capital (CAPES, 2013a), a disponibilidade orçamentária do programa não contemplou recursos para aquisição de bens duráveis. Uma alternativa para conseguir os materiais é buscar outras parcerias, primeiramente com a própria universidade, não podendo ser descartado o contato com empresas e organizações do terceiro setor.

A precariedade da infraestrutura das escolas públicas é uma questão nacional, bem como os problemas de natureza organizacional relacionados a mudanças de horários sem avisos prévios. Mesmo as condições urbanas afetam o funcionamento escolar, como cortes no abastecimento de água. Um diálogo mais próximo e frequente com o corpo administrativo pode minimizar desencontros.

Em relação aos resultados obtidos no ano de 2014, já destacamos a efetiva inserção dos licenciandos no cotidiano escolar, cujo efeito ultrapassa 0 desenvolvimento e a aplicação de materiais e métodos de ensino, mas efetivamente 
estimula os alunos das escolas a se interessarem pela disciplina. A maior comprovação do aumento do estímulo é o ingresso de dois ex-alunos na licenciatura de Física após terem contato com o Pibid. A presença dos licenciandos também movimenta o espaço das unidades de ensino, com a realização de feiras de ciências e a recuperação de laboratórios.

Em 2015, o subprojeto prevê a oferta de oficinas preparatórias para a participação na Olimpíada Brasileira de Física e a busca de outros subprojetos para articulação de ações conjuntas - desafios coerentes com a proposta do programa. Reiteramos a proposição de buscar aproximação com o corpo técnico e com a comunidade em torno da escola. Outra proposta a ser considerada é a realização de atividades conjuntas com outras escolas participantes do Pibid na região CentroOeste. 


\section{CONSIDERAÇÕES FINAIS}

Nossa incursão investigativa a respeito do subprojeto Pibid Física UnB nos permitiu perceber, por meio da análise do relatório de atividades relativo ao ano de 2014, que existe um alinhamento das ações do subprojeto à proposta de formação em licenciatura fomentada pela política pública chamada Programa Institucional de Bolsa de Iniciação à Docência. De modo geral, o subprojeto realiza com sucesso a inserção dos licenciandos nas escolas públicas de educação básica para 0 desenvolvimento de atividades criativas, envolvendo docentes em exercício e professores universitários, de modo a estreitar a relação entre universidade e escola.

Essa aderência ao programa é fundamental por dois motivos. Primeiramente, trata-se de um indício - com todas as limitações inerentes a um estudo de caso - de que a proposta do Pibid é factível, e não apenas mais um amontoado de boas intenções de agentes governamentais, desprovido de operabilidade. Segundo, demonstra que o investimento público na proposta do Pibid pode gerar resultados positivos para a formação dos futuros professores das escolas públicas de educação básica. Ou seja, os elementos analisados apontam para um bom emprego das verbas destinadas à educação, e isso merece destaque em um país caracterizado por desvios administrativos em todas as esferas de governo.

Reiteramos que o subprojeto demonstra realizar o cerne da propositura do Pibid: busca, principalmente, fazer os licenciandos desenvolverem atividades nos ambientes escolares; estimula a opção pelo curso de licenciatura; agrega criatividade e experimentação à formação; e mobiliza escolas públicas, tornando-as parte do processo formativo dos futuros professores. Contudo, é necessário que o subprojeto trabalhe melhor algumas questões de modo a reforçar sua ação formativa.

O ponto principal a ser observado é a atuação dos licenciandos em sala de aula, com observação dos supervisores e reforço de conteúdos em contraturno. Existe uma discussão nas licenciaturas sobre a sobreposição do Pibid ao estágio curricular, e a preocupação com essa confusão deve ser constante. $O$ subprojeto parece enfatizar bastante a presença dos licenciandos em sala de aula, de modo que 
a criatividade possibilitada pelo desenho do programa corre o risco de não ser explorada caso a ênfase das atividades seja reiterar o fazer docente "tradicional".

Na proposta do subprojeto, a atividade mais claramente definida é a produção de material didático; entretanto, notamos uma única referência a material didático produzido pelos licenciandos. Por ser essa uma ação que trabalha bastante a criatividade, deve receber mais atenção nos anos subsequentes, com uma discussão mais aprofundada sobre o processo, desde a construção até o uso. Relacionado ao trabalho com materiais está o uso de tecnologias de informação e comunicação, o qual não foi mencionado no relatório. Trabalhar com as TIC deixou de ser opção? Por quê? $\mathrm{Na}$ sociedade de informação em que vivemos, é possível prescindir desses recursos em um ambiente formativo?

Outra ponderação que cabe ao subprojeto diz respeito à relação entre universidade e escola. Apesar de ser perceptível o envolvimento das unidades de ensino de uma forma participativa e não passiva, não ficou claro o nível dessa participação. Termos usados no relatório, como "comunidade escolar", carecem de detalhamento: quem forma a comunidade de cada escola? Quais figuras estão mais envolvidas nas atividades? Alguma proposição por parte da escola pautou o projeto? Existe envolvimento dos pais dos alunos?

A questão anterior nos remete à metodologia norteadora do subprojeto mencionada na proposta, a aprendizagem colaborativa. Existe uma miríade de conceituações de $A C$ na literatura, mas no subprojeto não está bem definida qual abordagem será trabalhada. Definir um ponto de referência pode trazer mais clareza para a relação que o subprojeto deseja manter com a escola, além de abrir uma discussão frutífera para o campo de conhecimento, a partir da aplicação de um conceito em um caso concreto.

Discorremos sobre um subprojeto do Pibid. Contudo é necessário abordar também o ponto mais frágil na proposta do programa: a intenção de "valorizar" a profissão docente, expressa em todos os documentos regulatórios do programa e nos editais. Apesar de a oferta de uma formação sólida ser um componente importante na composição de uma carreira, valorização profissional significa, antes de tudo, remunerar adequadamente. 
Neste estudo, buscamos inicialmente remontar histórica e politicamente a formação de professores no Brasil. Esse olhar para o passado nos permite considerar o contexto atual das políticas públicas de formação de professores - compreendido desde 2007 até 2015 -, o mais diretivo em relação às ações de valorização docente, do ponto de vista da ação estatal, tanto regulatória, quanto executiva.

Não se pode dizer, contudo, que o professor seja atualmente valorizado de facto por sua atuação profissional. A remuneração permanece baixa em relação a outras profissões, como assinalam Mizala e Ñopo (2014), comparando salários de professores de 13 países latino-americanos nos anos de 1997 e 2007. Mesmo após o estabelecimento de um piso salarial nacional, em 2008, o salário dos professores em 2009 correspondia em valor ao ordenado fixado em 1827 (PINTO, 2009).

Barbosa (2012), por sua vez, aponta uma reação em cadeia a partir dos baixos salários sobre a profissão: ampliação da jornada para compensar a reduzida remuneração, que traz consigo o aumento da rotatividade e a itinerância dos professores entre escolas, com consequências maléficas para a saúde dos docentes, e, logo, para o aprimoramento profissional. Portanto, não é possível falar em real valorização dos professores antes de pagar salários condizentes com a importância da função (PINTO, 2009).

Por outro lado, a justiça salarial por si mesma não alavanca a qualidade da educação básica. É preciso professores com sólida formação para garantir o aprendizado dos alunos, e essa formação depende do contato direto e prolongado com a realidade escolar. Darling-Hammond (2000) apresenta extensa literatura que evidencia a importância de uma preparação para a docência realizada dentro das unidades de ensino para melhorar o aprendizado dos alunos. Para a autora, uma formação que também estimule a prática reflexiva terá resultados mais significativos.

Fazemos, contudo, uma ressalva quanto ao impacto per se da qualidade da formação do professor no aprendizado dos alunos. Relatório de um estudo multilateral sobre professores de escolas conduzido pela Organisation for Economic CoOperation and Development (OECD) alerta para a complexidade de fatores concorrentes na questão. O estudo, em colaboração com 25 países de todos os continentes, aponta que a maior fonte de variação no aprendizado de alunos pode ser 
atribuída a elementos concernentes a eles próprios, como suas expectativas, habilidades e histórico familiar. Influir nesses fatores é difícil para as políticas públicas (OECD, 2005).

O estudo acrescenta que, dentre as variáveis mais suscetíveis de influência pelas políticas públicas, aquelas envolvendo professores e docência são as mais relevantes para o aprendizado dos alunos. Contudo, a falta de consenso acadêmico sobre as variáveis a testar e seu peso demandam cuidado na interpretação dos resultados de qualquer pesquisa sobre o assunto. Um consenso nos estudos é o de que os indicadores mais usados não captam aspectos cruciais para garantir aprendizado: traduzir ideias em formas mais simples; criar ambientes propícios ao aprendizado para variados tipos de estudantes; ser criativo e atuar com entusiasmo; estabelecer interações produtivas com alunos; trabalhar em equipe com colegas (OECD, 2005).

A Capes recomenda a escolha de escolas com perfis distintos: aquelas com resultados no Ideb inferiores à média nacional e outras que sejam consideradas referências de ensino e aprendizagem. O propósito é enriquecer a compreensão da realidade educacional. Outro objetivo é contribuir com a elevação do índice (CAPES, 2013a. Uma vez que o resultado do Ideb está disponível por escola apenas para o Ensino Fundamental, sendo divulgado o dado relativo ao Ensino Médio apenas em nível de UF, não é possível selecionar escolas de EM segundo esse critério.

Considerando que o EM apresenta os piores resultados no ldeb dentre os níveis de ensino desde a primeira divulgação do índice, em 2005, faz-se necessário o diálogo entre Capes e Inep para a publicação desse dado. Caso contrário, não será possível avaliar o impacto da Política Nacional de Formação dos Profissionais do Magistério da Educação Básica.

Ao falar de "impacto", precisamos fazer uma observação de cunho conceitual sobre o uso deste termo na seção de n. 6 do modelo de relatório (CAPES, 2012). Nessa subdivisão do formulário, é solicitada uma relação de impactos do subprojeto em uma série de aspectos e espaços formativos, tanto da universidade quanto da educação básica. Conforme Secchi (2011), "impacto" se refere a resultados de um programa público, identificados em longo prazo. Solicitar de um projeto institucional 
uma avaliação dessa magnitude parece uma inversão dos papéis entre o gestor e 0 operador da política pública. A Capes é a instituição responsável pelo investimento público; naturalmente ela é quem deve liderar um processo avaliativo de impactos, e não legar a tarefa aos próprios participantes, os beneficiados pelos recursos financeiros.

Existe ainda um espaço no modelo de relatório destinado à inserção do "indicador da atividade". Sobre esse ponto, precisamos fazer uma consideração de ordem conceitual. Essa coluna do formulário serve claramente para apenas numerar as atividades, de forma a indexá-las e tornar a referência a elas mais simples e eficaz (ex.: "atividade 2.1"). Desse modo, o uso do termo "indicador" parece estar descolado de seu conceito. Recorremos a Januzzi (2001), para compreender que o significado de indicador social, que é:

[...] uma medida em geral quantitativa dotada de significado social substantivo, usado para substituir, quantificar ou operacionalizar um conceito social abstrato, de interesse teórico (para pesquisa acadêmica) ou programático (para formulação de políticas).

Portanto, o uso do termo "indicador" é inadequado nesse caso, pois a numeração escrita nessa coluna tem emprego puramente referencial; não possui significado substantivo nem conceito associado, elementos essenciais para se criar um indicador. Devido à ampla aceitação do conceito de indicador, sintetizado no trecho do pesquisador citado, nos meios acadêmico, econômico e de gestão pública, entendemos que a Capes deve considerar a substituição do rótulo de coluna da seção relativa às atividades no modelo do relatório.

Outro agravante no emprego do termo é o contexto em que ele está inserido, um relatório de atividades, elemento a ser considerado em uma possível avaliação do programa público. $\mathrm{Na}$ atividade de gestão do programa, recebemos muitos telefonemas e mensagens de coordenadores questionando o que preencher na coluna, pois estavam familiarizados com o conceito. A principal dúvida era: "preciso criar indicadores de qualidade para avaliar os resultados"? Recomendamos rotular a coluna apenas como "Atividade". Desse modo, ficaria claro que se trata apenas de uma referência. 
Após levantar tantas questões relativas às atividades desenvolvidas no subprojeto Pibid Física UnB, queremos reiterar nossa intenção de contribuir com a formação de professores por meio do debate sobre realizações dos objetivos do programa e potencialidades dessa política pública. Lançar mão de nosso olhar "interno" da Capes é uma tentativa de apontar para uma continuidade entre a gestão pública e o cotidiano de escolas e instituições de educação superior.

Entendemos o Pibid como uma tentativa de tornar mais orgânica a educação brasileira, tão desagregada por regulamentos conflitantes e boas intenções de gabinetes políticos, mas pouco atenta aos professores e aos futuros docentes. Sem dúvida, conforme pontuamos, o programa reflete essa maneira de ser da gestão pública nacional - pouco afeita a planejamentos e avaliações, deficiente de sistemática; contudo, a investigação de um caso particular da implementação, o subprojeto Pibid Física UnB, fornece insumos para acreditarmos no aperfeiçoamento da formação de professores nessa disciplina fundamental para a formação secundária. 


\section{REFERÊNCIAS}

ALBUQUERQUE, Fernanda Menezes de; GALIAZZI, Maria do Carmo. Histórias de sala de aula: Pibid sinalizando para a produção de currículo na licenciatura. Química Nova na Escola, São Paulo, v. 35, n. 1, fev. 2013.

BORGES, Antonio Tarciso. Novos Rumos para o Laboratório Escolar de Ciências. Caderno Brasileiro de Ensino de Física, Florianópolis, v. 19, n.3, p. 291-313, dez. 2002. Disponível

em: <https://periodicos.ufsc.br/index.php/fisica/article/viewFile/6607/6099>.

BARBOSA, Andreza. Implicações dos baixos salários para o trabalho dos professores brasileiros. Revista Educação e Políticas em Debate, Uberlândia, v. 1, n. 2, 2012. Disponível em: <http://www.seer.ufu.br/index.php/revistaeducaopoliticas/article/view/21902/12112>.

BRASIL. Decreto n. 7.566, de 23 de setembro de 1909. Crêa nas capitaes dos Estados da Republica Escolas de Aprendizes Artifices, para o ensino profissional primario e gratuito. Lex: Câmara dos Deputados, [20-]. Disponível em: <http://www2.camara.leg.br/legin/fed/decret/1900-1909/decreto-7566-23-setembro1909-525411-publicacaooriginal-1-pe.html>.

BRASIL. Lei n. 9.394, de 20 de dezembro de 1996. Estabelece as diretrizes e bases da educação nacional. Lex: Casa Civil, [20-]. Disponível em: <http://www.planalto.gov.br/ccivil_03/leis/19394.htm>.

BRASIL. Lei n. 11.738, de 16 de julho de 2008. Regulamenta a alínea "e" do inciso III do caput do art. 60 do Ato das Disposições Constitucionais Transitórias, para instituir o piso salarial profissional nacional para os profissionais do magistério público da educação básica. Diário Oficial da União. Brasília: Casa Civil da Presidência da República, 2008a. Disponível em: <http://www.planalto.gov.br/ccivil_03/_ato20072010/2008/lei/l11738.htm>. Acesso em: 4 out. 2012.

BRASIL. Lei n. 11.892, de 29 de dezembro de 2008. Institui a Rede Federal de Educação Profissional, Científica e Tecnológica, cria os Institutos Federais de Educação, Ciência e Tecnologia, e dá outras providências. Diário Oficial da União. Brasília: Casa Civil da Presidência da República, 2008b. Disponível em: <http://www.planalto.gov.br/ccivil_03/_ato2007-2010/2008/lei//11892.htm>.

BRASIL. Decreto n. 6.755, de 29 de janeiro de 2009. Institui a Política Nacional de Formação de Profissionais do Magistério da Educação Básica, disciplina a atuação da Coordenação de Aperfeiçoamento de Pessoal de Nível Superior - CAPES no fomento a programas de formação inicial e continuada, e dá outras providências. Brasília: Casa Civil, 2009. Disponível em: <http://www.planalto.gov.br/ccivil_03/_ato20072010/2009/decreto/d6755.htm>. 
BRASIL. Decreto n. 7.219, de 14 julho de 2010. Dispõe sobre o Programa Institucional de Bolsa de Iniciação à Docência - PIBID e dá outras providências. Brasília: Casa Civil, 2010. Disponível em:

<http://www.capes.gov.br/images/stories/download/legislacao/Decreto7219_Pibid_240 610.pdf>.

BRASIL. Lei $\mathbf{n}$. 12.858, de 9 de setembro de 2013. Dispõe sobre a destinação para as áreas de educação e saúde de parcela da participação no resultado ou da compensação financeira pela exploração de petróleo e gás natural, com a finalidade de cumprimento da meta prevista no inciso VI do caput do art. 214 e no art. 196 da Constituição Federal; altera a Lei oํ 7.990, de 28 de dezembro de 1989; e dá outras providências. Brasília: Casa Civil, 2013. Disponível em <http://www.planalto.gov.br/ccivil_03/_Ato2011-2014/2013/Lei/L12858.htm>

BRASIL. Lei no 13.005, de 25 de junho de 2014. Aprova o Plano Nacional de Educação (PNE) e dá outras providências. Brasília, DF: Casa Civil, 2014. Disponível em <http://www.planalto.gov.br/ccivil_03/_Ato2011-2014/2014/Lei/L13005.htm>.

COMPANHIA DE PLANEJAMENTO DO DISTRITO FEDERAL (CODEPLAN). Perfil da distribuição dos postos de trabalho no Distrito Federal: concentração no plano piloto e déficits nas cidades-dormitório. Brasília: Codeplan, abr. 2013. Disponível em: http://www.codeplan.df.gov.br/images/CODEPLAN/PDF/Pesquisas\%20Socioecon\%C 3\%B4micas/2013/PERFIL\%20DA\%20DISTRIBUI\%C3\%87\%C3\%83O\%20DOS\%20P OSTOS\%20DE\%20TRABALHO\%20NO\%20DISTRITO\%20FEDERAL\%20\%202\%20ABRIL.pdf.

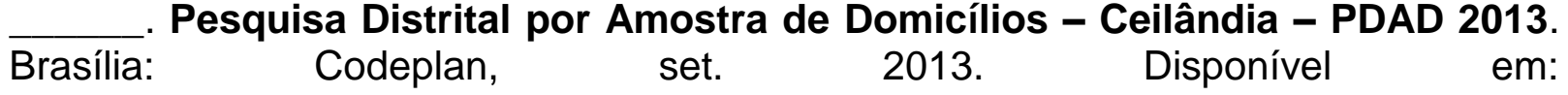
<http://www.codeplan.df.gov.br/images/CODEPLAN/PDF/Pesquisas\%20Socioecon\% C3\%B4micas/PDAD/2013/Ceil\%C3\%A2ndia-PDAD\%202013.pdf>.

$\begin{array}{cccc} & \text { Pesquisa Distrital por Amostra de Domicílios - Taguatinga - PDAD } \\ \text { 2013. } & \text { Brasília: Codeplan, dez. } 2013 . & \text { Disponível } & \text { em: }\end{array}$ <http://www.codeplan.df.gov.br/images/CODEPLAN/PDF/pesquisa_socioeconomica/p dad/2013/PDAD_Taguatinga_2013.pdf>.

Pesquisa Distrital por Amostra de Domicílios
$\begin{aligned} & \text { Brasília: Cruzeiro - PDAD/2014. } \\ & \text { Codeplan, }\end{aligned}$ mar.
<http://www.codeplan.df.gov.br/images/CODEPLAN/PDF/pesquisa_socioeconomica/p
dad/2013/PDAD_CRUZEIRO_2014.pdf>.

. Pesquisa Distrital por Amostra de Domicílios - Brasília/Plano Piloto PDAD/2014. Brasília: Codeplan, nov. 2014. Disponível em: <http://www.codeplan.df.gov.br/images/CODEPLAN/PDF/pesquisa_socioeconomica/p dad/2013/PDAD_Brasilia_Plano_Piloto_2014.pdf >. 
. Pesquisa Distrital por Amostra de Domicílios - Distrito Federal PDAD/DF 2013. Brasília: Codeplan, dez. 2014. Disponível em: $<$ http://www.codeplan.df.gov.br/images/CODEPLAN/PDF/pesquisa_socioeconomica/p dad/2013/PDAD-DF_2013_1.pdf>.

CONSELHO NACIONAL DE EDUCAÇÃO (CNE). Parecer CNE/CES n. 1.304/2001. Diretrizes curriculares nacionais para os cursos de Física. Brasília: CNE, 2001. Disponível em: <http://portal.mec.gov.br/cne/arquivos/pdf/CES1304.pdf>.

. Resolução CNE/CP n. 1, de 18 de fevereiro de 2002. Institui diretrizes curriculares nacionais para a formação de professores da educação básica, em nível superior, curso de licenciatura, de graduação plena. Brasília, DF, CNE, 2002a. Disponível em: <http://portal.mec.gov.br/cne/arquivos/pdf/rcp01_02.pdf>.

. Resolução CNE/CES n. 9, de 11 de março de 2002. Estabelece as diretrizes curriculares para os cursos de bacharelado e licenciatura em Física. Brasília: CNE, 2002b. Disponível em: <http://portal.mec.gov.br/cne/arquivos/pdf/CES09-2002.pdf>.

CORREIA, Gerson dos Santos. Estudo dos conhecimentos evidenciados por alunos dos cursos de licenciatura em Matemática e Física participantes do Pibid-PUC/SP. 2012. 127 f. Dissertação (Mestrado em Educação Matemática) Programa de Estudos Pós-Graduados em Educação Matemática, Pontifícia Universidade Católica de São Paulo, São Paulo, 2012.

COZZA, Fabio Espindola. Modelagem matemática: percepção e concepção de licenciandos e professores. 2013. 97 f. Dissertação (Mestrado em Educação Matemática)-Programa de Pós-Graduação em Educação em Ciências e Matemática, Pontifícia Universidade Católica do Rio Grande do Sul, Porto Alegre, 2013.

CRESWELL, John W. Qualitative inquiry and research design: Choosing among five approaches. 2nd. ed. Thousand Oaks: Sage Publications, 2007.

CRESWELL, John W. Educational research: planning, conducting, and evaluating quantitative and qualitative research. 4th ed. Boston: Pearson, 2012.

CRUZ, Tatiana de Mello Ribeiro. Programa de Bolsas de Iniciação à DocênciaFilosofia/UFSM: dispositivo de práticas docentes. 2012. 116 f. Dissertação (Mestrado em Educação) - Programa de Pós-Graduação em Educação, Universidade Federal de Santa Maria, Santa Maria, 2012.

DARLING-HAMMOND, Linda. How Teacher Education Matters. Journal of Teacher Education, v. 51, n. 3, p. 166-173, May, 2000. doi: 10.1177/0022487100051003002.

DINIZ-PEREIRA, Júlio Emílio. As licenciaturas e as novas políticas educacionais para a formação docente. Educação e Sociedade, Campinas, v. 68, p. 109-125, 1999. Disponível em: <http://www.scielo.br/pdf/es/v20n68/a06v2068.pdf>. 
DILLENBOURG, Pierre. What do you mean by collaborative learning? In: DILLENBOURG, Pierre (Org.). Collaborative learning: Cognitive and Computational Approaches. Oxford: Elsevier, 1999. p. 1-19. Disponível em: <http://tecfa.unige.ch/tecfa/publicat/dil-papers-2/Dil.7.1.14.pdf>.

DORNELLES, Aline Machado; GALIAZZI, Maria do Carmo. Histórias de Sala de Aula de Professoras de Química: Partilha de Saberes e de Experiências nas Rodas de Formação do PIBID/FURG. Química Nova na Escola, São Paulo, v. 34, n. 4, p. 256265, nov. 2012.

DORNELES, Aline Machado. A roda dos bordados da formação: o que bordam as professoras de química nas histórias de sala de aula? 2011. 105 f. Dissertação (Mestrado em Educação em Ciências: Química da Vida e Saúde) - Programa de PósGraduação em Educação em Ciências: Química da Vida e Saúde, Universidade Federal do Rio Grande, Rio Grande, 2011.

EISENHARDT, Kathleen M. Building theories from case study research. The Academy of Management Review. Briarcliff Manor, NY, v. 14, n. 4, p. 532-550, oct. 1989. Disponível em: <http://www.buseco.monash.edu.au/mgt/research/acrew/eisenhardt.pdf>.

FABRIS, Eli Henn; OLIVEIRA, Sandra. Pibid e as aprendizagens sobre a docência na relação universidade e escola. Linhas Críticas, Brasília, v.19, n.39, p. 429-448, maioago. 2013.

FEIJOLO, Thomas Barbosa. A formação do professor de Física no contexto do Pibid: os saberes e as relações. 2013. 131 f. Dissertação (Programa de pósgraduação em Ensino de Ciências e Educação Matemática) - Universidade Estadual de Londrina, Londrina, 2013.

FETZNER, Andréa Rosana; SOUZA, Maria Elena Viana. Concepções de conhecimento escolar: potencialidades do Programa Institucional de Bolsa de Iniciação à Docência. Educação e Pesquisa, São Paulo, v. 38, n. 03, p. 683-694, jul./set. 2012.

FUNDAÇÃO COORDENAÇÃO DE APERFEIÇOAMENTO DE PESSOAL DE NÍVEL SUPERIOR (CAPES); FUNDO NACIONAL PARA O DESENVOLVIMENTO DA EDUCAÇÃO (FNDE). Aviso de chamamento público MEC/CAPES/FNDE n. 1/2007. Brasília: Capes, 2007. Disponível em: <http://www.capes.gov.br/images/stories/download/editais/Edital_PIBID.pdf>.

FUNDAÇÃO COORDENAÇÃO DE APERFEIÇOAMENTO DE PESSOAL DE NÍVEL SUPERIOR (CAPES). Edital n. 01/2011. Programa Institucional de Bolsa de Iniciação à Docência. Brasília: Capes, 2011. Disponível em: <http://www.capes.gov.br/images/stories/download/bolsas/Edital_001_PIBID_2011.pdf>. 
. Modelo de relatório de atividades. Brasília: Capes, 2012. Disponível em: $<$ http://www.capes.gov.br/images/stories/download/bolsas/Pibid_ModeloRelatorioAtivi dades-dez12.pdf>.

Portaria n. 96, de 18 de julho de 2013. Regulamento do Programa Institucional de Bolsa de Iniciação à Docência. Brasília: Capes, 2013. Disponível em: $<$ http://www.capes.gov.br/images/stories/download/legislacao/Portaria_096_18jul13_A provaRegulamentoPIBID.pdf>.

. Edital n. 61/2013. Programa Institucional de Bolsa de Iniciação à Docência. Brasília: Capes, 2013. Disponível em: <http://www.capes.gov.br/images/stories/download/editais/Edital_061_2013_PIBID.pdf>.

- Manual de Orientações para Execução de Despesas do Pibid Elaboração do Plano de Trabalho. Brasília: Capes, 2014. Disponível em: <http://www.capes.gov.br/images/stories/download/bolsas/Relatorio-Bolsas-Pibid-032014.pdf $>$.

2014. . Relatório de geração de pagamento de bolsas 03/2014. Brasília: Capes, $<$ http://www.capes.gov.br/images/stories/download/bolsas/Relatorio-Bolsas-Pibid-032014.pdf>.

. Diretoria de Formação de Professores da Educação Básica - Relatório de gestão 2009-2013. Brasília: Capes, 2013. Disponível em: $<$ http://www.capes.gov.br/images/stories/download/bolsas/2562014-relatrorio-DEB2013-web.pdf>.

GARCIA, Lucas. Venício. A formação docente nos subprojetos química do programa institucional de bolsa de iniciação à docência. 2013. 206 f. Dissertação (Mestrado em Química) - Universidade Federal de Uberlândia, Uberlândia, 2013.

GATTI, Bernadete Angelina. Formação de professores no Brasil: características e problemas. Educação e Sociedade, Campinas, v. 31, n. 113, p.1355-1379, out./dez. 2010. Disponível em: <http://www.scielo.br/pdf/es/v31n113/16.pdf>.

; NUNES, Marina Muniz Rossa (Org.). Formação de professores para o Ensino Fundamental: um estudo dos currículos das licenciaturas em pedagogia, língua portuguesa, matemática e ciências biológicas. São Paulo: F. Carlos Chagas, $2009 . \quad$ Disponível em: <http://www.fcc.org.br/biblioteca/publicacoes/textos_fcc/arquivos/1463/arquivoAnexad o.pdf>.

. Educação, escola e formação de professores: políticas e impasses. Educar em Revista, Curitiba, n. 50, p. 51-67, out./dez. 2013. Disponível em <http://www.scielo.br/pdf/er/n50/n50a05.pdf>. 
GAUTHIER, Clermont. Da pedagogia tradicional à pedagogia nova. In: GAUTHIER, Clermont; TARDIF, Maurice (orgs.). A pedagogia: teorias e práticas da Antiguidade aos nossos dias. Tradução de Lucy Magalhães. cap. 6. Petrópolis: Vozes, 2010.

INSTITUTO NACIONAL DE ESTUDOS E PESQUISAS EDUCACIONAIS ANÍSIO TEIXEIRA (Inep). Estudo exploratório sobre o professor brasileiro com base nos resultados do Censo Escolar da Educação Básica 2007. Brasília: Inep, 2009. Disponível em: <http://download.inep.gov.br/download/censo/2009/Estudo_Professor_1.pdf>.

JANNUZZI, Paulo de Martino. Indicadores sociais no Brasil: conceitos, fonte de dados e aplicações. Campinas: Alínea, 2001.

JARDILINO, José Rubens Lima. Políticas de Formação de Professores em conflito com o currículo: Estágio Supervisionado e PIBID. Educação (UFSM), Santa Maria, v. 39, p. 353-366, 2014.

KÖHLER, Rita de Cassia Oliveira. A química da estética capilar como temática no ensino da química e na capacitação dos profissionais de beleza. 2011. $113 \mathrm{f}$. Dissertação (Mestrado em Educação em Ciências: Química da Vida) - Universidade Federal de Santa Maria, Santa Maria, 2011.

LAPO, Flavinês Rebolo.; BUENO, Belmira Oliveira. Professores, desencanto com a profissão e abandono do magistério. Cadernos de Pesquisa, São Paulo, n.118, p.6588, mar. 2003.

LEME, Luciana França. Atratividade do magistério para a educação básica: um estudo com ingressantes de cursos superiores da Universidade de São Paulo. 2012. 2010 f. Dissertação (Mestrado em Educação) - Faculdade de Educação, Universidade de São Paulo, São Paulo, 2012.

LIMA, Fernanda Bartoly Gonçalves de; SILVA, Kátia Augusta Curado Pinheiro Cordeiro da. As licenciaturas nos institutos federais: concepções e pressupostos. In: IV ENCONTRO ESTADUAL DE DIDÁTICA E PRÁTICA DE ENSINO (Endipe), Goiânia, 2011.

MARTINS, Maria Márcia Melo de Castro. Saberes pedagógicos e o desenvolvimento de metodologias de ensino de biologia: o Pibid como elemento de construção. 2013. 229 f. Dissertação (Programa de Pós-graduação em Ensino de Ciências e Matemática) - Universidade Federal do Ceará, Fortaleza, 2013.

MELLO, Marisol Barenco de. Inclusão ou diálogos na escola: uma experiência de formação de professoras. Revista Teias, Rio de Janeiro, v. 12, n. 24, p. 57-66, jan.abr. 2011. 
MERTENS, Donna M.; WILSON, Amy. T. Program Evaluation Theory and Practice - A Comprehensive Guide. 1st. ed. New York: The Guilford Press, 2012.

MIZALA, Alejandra; ÑOPO, Hugo. Measuring the Relative Pay of Latin American School Teachers at the turn of the 20th Century. Peruvian Economic Association, n. 2014-15, Lima, Peru, 2014.2 Disponível em: <http://EconPapers.repec.org/RePEc:apc:wpaper:2014-015>.

MOURA, Eliton Meireles de. O Programa Institucional de Bolsa de Iniciação à Docência - Pibid na formação inicial de professores de Matemática. 2013. $197 \mathrm{f}$. Dissertação (Mestrado em Educação) - Programa de Pós-Graduação em Educação, Universidade Federal de Uberlândia, Uberlândia, 2014.

MORICONI, Gabriela Miranda. Os professores públicos são mal remunerados nas escolas brasileiras? Uma análise da atratividade da carreira do magistério sob 0 aspecto da remuneração. $86 \mathrm{f}$. Dissertação (Mestrado em Administração Pública e Governo) - Escola de Administração de Empresas de São Paulo, Fundação Getúlio Vargas, São Paulo, 2008.

ORGANISATION FOR ECONOMIC CO-OPERATION AND DEVELOPMENT (OECD). Teachers matter: Attracting, Developing and Retaining Effective Teachers. OECD: Paris, 2005.

PIMENTA, Selma Garrido; LIMA, Maria Socorro Lucena. Estágio e docência: diferentes concepções. Revista Poíesis, Goiânia, n. 3 e 4, p. 5-24, 2005-2006.

PINTO, José Marcelino Rezende. Remuneração adequada do professor: desafio à educação brasileira. Revista Retratos da Escola, Brasília, v. 3, n. 4, p. 51-67, jan.jun./2009.

PONTE, João Pedro da. Da formação ao desenvolvimento profissional. Actas do ProfMat $98 . \quad$ Lisboa: APM. $\quad$ Disponível em http://www.educ.fc.ul.pt/docentes/jponte/DOCS-PT\%5C98-Profmat.doc,

RAIZER, Paula Barros. Crenças sobre a língua espanhola para estudantes brasileiros do ensino fundamental: características e uma proposta de encaminhamento. 2013. 109 f. Dissertação (Mestrado em Linguística) - Universidade Federal de São Carlos, São Paulo, 2013.

ROCHA, Cláudio César Torquato. Saberes da docência aprendidos no PIBID: um estudo com futuros professores de Sociologia. 2013. 163 f. Dissertação (Programa de mestrado acadêmico em Educação) - Universidade Federal do Ceará, Fortaleza, 2013.

RISTOFF, Dilvo Ilvo; Bianchetti, Lucídio. A Pós-graduação e suas interlocuções com a educação básica. Avaliação (Unicamp), v. 17, p. 767-824, 2012. 
RUIZ, Antonio Ibanez; RAMOS, Morzart Neves; HINGEL, Murílio. Escassez de professores no Ensino Médio: propostas estruturais e emergenciais. Brasília: MEC/CNE/CEB, 2007.

SAVIANI, Demerval. Formação de professores: aspectos históricos e teóricos do problema no contexto brasileiro. Revista Brasileira de Educação, Rio de Janeiro, v. 14, n. 40, p. 143-155, 2009. Disponível em: <http://www.scielo.br/pdf/rbedu/v14n40/v14n40a12.pdf>.

SECCHI, L. Políticas Públicas - Conceitos, Esquema de Análise e casos Práticos. 2.ed. São Paulo: Cengage Learning, 2011.

SCHEIBE, Leda. Valorização e formação dos professores para a educação básica: questões desafiadoras para um novo plano nacional de educação. Campinas, SP: Educação e Sociedade, v. 31, n. 112, p. 981-1000, jul.-set. 2010.

SOARES, Adriany Thatcher C.; SIQUEIRA, Alexandra Q.; MALAQUIAS, Vera Lúcia Santos M. Ensinar-aprender na escola: a experiência do Pibid no município de Salvador/BA. Revista Sulamericana de Filosofia e Educação, Brasília, n. 16, maioout/2011, p. 109-119.

SOARES, Olavo Pereira. Os currículos para o ensino de história: entre a formação, o prescrito e o praticado. Antíteses, Londrina, v. 5, n. 10, p. 613-634, jul./dez. 2012.

SOUSA, Isabela Mascarenhas Antoniutti de. Aprendendo a ser professor: a prática no PIBID como possibilidade de mobilização e [re]elaboração de saberes sobre alfabetização. 2013. 201 f. Tese (Doutorado em Educação) - Faculdade de Educação, Pontifícia Universidade Católica do Rio Grande do Sul, Porto Alegre, 2013.

SOUZA, Marta Gresechen Paiter Luzia de. Aprendizagem(ns) para mudar totalidade(s): uma experiência de formação colaborativa de professores(as) de língua inglesa. 2013. 103 p. Dissertação (Mestrado em Estudos da Linguagem) - Programa de Pós-Graduação em Estudos da Linguagem, Universidade Estadual de Londrina, Londrina, 2013.

STAKE, Robert E. Qualitative research: studying how things work. New York: The Gilford Press, 2010.

STANZANI, Enio de Lorena; BROIETTI, Fabiele Cristiane Dias; PASSOS, Marinez Meneghello. As Contribuições do PIBID ao Processo de Formação Inicial de Professores de Química. Química Nova na Escola, São Paulo, v. 34, n. 4, p. 210 219, nov. 2012. Disponível em < http://qnesc.sbq.org.br/online/qnesc34_4/07-PIBID68-12.pdf>.

STANZANI, Enio de Lorena. O papel do Pibid na formação inicial de professores de Química na Universidade Estadual de Londrina. 2012. 87 p. Dissertação (Mestrado em Ensino de Ciências e Educação Matemática) - Programa de Pós- 
graduação em Ensino de Ciências e Educação Matemática, Universidade Estadual de Londrina, Londrina, 2013.

TANURI, Leonor Maria. História da formação de professores. Revista Brasileira de Educação, Rio de Janeiro, n. 14, maio/jun./jul./ago. 2006. Disponível em: $<$ http://www.scielo.br/pdf/rbedu/n14/n14a05>.

TARTUCE, Gisela Lobo B. P.; NUNES, Marina M. R.; ALMEIDA, Priscila Cristina A. Alunos do ensino médio e atratividade da carreira docente no Brasil. Cadernos de Pesquisa, São Paulo, v.40, n. 140, p. 445-477, maio/ago. 2010. Disponível em <http://www.scielo.br/pdf/cp/v40n140/a0840140.pdf>.

TEIXEIRA, Anísio. Valores proclamados e valores reais nas instituições escolares brasileiras. Revista Brasileira de Estudos Pedagógicos, Rio de Janeiro, v.37, n.86, p. 59-79, abr.-jun. 1962.

TINTI, Douglas da Silva. PIBID: um estudo sobre suas contribuições para o processo formativo de alunos de Licenciatura em Matemática da PUC-SP. 2012. $148 \mathrm{f}$. Dissertação (Mestrado em Educação Matemática) - Programa de Estudos PósGraduados em Educação Matemática, Pontifícia Universidade Católica de São Paulo, São Paulo, 2012.

UNB. Proposta n. 128575. Projeto institucional do Pibid UnB. Subprojeto de Física. Brasília: UnB, 2013. (Documento interno).

UNB. Instituto de Física. Pibid 2014 - Subprojeto Física UnB. Brasília: UnB, 2014. (Documento interno).

YIN, Robert K. Case study research: design and methods. 3rd. ed. Thousand Oaks: Sage Publications, 2003. 